\title{
A STUDY ON THE POTENTIAL FOR SUSTAINABLE WASTE MANAGEMENT IN THE GREATER TORONTO AREA
}

\author{
by \\ MD SHAMSUL ALAM, MEng, BSc \\ Master of water Resources Engineering
}

Bangladesh University of Engineering and Technology, Dhaka, Bangladesh, 2006

B. Sc. Agricultural Engineering (Hons.)

Bangladesh Agricultural University, Mymensingh, Bangladesh, 1975

\author{
A Project \\ presented to Ryerson University \\ in partial fulfillment of the \\ requirements for the degree of \\ Master of Engineering \\ in the Program of \\ Civil Engineering
}

Toronto, Ontario, Canada, 2010

CMD SHAMSUL ALAM, 2010 


\section{Author's Declaration}

I hereby declare that I am the sole authority of this project.

I authorize Ryerson University to lend this project to other institutions or individuals for the purpose of scholarly research.

I further authorize Ryerson University to reproduce this project by photocopying or by other means, in total or in part, at the request of other institutions or individuals for the purpose of scholarly research. 


\title{
A STUDY ON THE POTENTIAL FOR SUSTAINABLE WASTE MANAGEMENT IN THE GREATER TORONTO AREA
}

\author{
Master of Engineering, 2010 \\ MD SHAMSUL ALAM \\ Civil Engineering Program \\ Ryerson University
}

\begin{abstract}
Performance of the residential waste management practices in the Greater Toronto Area (GTA) was studied. The study encompassed identification of waste management practices and analysis of data concerning different management options followed by the Regional Municipalities of Durham, Halton, Peel, York and the City of Toronto during 2002 to 2008. Historically, wastes from the GTA were disposed of in the landfills. Majority wastes from the GTA were exported to Michigan under a contract which is going to be expired at the end of 2010. Residents already opposed to accept new landfills. Toxic emissions from the incinerators are also of great concern to them. Integrated waste management system comprising source reduction, recycling and reuse, diversion through green bin SSO program and the aerobic/anaerobic processing of organic waste treatment can be considered to succeed in achieving the most effective and sustainable solution to the residential waste management problems in the GTA.
\end{abstract}




\section{Acknowledgements}

The author acknowledges his indebtedness and sincere gratitude to his supervisor Dr. Grace K. Luk, PEng, Professor, Department of Civil Engineering, Ryerson University for her continuous guidance, assistance and spirited encouragement through the entire course of this project work.

The author is highly thankful and grateful to the staffs/officers of the Regional Municipality of Durham, Regional Municipality of Halton, Regional Municipality of Peel, Regional Municipality of York and the City of Toronto for their whole hearted support and co-operation in providing me with the required waste management reports / data for the years from 2002-2008.

The author is also grateful to Suzette Giles, Data Librarian, Ryerson University for her sincere co-operation in finding some important web sites related to data on waste management.

The author wishes to express his sincere thanks to Dr. Li He, Assistant Professor, Department of Civil Engineering, Ryerson University for his valuable suggestions/advice during the course of this project work. 


\section{Table of Contents}

Abstract

Acknowledgements

iv

Table of Contents

List of Figures

List of Abbreviations

xii

CHAPTER 1 INTRODUCTION

1.1 General

1.2 Background

1.3 Objectives

CHAPTER 2 LITERATURE REVIEW

2.1 Greater Toronto Area

2.1.1 Regional Municipality of Durham

2.1.2 Regional Municipality of Halton

2.1.3 Regional Municipality of Peel

2.1.4 Regional Municipality of York

2.2 Previous Studies $\quad 10$

2.2.1 Municipal Solid Waste Management Overview

2.22 Alternative Management Options

2.2.3 Life Cycle Inventory/ Life Cycle Assessment

2.2.4 Integrated Waste Management

3.1 Study Area and Duration

3.2 Selection of Indicators

3.2.1 Total quantity of waste disposed of in a year

3.2.2 Total quantity of waste diverted in a year

3.2.3Percentage of waste diverted in a year

3.2.4 Percentage composition of diverted waste

3.2.5 Total quantity of waste managed in a year

3.2.6 Per capita waste generated in a year 
3.4 Data Analysis

$\begin{array}{lll}\text { CHAPTER } 4 \text { ANALYSIS AND RESULTS } & 20\end{array}$

$\begin{array}{ll}4.1 \text { General } & 20\end{array}$

4.2 Regional Municipality of Durham 20

4.2.1 Waste Management in the Year $2002 \quad 20$

4.2.1.1 Disposal of Residential Garbage $\quad 21$

4.2.1.2 Waste Diversion $\quad 21$

4.2.1.3 Population and Quantity of Waste Managed $\quad 24$

4.2.2 Temporal Trend from 2002-2008 25

4.2.2.1 Waste Disposal 25

4.2.2.2 Waste Diversion $\quad 26$

$\begin{array}{ll}\text { 4.2.2.3 Diverted Waste Composition } & 27\end{array}$

4.2.2.4 Population and Waste Generation $\quad 30$

4.2.2.5 Waste Generations Per Capita 31

4.3 Regional Municipality of Halton 32

4.3.1 Waste Management in the Year 2002

4.3.1.1 Disposal of Garbage $\quad 32$

4.3.1.2 Waste Diversion 33

4.3.1.3 Population and Quantity of Waste Managed 36

4.3.2 Temporal Trend from 2002-2008 37

4.3.2.1 Waste Disposal $\quad 37$

4.3.2.2 Waste Diversion $\quad 38$

4.3.2.3 Diverted Waste Composition $\quad 39$

4.3.2.4 Population and Waste Generation $\quad 43$

4.3.2.5 Waste Generations Per Capita 43

4.4 Regional Municipality of Peel 44

4.4.1 Waste Management in the Year 2002

4.4.1.1 Disposal of Garbage $\quad 44$

4.4.1.2 Waste Diversion $\quad 45$

4.4.1.3 Population and Quantity of Waste Managed 48

4.4.2 Temporal Trend from 2002-2008 48

$\begin{array}{ll}\text { 4.4.2.1 Waste Disposal } & 48\end{array}$ 
4.4.2.2 Waste Diversion $\quad 49$

4.4.2.3 Diverted Waste Composition 50

4.4.2.4 Population and Waste Generation $\quad 54$

4.4.2.5 Waste Generations Per Capita

4.5 Regional Municipality of York

4.5.1 Waste Management in the Year 2002

4.5.1.1 Disposal of Waste $\quad 56$

4.5.1.2 Waste Diversion $\quad 56$

4.5.1.3 Population and Quantity of Waste Managed 59

4.5.2 Temporal Trend from 2002-2008 59

4.5.2.1 Waste Disposal $\quad 59$

4.5.2.2 Waste Diversion $\quad 60$

4.5.2.3 Diverted Waste Composition $\quad 61$

4.5.2.4 Population and Waste Generation $\quad 65$

4.5.2.5 Waste Generations Per Capita $\quad 65$

4.6 City of Toronto $\quad 66$

4.6.1 Waste Management in the Year 2002

4.6.1.1 Disposal of Residential Garbage $\quad 67$

$\begin{array}{ll}\text { 4.6.1.2 Waste Diversion } & 67\end{array}$

4.6.1.3 Population and Quantity of Waste Managed 70

4.6.2 Temporal Trend from 2002-2008 71

4.6.2.1 Waste Disposal

$\begin{array}{ll}\text { 4.6.2.2 Waste Diversion } & 72\end{array}$

4.6.2.3 Diverted Waste Composition $\quad 73$

4.6.2.4 Fopulation and Waste Generation 76

4.6.2.5 Waste Generations Per Capita $\quad 77$

4.7 Greater Toronto Area Waste Management $\quad 78$

$\begin{array}{ll}\text { 4.7.1 Waste Disposal (2002-2008) } & 78\end{array}$

4.7.2 Waste Diversion in Tonnes (2002-2008) 79

4.7.3 Waste Diversion Percentage (2002-2008) 80

4.7.4 Total Waste Managed (2002-2008) 81

4.7.5 Population Growth (2002-2008) 82 
4.7.6 Waste Generations Per Capita (2002-2008)

4.7.7 Main Findings of Comparison Study 85

4.7.8 Cost Analysis for Solid Waste Management 85

$\begin{array}{lll}\text { CHAPTER } 5 & \text { WASTE MANAGEMENT IN THE GTA }\end{array}$

$\begin{array}{ll}5.1 \text { General } & 89\end{array}$

5.2 Integrated Waste Management in the GTA 90

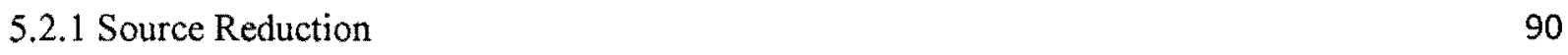

5.2.2 Recycling and Reuse $\quad 92$

$\begin{array}{ll}5.2 .3 \text { Green bin SSO } & 93\end{array}$

5.2.4 Biological Treatment $\quad 94$

5.2.4.1 Aerobic Processing - Composting 94

5.2.4.2 Anaerobic Processing - Bio-energy 96

$\begin{array}{ll}5.2 .5 \text { Incineration } & 97\end{array}$

$\begin{array}{ll}\text { 5.2.6 Landfilling } & 98\end{array}$

$\begin{array}{lrr}\text { CHAPTER } 6 & 101\end{array}$

$\begin{array}{ll}6.1 \text { Conclusions } & 101\end{array}$

$\begin{array}{lr}6.2 \text { Recommendations } & 104\end{array}$

$\begin{array}{ll}\text { REFERENCES } & 106\end{array}$

$\begin{array}{ll}\text { APPENDICES } & 113\end{array}$

$\begin{array}{ll}\text { APPENDIX-A } & 114\end{array}$

$\begin{array}{lr}\text { APPENDIX-B } & 115\end{array}$

$\begin{array}{ll}\text { APPENDIX-C } & 116\end{array}$

$\begin{array}{ll}\text { APPENDIX-D } & 117\end{array}$

$\begin{array}{ll}\text { APPENDIX-E } & 118\end{array}$ 


\section{List of Tables}

Table-4.1 Durham Region 2002 Waste landfilled $\quad 21$

Table-4.2 2002 Residential Waste Diversion $\quad 23$

Table-4. 3 Durham Region 2002 Waste Management 24

Table 4.4 Halton Region 2002 Waste Landfilled 33

Table 4.5 Halton Region 2002 Waste Diversion $\quad 35$

Table 4.6 Halton Region 2002 Waste Management 36

Table 4.7 Peel Region Waste Disposal $\quad 45$

Table 4.8 Region of Peel Waste Diversion $2002 \quad 47$

Table 4.9 Peel Region 2002 Waste Management 48

Table-4.10 York Region 2002 Waste Landfilled 56

Table 4.11 Waste Diversion in $2002 \quad 58$

Table 4.12 York Region 2002 Waste Management $\quad 59$

Table-4.13 2002 Residential Waste Diversion $\quad 69$

Table-4.14 City of Toronto 2002 Waste Management $\quad 70$ 


\section{List of Figures}

Figure 2.1 Greater Toronto Area - - 9

Figure 4.1 Composition of Diverted Waste in $2002 \quad 24$

Figure 4.2 Waste Disposal of Durham Region $\quad 25$

$\begin{array}{ll}\text { Figure 4.3 Waste Diversion of Durham Region } & 26\end{array}$

Figure 4.4 Composition of Diverted Waste in $2003 \quad 27$

Figure 4.5 Composition of Diverted Waste in $2004 \quad 28$

$\begin{array}{ll}\text { Figure 4.6 Composition of Diverted Waste in } 2005 & 28\end{array}$

Figure 4.7 Composition of Diverted Waste in $2006 \quad 29$

$\begin{array}{lr}\text { Figure 4.8 Composition of Diverted Waste in } 2007 & 29\end{array}$

Figure 4.9 Composition of Diverted Waste in 2008

Figure 4.10 Population Growths and Waste Generation 31

Figure 4.11 Waste Generations Per Capita $\quad 32$

Figure 4.12 Composition of Diverted Waste in 2002

Figure 4.13 Waste Disposal of Halton Region $\quad 37$

Figure 4.14 Waste Diversion of Halton Region $\quad 39$

Figure 4.15 Composition of Diverted Waste in $2003 \quad 40$

Figure 4.16 Composition of Diverted Waste in 2004

Figure 4.17 Composition of Diverted Waste in 2005

Figure 4.18 Composition of Diverted Waste in 2006

Figure 4.19 Composition of Diverted Waste in 2007

Figure 4.20 Composition of Diverted Waste in 2008

Figure 4.21 Population Growths and Waste Generation 43

Figure 4.22 Waste Generations Per Capita $\quad 44$

Figure 4.23 Composition of Diverted Waste in 2002

Figure 4.24 Waste Disposal of Peel Region $\quad 49$

Figure 4.25 Waste Diversion of Peel Region $\quad 50$

Figure 4.26 Composition of Diverted Waste in 2003

Figure 4.27 Composition of Diverted Waste in 2004

Figure 4.28 Composition of Diverted Waste in 2005

Figure 4.29 Composition of Diverted Waste in 2006

Figure 4.30 Composition of Diverted Waste in 2007

Figure 4.31 Composition of Diverted Waste in 2008

Figure 4.32 Population Growths and Waste Generation $\quad 54$

Figure 4.33 Waste Generations Per Capita $\quad 55$

Figure 4.34 Composition of Diverted Waste in $2002 \quad 58$

Figure 4.35 Waste Disposal of York Region $\quad 60$

Figure 4.36 Waste Diversion of York Region $\quad 61$ 
Figure 4.37 Composition of Diverted Waste in 2003

Figure 4.38 Composition of Diverted Waste in 2004

Figure 4.39 Composition of Diverted Waste in 2005

Figure 4.40 Composition of Diverted Waste in 2006

Figure 4.41 Composition of Diverted Waste in 2007

Figure 4.42 Composition of Diverted Waste in 2008

Figure 4.43 Population Growths and Waste Generation

Figure 4.44 Waste Generations Per Capita

Figure 4.45 Composition of Diverted Waste in 2002

Figure 4.46 Waste Disposal of the City of Toronto 71

Figure 4.47 Waste Diversion of the City of Toronto 72

Figure 4.48 Composition of Diverted Waste in 2003 73

Figure 4.49 Composition of Diverted Waste in 2004 74

Figure 4.50 Composition of Diverted Waste in 2005 74

Figure 4.51 Composition of Diverted Waste in 2006 75

Figure 4.52 Composition of Diverted Waste in 2007 75

Figure 4.53 Composition of Diverted Waste in 2008 76

Figure 4.54 Population Growths and Waste Generation 77

Figure 4.55 Waste Generations Per Capita 78

Figure 4.56 Waste Disposal in the GTA 79

Figure 4.57 Waste Diversion (Tonnes) in the GTA 80

Figure 4.58 Waste Diversion (\%) in the GTA 81

Figure 4.59 Total Waste Managed in the GTA 82

Figure 4.60 Population Growths in the GTA 83

Figure 4.61 Waste Generations Per Capita in the GTA 84

Figure 4.62 Cost of Solid Waste Collection Per Tonne 86

Figure 4.63 Cost of Solid Waste Diversion Per Tonne 87

Figure 4.64 Cost of Solid Waste Disposal Per Tonne 


\section{List of Abbreviations}

ABR Anaerobic Baffled Reactor

AD Anaerobic Digestion

APC Air Pollution Control

CCME Canadian Council of Ministers of the Environment

EFW Energy from Waste

EPR Extended Producer Responsibility

FSQ Final Storage Quality

GDP Gross Domestic Product

GHG Green House Gas

GTA Greater Toronto Area

GWF Global Worming Factor

HC Home Composting

IC\&I Industrial, Commercial and Institutional

IWA Interim Waste authority

LCI Life Cycle Inventory

LFG Landfill Gas

LTWMS Long Term Waste Management Strategy

MRF Material Recovery Facility

MSW Municipal Solid Waste

OPA Ontario Power Authority

PAC Powered Activated Carbon

PEI Prince Edward Island

RBC Runnymede Borough Council 
SCR Selective Catalytic Reduction

SSO Source Separated Organics

UK United Kingdom

UNFCCC United Nations Framework Convention on Climate Change

USA United States of America

USEPA United States Environmental Protection Agency 


\section{CHAPTER 1}

\section{INTRODUCTION}

\subsection{General}

Problem of solid waste management is a global issue. Increasing waste generation rates due to population growth, changed lifestyles, development and consumption of products that are less biodegradable have led to diverse challenges for waste management in various cities of the world. In most developed countries, public health is no more a major driver of waste management; the current focus is on the optimization of waste management practices with a broader goal of resource conservation (McDougall et al.2001).

Greater Toronto Area (GTA), comprising of Regional Municipalities of Durham, Halton, Peel, York and the City of Toronto is the most populous metropolitan area in Canada as well as the centre of increasing economic/commercial activities and industrial development. Canada is the sweet home for the immigrants and most of them prefer to settle in the GTA. So, GTA is not an exception to facing the challenges of increasing waste and its management problems like the other cities of the developed world.

Integrated system of waste management is already in place in every cities of the GTA. But the choice of waste management options is different among the Regional Municipalities/the City of Toronto. Diversion goals of waste from the landfills are also set differently by the Regional Municipalities/the City of Toronto. But the objective is common, how efficiently to combat the increasing waste problems and to find a successful solution!

Historically, wastes from the GTA were disposed of in the landfills and majority wastes were hauled to Michigan under a contract. The expiry date for the contract is imminent by this time. The Michigan Authority is no longer in a position to accept wastes from the other side of their border beyond the year 2010. Space is not a problem but the strong opposition for acceptance from the residents, compelled the authority to drop the idea of constructing new landfills in the 
GTA. On the other hand, Landfill gas is liable for green house gas (GHG) emissions. But it can be a source of energy/electricity.

Incineration is a popular method of waste disposal around Europe and Japan. But toxic emissions from the incinerators are of concern not only to the communities across the GTA but also to Health Canada as well.

So, effective waste management methods alternative to landfilling and incineration should be the reasonable choice for the GTA.

Increasing source separated organics collection and its treatment is an emerging potential for diverting wastes from disposal. Organic fraction of the residential waste has already proved itself to be a renewable source of energy/electricity.

According to an estimate by the Toronto City summit Alliance, residential waste contributed $36 \%$ to the overall waste volume of the GTA in 2007 . So, residential waste is an important sector to be addressed. This study focuses on the residential waste management problems and potential solutions to achieve a sustainable waste management approach for the years to come.

\subsection{Background}

Once, the environment was thought to be an unlimited sink for consumption of waste materials. People used to throw their wastes indiscriminately here and there that time. In ancient Rome, wastes were either dumped into the river, streets or open pits on the outskirts of the city. Rome was the first civilization that organized a workforce for waste collection in 14 C.E. (vesilind et al., 2002). With the end of the Roman Empire, dumping of waste in the streets became a common practice again.

During the medieval period, discarding wastes in the surface water was practiced in UK. The cause of plague which claimed 25 million European citizens during 1347 to 1352 was attributed to the dumping of wastes in the surface water. An order was issued in 1388 by the English Parliament prohibiting dumping of wastes in to the rivers or water courses adding that refuse 
would be carried away to the selected sites to avoid the nuisance (Wilson, 1977). Garbage cans were introduced in 1408.

As early as 1657 the residents of New Amsterdam (later New York City) were still throwing garbage in the streets and they were prohibited from doing this and the individual homeowner was given the responsibility of maintaining the street clean. Simple dumping platforms were built over the East River for unloading garbage from the city and it continued up to 1872 . Until 1890 s the garbage collection and disposal systems in the US were very poor. Open dumping of waste was practiced in Chicago, St. Louis, Boston and Baltimore. New York City garbage was carried by barges for dumping 25 miles offshore. Simple form of recycling i.e. scouring the streets and trash piles for material of value started in the late 1800 s by enterprising individuals. The first material recovery facility (MRF) was installed in New York in 1898. Intensive urbanization and industrialization of the United States in the latter half of the $19^{\text {th }}$ century caused acute sanitary problems and that is why modern solid waste management programs evolved in the 1890s (Blumberg and gottlieb,1989). 89\% American cities were provided with waste collection system by 1915 and almost all cities availed the waste collection system by 1930 . Various waste management programs such as land disposal, water disposal (including ocean dumping), incineration, reduction or combination of the programs were adopted by the turn of the $20^{\text {th }}$ century.

England and Germany were the pioneers for the development of effective solid waste incinerator. First solid waste incineration was carried out in Nottingham, England in 1874 (Murphy, 1993). Germans developed incinerator next to England in cooperation with English engineers. In the year 1885, USA installed the first incinerator and its wide spread use started by 1910 .

British and Germans developed energy recovery technology from waste incineration and the first incineration facility of that kind was developed in UK in the mid 1890s. 76 incineration facilities were producing electricity in UK by 1912 and 17 more were in operation in other parts of Europe at the same time. An incineration plant for producing electricity from waste was developed as a pilot project in New York in 1905. Only two cities in North America - Westmount, Quebec, and Milwaukee were producing steam from incinerators (Marshall, 1929; Melosi, 2000) during the same time. Due to cheap prices of electricity, "energy from waste" technology failed to get popularity in USA for the next sixty years (Blumberg and Gottlieb, 1989). From late 1960s to 
early 1970 s energy crisis occurred in USA. As an alternative source of electricity generation, "waste to energy" plants and "refuse derived fuel" systems were developed. About 100 plants were installed and a plan for another 200 was under way in the early to mid 1980s in USA.

Up to 1900 s direct dumping of wastes on the land was practiced in USA. Up to 1950 s open pit dumping of wastes was followed as the standard procedure of landfilling. The concept of sanitary landfilling was introduced in 1950s. The sanitary landfilling became the primary method of disposing wastes by 1959 in United States (ASCE, 1959; McBean et al., 1995). Resource Conservation and Recovery Act and its amendments were enacted which resulted in improved sanitary landfill design. For reducing infiltration of precipitation, caps of clays or other impermeable materials such as high density polyethylene were used; to prevent leachate leaking, bottom liners made of similar materials were adopted; leachate collection system and gas collection system were installed, and monitoring of ground water quality was also introduced. Even after this advancement in technology, groundwater contamination became a concern to landfills. According to an estimate by US EPA, more than $75 \%$ of landfills were contaminating groundwater (Lee and Jones, 1991). Siting restrictions came in to effect which controlled installation of landfills. The number of landfills dropped from 20,000 in 1979 to 2,216 in 1999 substantially (US EPA, 2001a).

Since 1954, Canada has been using landfills for waste disposal. About 52 landfills were in use until 2006. In 1974 the first incinerator was commissioned in Canada. By the year 1995, a total of seven incinerators each with a capacity of more than 25 tonnes per day were commissioned in Canada. Location of the incinerator facilities are: one in British Columbia, one in Alberta, one in Ontario, three in Quebec and one in Prince Edward Island (PEI).

In 1985, in the Regional Municipality of Durham, solid waste disposal was carried out by four regionally operated landfill sites, two privately owned landfill operations, and Metropolitan Toronto's Brock West landfill. In addition to landfill disposal, a number of recycling groups operated in Durham. In 1983, the majority of York region's waste was disposed of at the city of Toronto's Keele Valley Landfill Site located in Vaughn within York boundaries. Toronto had a landfill crisis looming for 10 to 15 years and participated in a series of landfill site search possesses since the mid 1980s. Britannia Sanitary landfill Site located in Mississauga was the 
primary landfill site for the Region of Peel since 1980s. Halton Waste Management Site began operating in 1992 with a planned life span of 20 years.

In 1991, the Interim Waste Authority Ltd. (IWA) was created to find suitable long-term landfill capacity for the GTA. The Provincial Government announced that three long-term landfill sites for the GTA would be located in Durham, Peel, and Metro Toronto/York Regions. Long time and large amount of money were expended on this siting effort but in response to intense public opposition, this landfill siting exercise was abandoned.

Disposal of waste turned to an acute problem along with the closure of the Keele Valley Landfill Site and Britannia Sanitary landfill Site. Since then, i.e. 2002, majority wastes from the GTA were started hauling to Michigan under a contract.

The grave concern of the greenhouse gases was recognized by the United Nations Framework Convention on Climate Change (UNFCCC). In December 1997, Canada, along with 160 other countries, completed negotiations of the Kyoto Protocol under the United Nations Framework Convention on Climate Change (UNFCCC). This Protocol included reduction targets and a timetable for six greenhouse gases. The third conference of the parties to the UNFCCC resulted in Kyoto Protocol 1997. Canada signed the Kyoto Protocol on 29 April 1998 and ratified it on 17 December 2002. Upon ratification, Canada is committed to greenhouse gas reduction of 6 percent below 1990 levels in the period 2008-2012. In the waste sector, landfill gas capture and destruction (flaring or utilization) has been singled out as making a potentially significant contribution to meeting this target. Domestic greenhouse gas emission trading, or carbon trading, as a result of landfill gas capture and combustion is one tool that can be used to help meet the goal of reducing greenhouse gas emissions (Environment Canada).

$\mathrm{CH}_{4}$ emissions from MSW landfills increased by $18 \%$ between 1990 and 2006, despite an increase in landfill gas capture and combustion of 50\% over the same period. Approximately 314 $\mathrm{kt}$ of $\mathrm{CH}_{4}$ (or $6594 \mathrm{kt} \mathrm{CO}_{2}$ eq) were captured by the 52 landfill gas collection systems operating in Canada (Environment Canada 2007). Of the total amount of $\mathrm{CH}_{4}$ collected, $51 \%$ (159 kt) was utilized for various energy purposes and 49\% (155 kt) was flared. Eight sites utilized the captured $\mathrm{CH}_{4}, 31$ sites flared the captured $\mathrm{CH}_{4}$, and 13 sites utilized and flared the captured $\mathrm{CH}_{4}$. So, there is scope for utilizing further $49 \%$ captured $\mathrm{CH}_{4}$ for various energy purposes. 
A serious electricity supply-demand situation is prevailing across the Province of Ontario. According to an estimate of the Ontario Power Authority (OPA), the demand will exceed supply by 2014 , and the gap between supply and demand will be greater than 10,000 megawatts (MW) by 2025 . Ontario is in need of rebuilding, conserving or replacing a generation capacity of 25,000 megawatts over the next 20 years. Landfill gas/biogas as well as organic waste is considered to be the renewable energy generation sources by the Ontario Power Authority.

In 2012 the Kyoto Protocol to prevent climate changes and global warming is going to run out. To keep the process on line, the Copenhagen Summit 2009 on Climate Change held between 7 December and 18 was very important. In that summit the climate changes issue was highly recognised and the concern about reducing GHG emissions to keep any temperature increases to below $2^{\circ} \mathrm{C}$ was pronounced.

\subsection{Objectives}

1) To quantify the residential waste generated in the Greater Toronto Area

2) To study about the waste management practices and the level of its performance

3) To suggest the suitable/potential options to be integrated to enhance the prevailing waste management practices to a sustainable system. 


\section{CHAPTER 2}

\section{LITERATURE REVIEW}

\subsection{Greater Toronto Area}

The Greater Toronto Area (GTA) comprises of four Regional Municipalities and the City of Toronto (Figure 2.1). Four Regional Municipalities are Durham, Halton, Peel and York. The GTA is larger than Prince Edward Island and bear a different identification from the other provinces.

The term GTA first appeared in a report on the municipal governance restructuring in the region in the mid-1990s and since then it has been widely in use. The GTA forms a part of the inner ring of the renowned Greater Golden Horseshoe and is a designated provincial planning area in the Southern Ontario.

Total area occupied by the G TA is $7,125 \mathrm{~km}^{2}(2,751 \mathrm{sq} \mathrm{mi})$. It has got an excellent location which is on the north of Lake Ontario, to the west of Kawartha Lakes, to the east of the Niagara Escarpment and to the south of Lake Simcoe. It has owned a natural ecosystem known as the Greater Toronto Bioregion. Large urban forests and farmland along with a number of designated parks and ravines is a distinctive feature of the GTA.

Greater Toronto Area is the third largest financial centre in North America, functioning as a centre for distribution, commercial, financial and economic activities. About 20\% national GDP is earned by the GTA. More than 100,000 companies are doing businesses in the GTA and about $40 \%$ Canadian business headquarters are housed in here.

\subsubsection{Regional Municipality of Durham}

The regional Municipality of Durham is a part of the Greater Toronto Area. Durham Region comprises of the Cities of Oshawa and Pickering; the Towns of Ajax and Whitby; the Municipality of Clarington; and the Townships of Brock, Scugog and Uxbridge (Figure 2.1). The 
Regional head quarter is located at Whitby. The Region has the largest area of 2523.15 square kilometres (974.2 square miles) in the GTA stretching from Lake Ontario in the south to Lake Simcoe in the north.

\subsubsection{Regional Municipality of Halton}

The Regional Municipality of Halton is a part of the Greater Toronto Area. It is located in the southwest part of the GTA. Halton Region comprises of the City of Burlington, and the Towns of Oakville, Milton and Halton Hills (Figure 2.1). The Regional head quarter is located in Oakville. The Region has an area of $967.17 \mathrm{~km}^{2}$ (373.4 sq mi) stretching from Lake Ontario in the south to Lake Simcoe in the north. According to area occupancy, it ranks $4^{\text {th }}$ in the GTA.

\subsubsection{Regional Municipality of Peel}

The Regional Municipality of Peel is a part of the Greater Toronto Area. It is located between the Regional Municipality of Halton and the City of Toronto in the inner ring of the Golden Horseshoe. The Region has an area of $1,241.99 \mathrm{~km}^{2}$ (479.54 sq mi). Peel Region comprises of the Cities of Brampton and Mississauga and the Town of Caledon (Figure 2.1). According to area occupancy, it ranks $3 \mathrm{rd}$ in the GTA.

\subsubsection{Regional Municipality of York}

The Regional Municipality of York is a part of the Greater Toronto Area and the inner ring of Golden Horseshoe. It stretches from Lake Simcoe on the north to the City of Toronto on the south. The Region has an area of $1,761.84 \mathrm{~km}^{2}$ (680.25 sq mi). York Region comprises of the Town of Aurora, Town of East Gwillimbury, Town of Georgina, Township of King, Town of Markham, Town of Newmarket, Town of Richmond Hill, City of Vaughan and the Town of Whitchurch-Stouffville (Figure 2.1). According to area occupancy, it ranks 2nd in the GTA. 


\subsubsection{City of Toronto}

The City of Toronto is a part of the Greater Toronto Area. Toronto is at the heart of the GTA and located at the north-western shore of Lake Ontario (Figure 2.1). It is the fifth most populous City in North America. Toronto occupies the smallest area of $630 \mathrm{~km}^{2}$ (243.2 sq mi) with a maximum north-south distance of $21 \mathrm{~km}$ (13 miles) and a maximum east-west distance of $43 \mathrm{~km}$ ( 27 miles). It has 46km (29 miles) waterfront shoreline on the north-western shore of Lake Ontario. Toronto is usually considered as the financial capital of Canada. According to area occupancy, it ranks 5 th in the GTA.

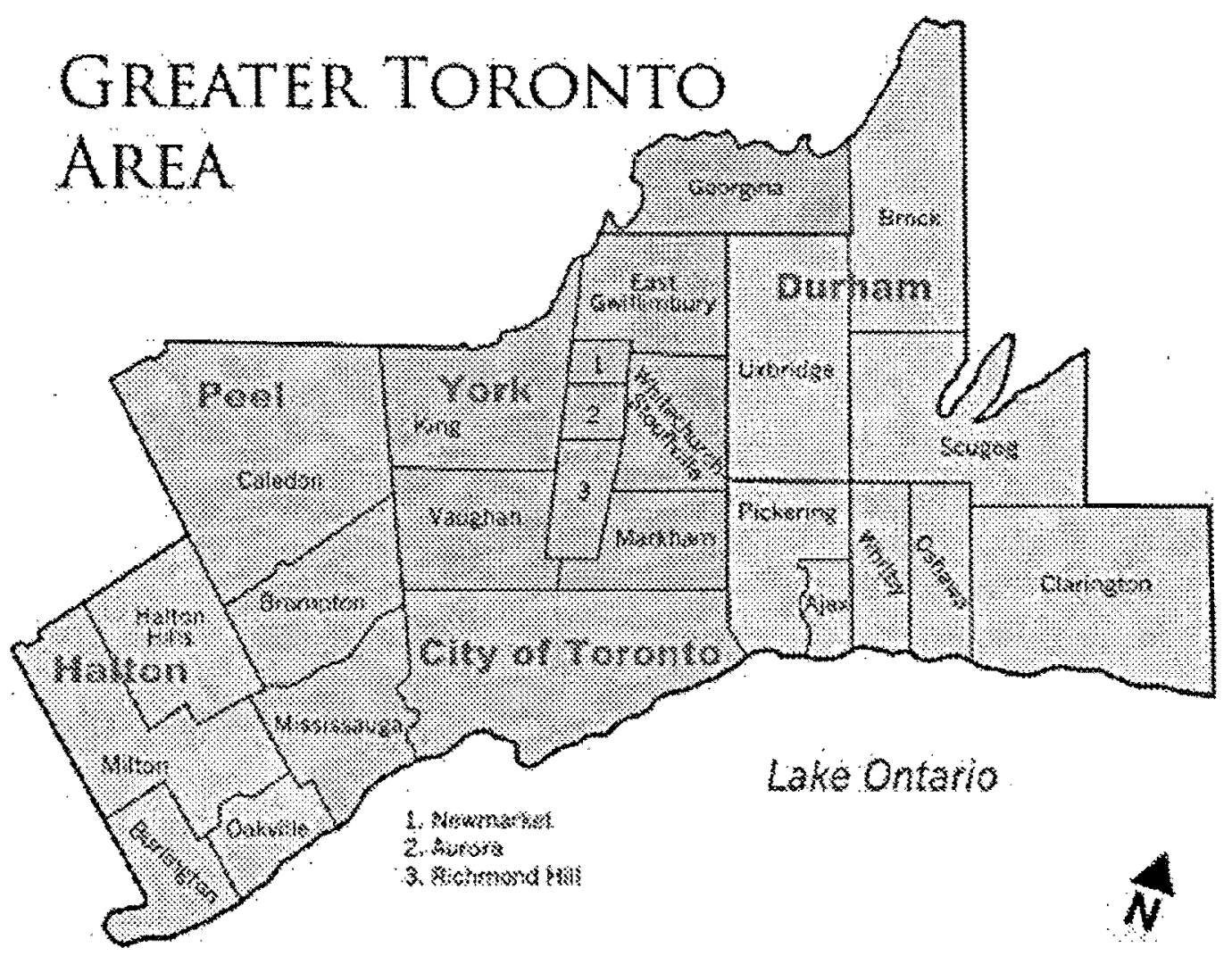

Figure 2.1 Greater Toronto Area 


\subsection{Previous Studies}

\subsubsection{Municipal Solid Waste Management Overview}

Papachristou et al. (2009) conducted a study on the quantity and the characteristics of the municipal solid waste generated in Thessaloniki, the second largest city of Greece in order to help establish an integrated waste management system compatible with the European Union - 15 countries. 20 years investigation at the landfill of Thessaloniki using statistically acceptable practices for sampling and hand sorting resulted in an outcome of great increase in the incoming quantities during the last years and a significant increase of the per capita generation along with a significant change in the composition, demonstrated mainly by a decrease in organic fraction followed by an increase of packaging materials (paper and plastic).

Calabro, P.S. (2009) carried out a study on the effect of separate collection on greenhouse gas emissions from municipal solid waste in Italy which revealed separate collection in combination with the adoption of Best Available Technologies (i.e. biogas recovery and exploitation system in landfills and energy recovery system in Waste to Energy plants) can not only significantly reduce greenhouse gas emissions but, in certain cases, can also make the overall process a carbon sink.

\subsubsection{Alternative Management Options}

Ayalon et al. (2001) carried out a study on the effect of greenhouse gas emissions from different waste management systems in Israel and suggested aerobic composting of degradable organic components to be the most cost effective and time consuming treatment method for greenhouse gas mitigation.

Warith, M. (2002) carried out an experiment on the effect of solid waste size, leachate recirculation and nutrient balance on the rate of municipal solid waste (MSW) biodegradation in a full-scale bioreactor landfill site in Nepean, Ontario, Canada which exhibited a very positive 
effect of small size solid waste including all other factors under consideration to achieve a higher rate of biodegradation and a high waste volume reduction in a relatively short duration with an indication of potential expansion of landfill life thereby decreasing the cost of long term monitoring.

Mbuligwe et al. (2004) carried out a study on the feasibility of Taka (waste) Gas Project involving anaerobic digestion and composting of organic solid waste from Dar es Salam city for producing biogas and using it for generating electricity and suggested for an expected total electricity generation of $5.18 \mathrm{MWh} / \mathrm{d}$ with the possibility of sharing $4.91 \mathrm{MWh} / \mathrm{d}$ to the national grid while the remainder for the internal use of the project.

Warith et al. (2005) carried out an investigation on the effects of leachate recirculation rate on the anaerobic biodegradation of municipal solid waste (MSW) in six simulated bioreactor landfill models which resulted in the reduction of waste stabilization time and enhancement of methane gas production with an indication of potential expansion of landfill life thereby decreasing the cost of long term monitoring.

Chang et al. (2005) conducted a research on cost minimization using optimization model for the integrated solid waste management program of the city of Greensboro, North Carolina. The research carefully included collection, processing, operation and maintenance, and monitoring and regulatory costs for each alternative. The model result indicated a practical and beneficial outcome of implementing incineration, and increasing recycling and composting programs, even though incineration increased costs.

Benson et al. (2006) analyzed five landfills to provide a perspective of current practice and technical issues that differentiate bioreactor in North America from conventional landfills. The study group suggested larger settlements and faster occurrence in bioreactors landfills with leachate recirculation than the conventional landfills resulting in better use of permitted air space during landfill operations with a reduction of maintenance and operational problem after closure.

Malakahmad et al. (2008) performed an experiment in Malaysia to identify the optimum efficiency of Anaerobic Baffled Rector (ABR) for the production of biogas from kitchen waste and observed an output of $74.1 \%$ methane gas from the combination of $75 \%$ kitchen waste and 
$25 \%$ activated sewage sludge with the potential for using methane as an energy source and the sludge in the reactor for future use in composting.

Smith et al. (2009) carried out a 3-yr research program on home composting (HC) in the west London area of Runnymede Borough Council (RBC), Surrey, UK involving a quantitative assessment of the potential diversion of household biodegradable waste from landfill disposal, waste biodegradation processes in small-scale composters, bioaerosol emissions, vector attraction and the end-use of the compost. Research results showed $20 \%$ diversion potential of HC through which $20 \%$ of the biodegradable household waste stream could be diverted from landfill disposal.

Lou et al. (2009) performed a review on the impact of landfilling and composting on greenhouse gas emissions taking into account streamline life cycle activities and the decomposition process and suggested greenhouse gas emissions from waste decomposition as being greatly higher for landfills than composting.

Karagiannidis et al. (2009) performed a multi-criteria analysis exercise implementing electre III for comparing and ranking 5 selected alternative anaerobic digestion technologies suitable for treating the organic fraction of municipal solid waste for potential application in Hellenic islands. The performed multi-criteria approach was found to be a practical and feasible method for the integrated assessment and ranking of anaerobic digestion technologies by also considering different view points and other uncertainties of the decision making process.

Valencia et al. (2009) conducted an experiment to determine the feasibility to achieve Final Storage Quality (FSQ) status (Waste Acceptance Criteria of the European Landfill Directive) of residues in a pilot scale bioreactor landfill. The results of the leaching test were very encouraging due to their proximity to achieving the proposed stringent FSQ criterion after 2 years of operation. 


\subsubsection{Life Cycle Inventory/Life Cycle Assessment}

Ngnikam et al. (2001) performed a Life Cycle Inventory of four municipal solid waste (MSW) management systems in the town of Yaounde, Cameroon. Four management systems were: 1) traditional collection and landfill disposal, 2) collection of biogas in the landfill and generation of electricity, 3) centralised composting, and 4) anaerobic digestion. The Life Cycle Inventory analysis proved landfilling with biogas collection (50 or 70\%) and electricity generation as the most effective one to reduce GHG emissions both at the environmental and economic level at the context of Yaounde.

Cabaraban et al. (2008) carried out a Life Cycle Inventory (LCI) model based assessment on the potential impacts associated with aerobic in-vessel composting and bioreactor landfilling and concluded, bioreactor landfiling as a favourable option over in-vessel composting with regard to cost, overall energy use, and airborne and water borne emissions.

Chen and Lin (2008) carried out a study using the Life Cycle Inventory Model with global warming indicator GHGs as the variable emitted from waste management practices in Taipei city. The study revealed recycling as the most effective method for reducing GHG emissions from kitchen food waste while using as swine food.

Gentil et al. (2009) performed an investigation on the global warming factor (GWF; $\mathrm{CO}_{2}$ eq.tonne $\mathrm{e}^{-1}$ waste) performance of municipal waste management for six representative European Member States: Denmark, France, Germany, Greece, Poland and the United Kingdom. The study integrated European waste statistical data for 2007 in a life cycle assessment modeling perspective. The study revealed achievement of significant GWF benefit due to high level of energy and material recovery substituting fossil energy and raw materials production, especially in Denmark and Germany. The study further revealed the major differences in GWF performance among the member states due to the relative differences of waste composition, type of waste management technologies available nationally and their average level of performances despite strong regulation of waste management at European level.

Zhao et al. (2009) conducted a Life Cycle Assessment of municipal solid waste (MSW) management in Tianjin, China considering seven scenarios; 1) $48.9 \%$ MSW -to-energy plant, 
49.5\% MSW landfilling without landfill gas (LFG) utilization and the rest MSW open dumping, 2) landfilling with LFG utilization, 3) incineration (MSW-to-energy plant), 4) materials recycling, 5) centralized composting, 6) anaerobic digestion with electricity generation and 7) integration of source separation, recycling, anaerobic digestion, incineration (MSW-to-energy plant), and landfilling with LFG utilization. The seventh scenario i.e. the integrated approach revealed to be dominant in reducing GHG emissions.

Khoo et al. (2010) investigated the environmental performance of four food waste conversion scenarios - based on a life cycle assessment perspective - taking into account air emissions, useful energy from the incinerators and anaerobic digestion $(\mathrm{AD})$ process, as well as carbon dioxide mitigation from the compost products derived from the digested material and a proposed aerobic composting system. The life cycle impact results were generated for global warming, acidification, eutrophication, photochemical oxidation and energy use. The total normalized results revealed the small scale proposed aerobic composting to be more environmentally favourable than incinerators, but less ideal compared to the $\mathrm{AD}$ process.

\subsubsection{Integrated Waste Management}

Mohareb et al. (2004) carried out a study on the strategies for the municipal solid waste sector in Canada to reduce GHG emissions to meet its commitments under the Kyoto Protocol and suggested an integrated approach considering the techniques such as, source reduction, recycling, landfilling with gas collection for energy recovery, anaerobic digestion with gas collection for energy recovery, composting and incineration with electricity generation where applicable to be the effective one to reduce emissions from the solid waste sector.

Tinmaz et al. (2006) conducted a study on the current solid waste management practices and the prevailing principles in Corlu Town, Turkey with a view to improve the situation, where per capita waste generation was $1.15 \mathrm{~kg}$ per day and the composition of municipal solid waste included approximately $50 \%$ organic material and $30 \%$ recyclable materials. The study group evaluated different methods of solid waste management taking in to account of the environmental, economic and feasibility aspects and recommended an integrated approach 
consisting of separation at source, sorting, recycling, composting and sanitary landfilling with a potential reduction of landfill volume up to $27 \%$.

Mohareb et al. (2008) conducted a modelling exercise to determine GHG emissions from the waste sector in Ottawa, Ontario, Canada and suggested some options such as, waste incineration, further source separation of recyclables, and anaerobic digestion of organic wastes to have the greatest effect on reducing GHG emissions.

Asase et al. (2009) carried out a study reviewing the integrated waste management system operating in the city of London, Ontario, Canada and the possibility of utilizing lessons drawn from the system's development and operation to help implement a sustainable waste management system in the city of Kumasi, Ghana. The study identified a perfect waste management system design in place in the city of London for handling the generated waste and its appropriate disposal along with a clearly defined sector responsibilities and monitoring option. The study group attributed to the continuous improvement strategy framework adopted by the city of London based on the principles of integrated waste management for attaining the sustainability in the city and suggested a similar approach for adopting a strategic framework based on the principles of integrated waste management with a strong political and social commitment for transforming the current waste management in Kumasi and other cities in developing countries in the bid for finding lasting solutions to the problems of waste management. 


\section{CHAPTER 3}

\section{METHODOLOGY}

\subsection{Study Area and Duration}

Greater Toronto Area was identified as the study area. Greater Toronto Area comprises of 4 Regional Municipalities and the City of Toronto. Regional Municipalities are Durham, Halton, Peel and York. Study period was selected as seven years from the year 2002 to 2008 .

\subsection{Selection of Indicators}

Following indicators were selected for analysis:

i) Total quantity of waste disposed of in a year

ii) Total quantity of waste diverted in a year

iii) Percentage of waste diverted in a year

iv) Percentage composition of diverted waste

v) Total quantity of waste managed in a year

vi) Per capita waste generated in a year 


\subsubsection{Total quantity of waste disposed of in a year}

Total quantity of waste disposed of in a year is an important indicator for waste management measures. Different methods of disposal may be the options.

Total quantity of waste disposed of in a year= (Quantity of waste landfilled+Quantity of waste exported+ Quantity of waste incinerated)

\subsubsection{Total quantity of waste diverted in a year}

Total quantity of waste diverted in a year is another important indicator for waste management measures. Several options such as blue box recycling, material reuse, green bin SSo etc. may be available for achieving the highest quantity diversion from the landfills.

Total quantity of waste diverted in a year $=\sum$ (Different diversion options)

\subsubsection{Percentage of waste diverted in a year}

Percentage of waste diverted in a year is a very important indicator for waste management measures. Usually waste management target is set by fixing a certain percentage diversion for a certain year or by fixing a series of percentage diversions for a series of consecutive years. 


\subsubsection{Percentage composition of diverted waste}

Percentage composition of diverted waste is another very important indicator for waste management measures. It is a vivid picture of different diversion options with respect to total quantity of waste diverted in a year.

Percentage composition of diverted waste $=$ (Quantity diverted by a certain option/ Total quantity of waste diverted in a year)*100

\subsubsection{Total quantity of waste managed in a year}

Total quantity of waste managed in a year is another very important indicator for waste management measures.

Total quantity of waste managed in a year= Total quantity of waste disposed of in a year + Total quantity of waste diverted in a year

\subsubsection{Per capita waste generated in a year}

Per capita waste generated in a year is another very important indicator for waste management measures. Per capita waste generation is widely used as a measure of progress in waste management.

Per capita waste generated in a year= Total quantity of waste generated in a year/Total population of that year 


\subsection{Data Collection}

Data concerning residential waste collection, disposal and diversion were collected from the Regional Municipalities of Durham, Halton, Peel, York and the City of Toronto contacting them through e-mails and telephones. Some data were collected navigating through concerned websites of Regional Municipality offices and the City of Toronto. Related some other websites were also navigated which are listed in the Reference. Data from the Regional Municipalities of Durham, Halton, Peel, York and the City of Toronto are listed in Appendix-A, B, C, D and E respectively.

\subsection{Data Analysis}

Statistical analyses of collected data were carried out using the selected parameters for the study area and for the selected duration. Analysis and results are presented in details in the next chapter. 


\section{CHAPTER 4}

\section{ANALYSIS AND RESULTS}

\subsection{General}

Analyses and results are presented in this chapter in six sections, one section for each Regional Municipality, and one section for the City of Toronto and the other one for the Greater Toronto Area. Each of the first five sections contains 2002 data analysis at greater length in the first subsection and then the temporal trend from 2002-2008 in respect of waste disposal, waste diversion, diverted waste composition, population and waste generation and waste generations per capita in the next subsection. The sixth section contains comparative performances during 2002-2008 among the Regional Municipalities, the City of Toronto and the Greater Toronto Area as a whole in respect of waste disposal, waste diversion in tonnes, waste diversion in percentage, total waste managed, population growth, waste generations per capita and main findings. Cost analysis of waste management for the year 2007 is also included in the last subsection of this section. Analyzed data and results are presented in tabular forms as well as in graphical forms. Main data sources are Region of Durham (2003-2009), Region of Halton (2003-2009), Region of Peel (2003-2009), Region of York (2009), City of Toronto (2009) and Gartner Lee Limited (2008).

\subsection{Regional Municipality of Durham}

\subsubsection{Waste Management in the Year 2002}




\subsubsection{Disposal of Residential Garbage}

131,516 tonnes of curbside and multi residential garbage waste as well as unwanted bulky goods were collected in the Area Municipalities and disposed of by the Regional Municipality of Durham. This waste was primarily received at three privately operated waste transfer stations and hauled to the various Landfill sites for disposal. Four Waste Disposal Facilities located at Oshawa, Port Perry, Blackstock and Brock Township were operated by the Region. From these facilities 14,236 tonnes of garbage was landfilled to the various Landfill sites for disposal. A total of 145,752 tonnes of garbage waste was landfilled in 2002 as shown in the Table 4.1. This was a decrease of 805 tonnes over the previous year. This waste represented $70.70 \%$ of the total waste managed.

\section{Table-4.1 Durham Region 2002 Waste landfilled}

\begin{tabular}{|c|c|c|}
\hline Description & $\begin{array}{c}\text { Garbage } \\
\text { Waste } \\
\text { (tonnes) }\end{array}$ & $\begin{array}{c}\text { Landfilled } \\
\text { (tonnes) }\end{array}$ \\
\hline Curbside and multi-residential waste collection & 131,516 & 131,516 \\
\hline Waste collected at Regional waste disposal sites & 14,236 & 14,236 \\
\hline Total & 145,752 & 145,752 \\
\hline
\end{tabular}

Source: Regional Municipality of Durham, 2003

\subsubsection{Waste Diversion}

A total of 60,403 tonnes of material was diverted away from the landfill disposal by the Region of Durham. The diversion rate for the year 2002 was $29.30 \%$ as shown in the Table 4.2 . 


\section{A. Blue Box Recycling}

In the year 2002, 34,063 tonnes of waste material was diverted through curbside and 2,321 tonnes from apartment recycling program and 1,354 tonnes at Region's waste facilities totalling 37,738 tonnes were diverted by the Region of Durham as shown in the Table 4.2. The blue box recycling program represented $18.3 \%$ of the total waste system managed by the Region.

B. Leaf and Yard Waste Composting

In 2002,12,448 tonnes were collected from curbside and 2,200 tonnes were collected at Region's waste facilities for a total of 14,648 tonnes as shown in the Table 4.2. This waste diversion program represented $7.1 \%$ of the waste stream.

C. Material Reuse

The Region offered residents the opportunity to divert electronics, wood, brush, drywall, tires, scrap metal, appliances, batteries, oil and oil filters, blue box recyclables, propane tanks, paints and other household hazardous wastes from landfill disposal. In total, 5,757 tonnes were diverted from landfill disposal as shown in the Table 4.2 through various re-use and exchange programs. This waste diversion program represented $2.8 \%$ of the waste stream. 


\section{Grasscycling and Composting (credits)}

Grasscycling is simply leaving the grass clippings on the lawn. Waste diversion credits are earned as a result of municipal bans on collecting grass clippings and the use of backyard composters by the residents. These two residential composting programs resulted in 2,260 tonnes of organic waste as shown in the Table 4.2 being diverted from collection and landfill disposal. This waste diversion program represented $1.1 \%$ of the waste stream.

\section{Table-4.2 2002 Residential Waste Diversion}

\begin{tabular}{|l|c|c|}
\hline \multicolumn{1}{|c|}{ Type/Program } & Tonnes & \% of Total Waste Managed \\
\hline Curbside \& Apartment Recycling & 37,738 & 18.3 \\
\hline Leaf \& Yard Waste Composting & 14,648 & 7.1 \\
\hline Reuse Programs & 5,757 & 2.8 \\
\hline Grass Cycling \& Composting credit & 2,260 & 1.1 \\
\hline Total & 60,403 & 29.3 \\
\hline
\end{tabular}

Source: Regional Municipality of Durham, 2003

E. Diverted Waste Composition

The diverted wastes constituted $62 \%$ curbside and apartment recycling materials, $24 \%$ leaf and yard waste composting materials, $10 \%$ re-used materials and $4 \%$ grasscycling and composting material as shown in the Figure 4.1. 


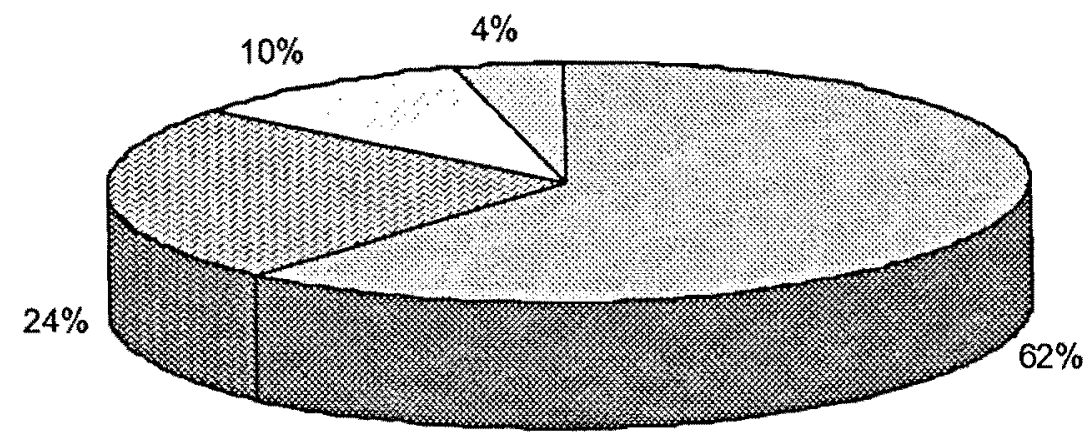

- Curbside \& Apartment Recycling $\quad$ Leaf \& Yard Waste Composting

$\square$ Reuse Programs $\square$ Grasscycling \& Composting credit

Figure 4.1 Composition of Diverted Waste in 2002

\subsubsection{Population and Quantity of Waste Managed}

In the year 2002, the population of Durham Region was 536,575 , the total quantity of waste managed through different diversion programs and landfilling was 206,155 tonnes and the diversion rate was $29.30 \%$ as shown in the Table 4.3 .

Table-4. 3 Durham Region 2002 Waste Management

\begin{tabular}{|c|c|c|c|c|}
\hline & $\begin{array}{c}\text { Quantity } \\
\text { Managed } \\
\text { (tonnes) }\end{array}$ & $\begin{array}{c}\text { Quantity } \\
\text { Diverted } \\
\text { (tonnes) }\end{array}$ & Diversion Rate & $\begin{array}{c}\text { Waste } \\
\text { Landfilled } \\
\text { (tonnes) }\end{array}$ \\
\hline 536,575 & 206,155 & 60,403 & $29.30 \%$ & 145,752 \\
\hline
\end{tabular}

Source: Regional Municipality of Durham, 2003 


\subsubsection{Temporal Trend from $2002-2008$}

\subsubsection{Waste Disposal}

In the Region of Durham, waste disposal was composed of curbside \& multi-residential waste collection and regional waste disposal site collection. A total of 145,752 tonnes of waste was disposed of in 2002 with a decrease in disposal to 144,937 tonnes in 2003 and a rise to 149,424 tonnes in 2004. Waste disposal decreased gradually from 2004 through the years 2005, and 2006 to 116,286 tonnes in 2007 and 116,464 tonnes in 2008. Waste disposal trend is shown in Figure 4.2. Curbside \& multi-residential waste collection increased by $38 \%$ from 2002 to 2008 and regional waste disposal site collection decreased by $26 \%$ during the same period. But the historical trend of total waste disposal shows a reduction in total quantity by $20 \%$ from 2002 to 2008 and a reduction of total quantity by $22 \%$ in 2008 from the highest quantity in 2004 . This happened due to significant increase of diversion rate in the same year.

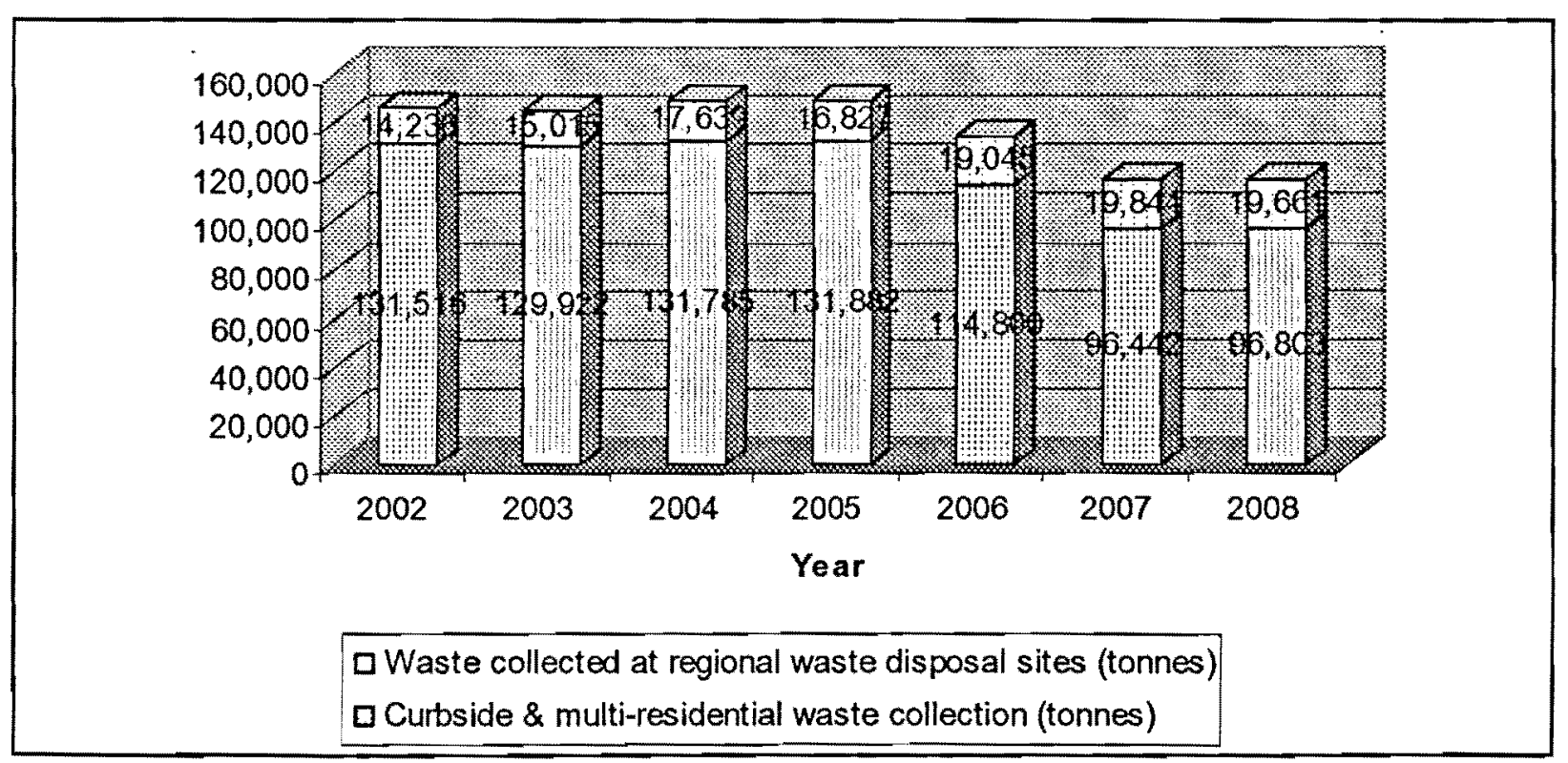

Figure 4.2 Waste Disposal of Durham Region 


\subsubsection{Waste Diversion}

The Region of Durham achieved a gradual increase in diversion rate from $29 \%$ in 2002 through the years $2003,2004,2005,2006$, and 2007 to $51 \%$ in 2008 . Quantitative diversions through the years $2002,2003,2004,2005,2006,2007$ and 2008 were 60,403 tonnes, 64,920 tonnes, 72,394 tonnes, 83,317 tonnes, 105,868 tonnes, 116,671 tonnes and 119,126 tonnes respectively. The diversion trend is shown in Figure 4.3. Historical trend shows a positive diversion trend from 2002 to 2008. The region successfully met the goal of achieving 50\% diversion rate in 2007 as was set in the 1999 Regional Council approved Long Term Waste Management Strategy Plan. It is evident from the figure that the introduction of food composting in 2003 played a significant role in increasing diversion rates in the years 2006, 2007 and 2008. Above all, the continued promotion of Region's waste management programs including different promotion and education activities such as media presentations, public presentations, printed materials and other community activities resulted in $51 \%$ diversion rate in 2008 .

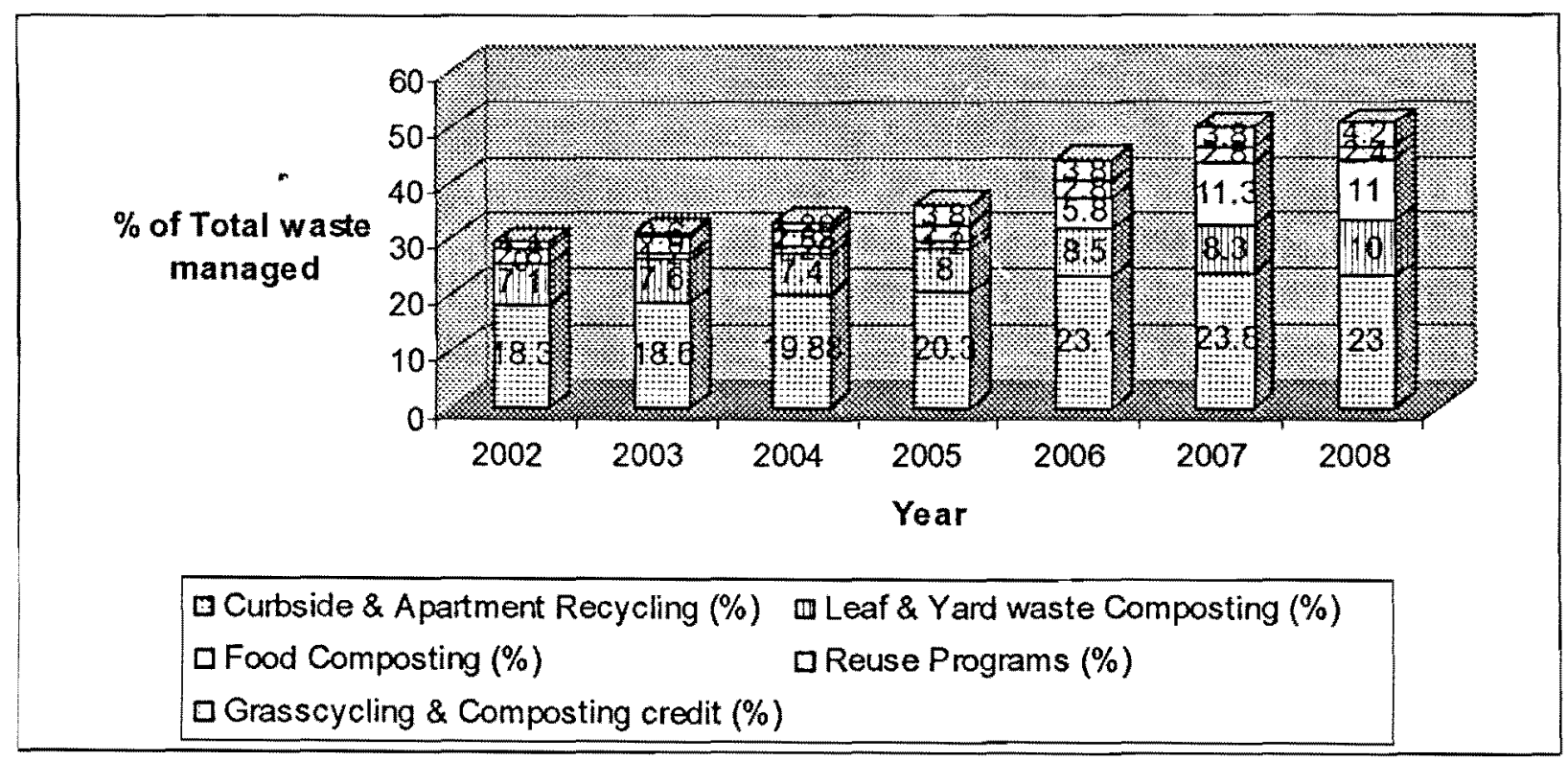

Figure 4.3 Waste Diversion of Durham Region 


\subsubsection{Diverted Waste Composition}

Changes in diverted waste compositions from 2003 to 2008 are shown in Figures 4.4 to 4.9. Since inception of the program i.e. from 2003 , food composting increased from $4 \%$ to $13 \%$ in 2006 and $22 \%$ in 2007 and 2008 . Grass cycling \& composting credit also increased from $2 \%$ in 2003 to $8 \%$ in 2008. Curbside recycling gradually decreased from $60 \%$ in 2003 to $45 \%$ in 2008 which was $62 \%$ in 2002 . Reuse program decreased from $9 \%$ in 2003 to $5 \%$ in 2008 which was $10 \%$ in 2002 . Leaf \& yard waste composting decreased from $25 \%$ in 2003 to $20 \%$ in 2008 which was $24 \%$ in 2002 .

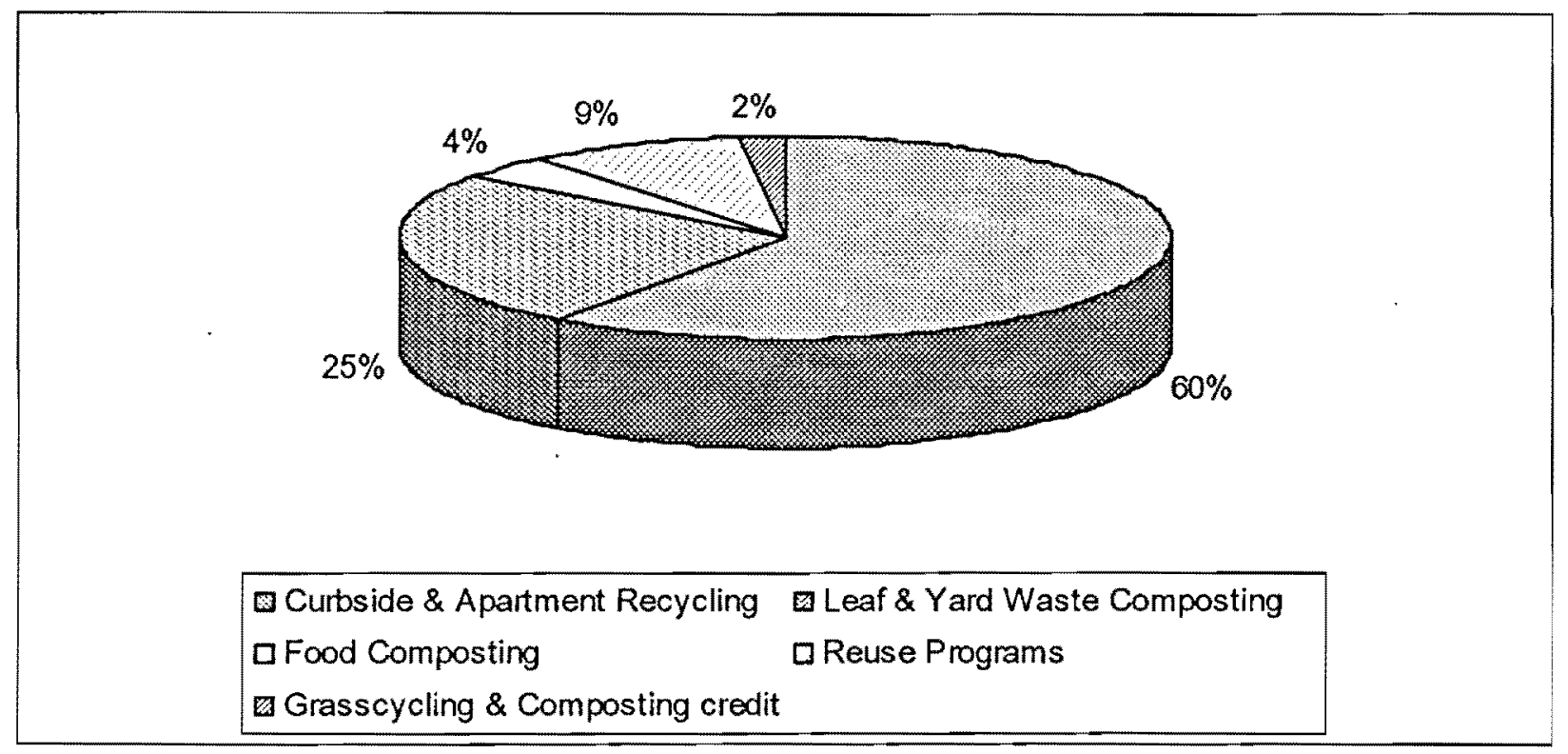

Figure 4.4 Composition of Diverted Waste in 2003 


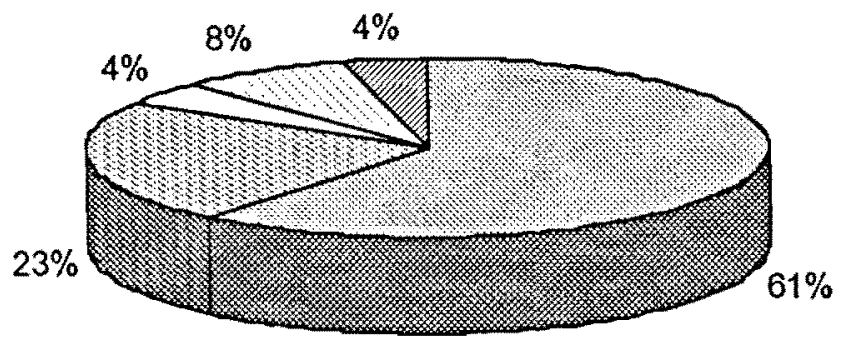

.⿴囗大 Curbside \& Apartment Recycling

- Leaf \& Yard Waste Composting

口Food Composting

D Reuse Programs

Grasscycling \& Composting credit

Figure 4.5 Composition of Diverted Waste in 2004

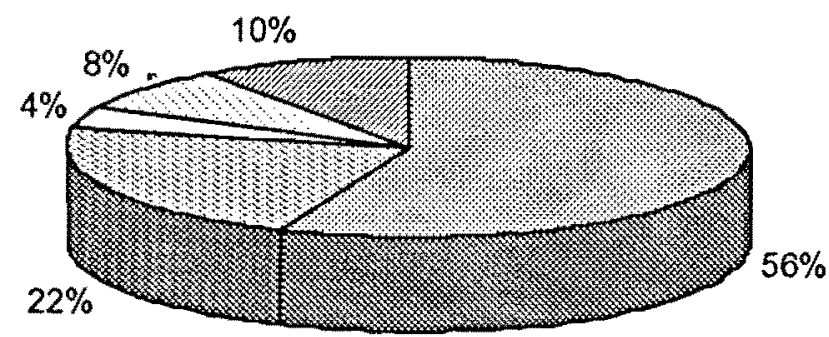

. Curbside \& Apartment Recycling

Leaf \& Yard Waste Composting

a Food Composting

$\square$ Reuse Programs

ש Grasscycling \& Composting credit

Figure 4.6 Composition of Diverted Waste in 2005 


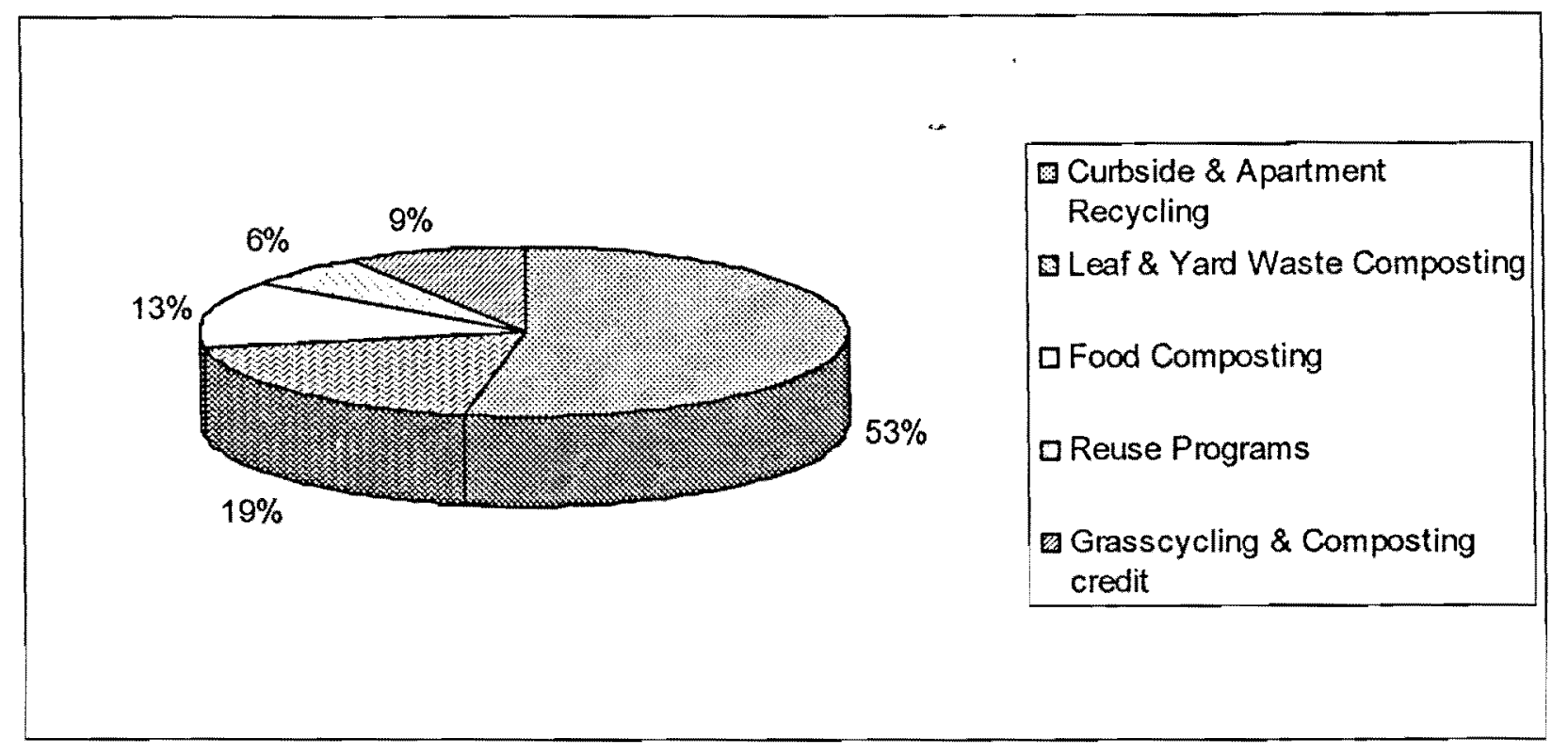

Figure 4.7 Composition of Diverted Waste in 2006

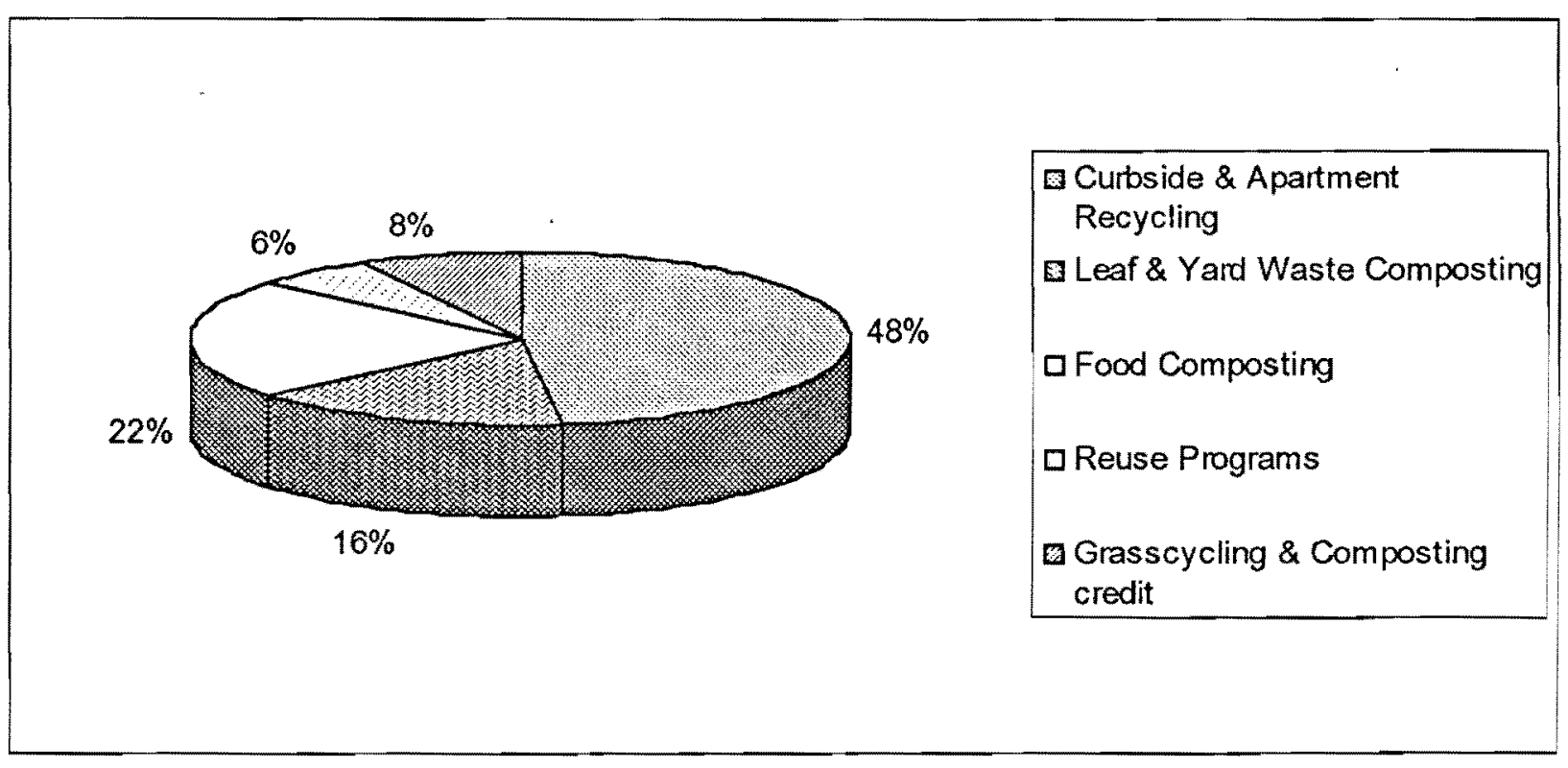

Figure 4.8 Composition of Diverted Waste in 2007 


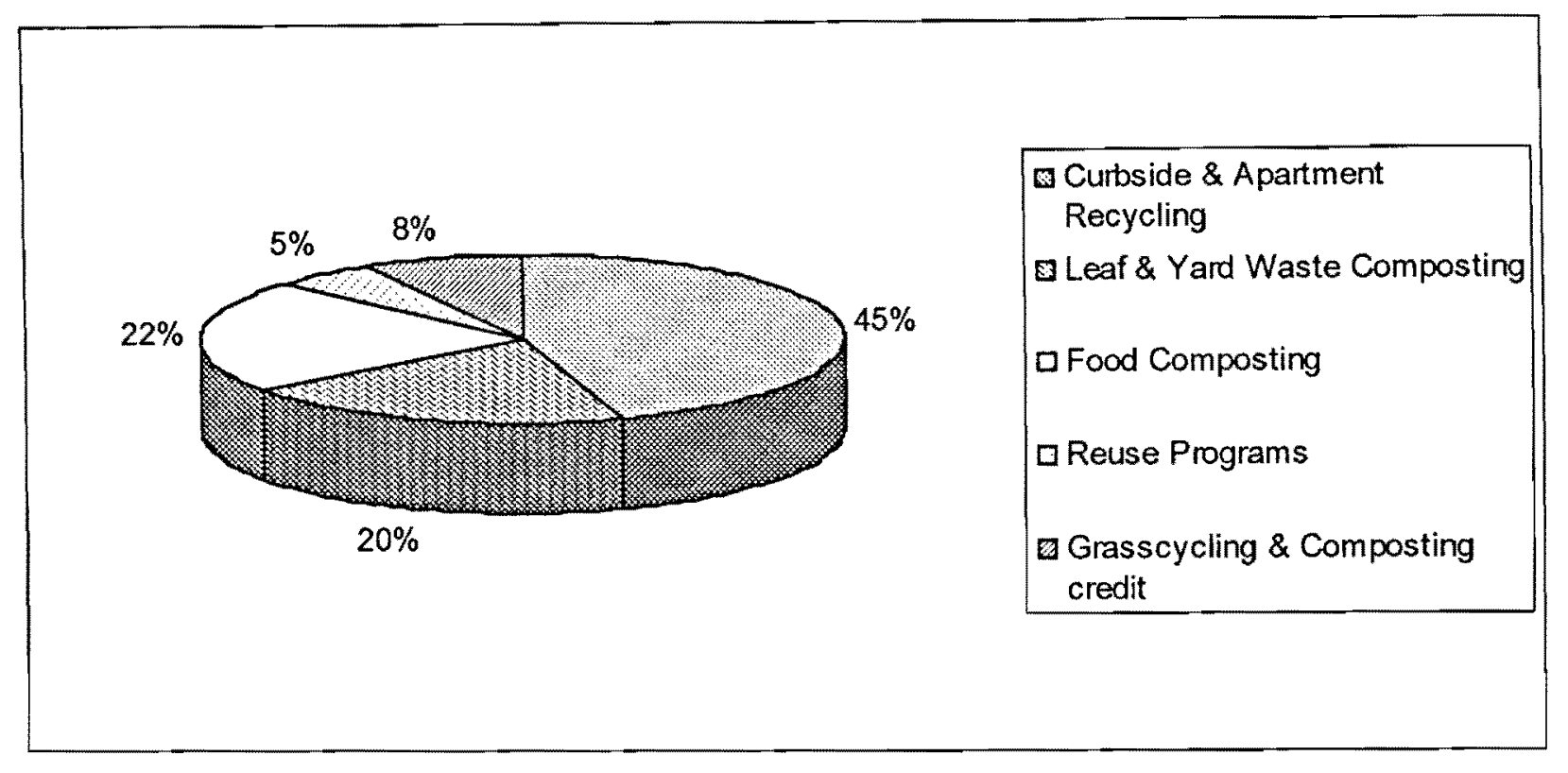

Figure 4.9 Composition of Diverted Waste in 2008

\subsubsection{Population and Waste Generation}

Population of Durbam Region was 536,575 in 2002 and increased gradually through 2003, 2004, 2005,2006 and 2007 to 605,730 in 2008. Waste generation also grew from 206,155 tonnes in 2002 through 2003, 2004, and 2005 to 239,713 tonnes in 2006 with a decrease to 232,957 tonnes in 2007 and a rise again to 235,590 tonnes in 2008 . The trends of population growth and waste generation are shown in Figure 4.10. 


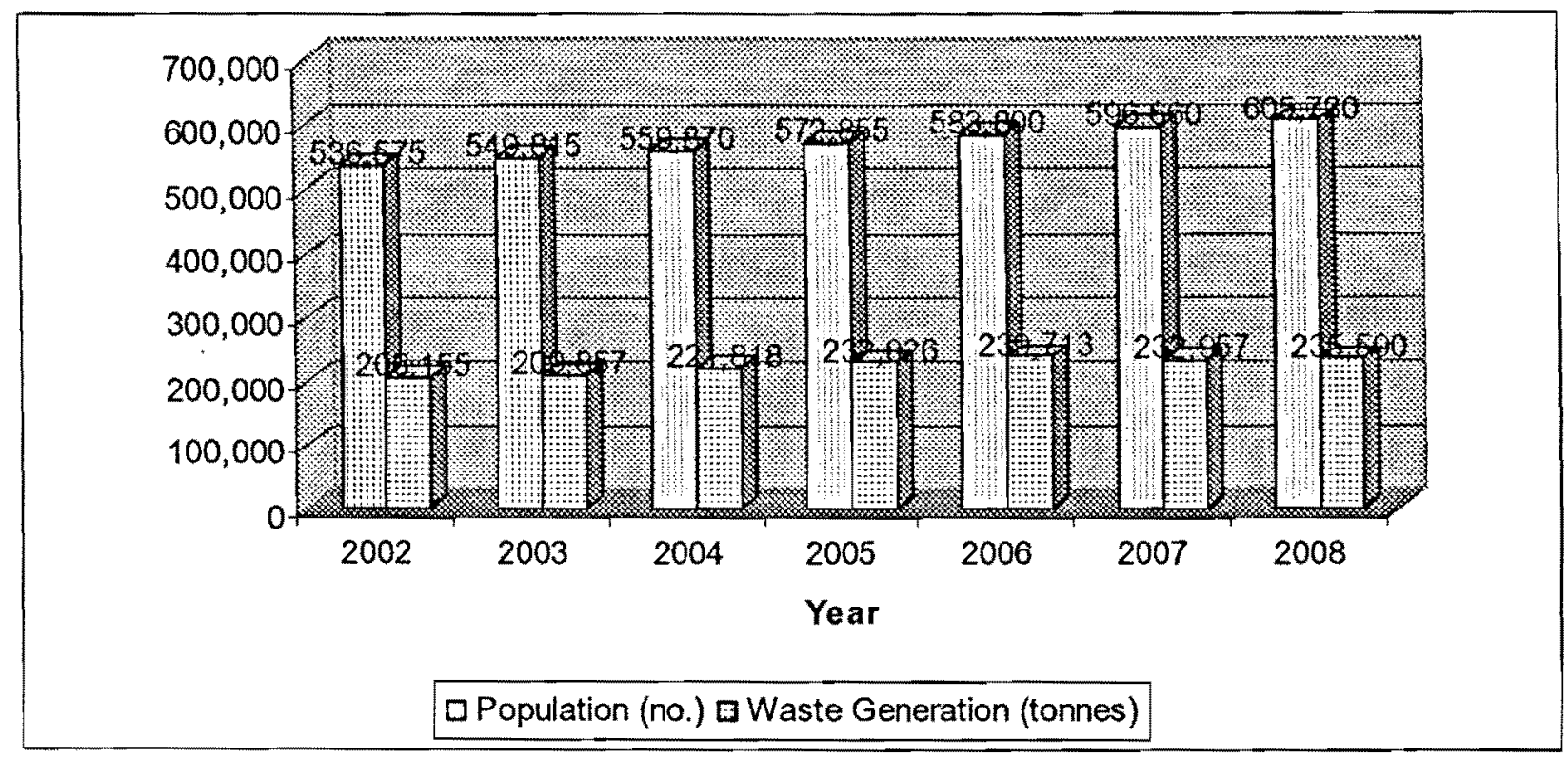

Figure 4.10 Population Growths and Waste Generation

\subsubsection{Waste Generations Per Capita}

In the Region of Durham waste generation per capita was $384 \mathrm{Kg}$ in 2002 with a decrease to 382 $\mathrm{Kg}$ in 2003 and increased through the years 2003,2004 and 2005 to $411 \mathrm{Kg}$ in 2006 . Waste generation per capita decreased to $390 \mathrm{Kg}$ in 2007 and $389 \mathrm{Kg}$ in 2008 . The trend of waste generation per capita is shown in Figure 4.11. The historical trend of per capita waste generation shows a significant reduction of $389 \mathrm{Kg}$ in 2008 from the highest value of $411 \mathrm{Kg}$ in 2006 during 2002-2008. 


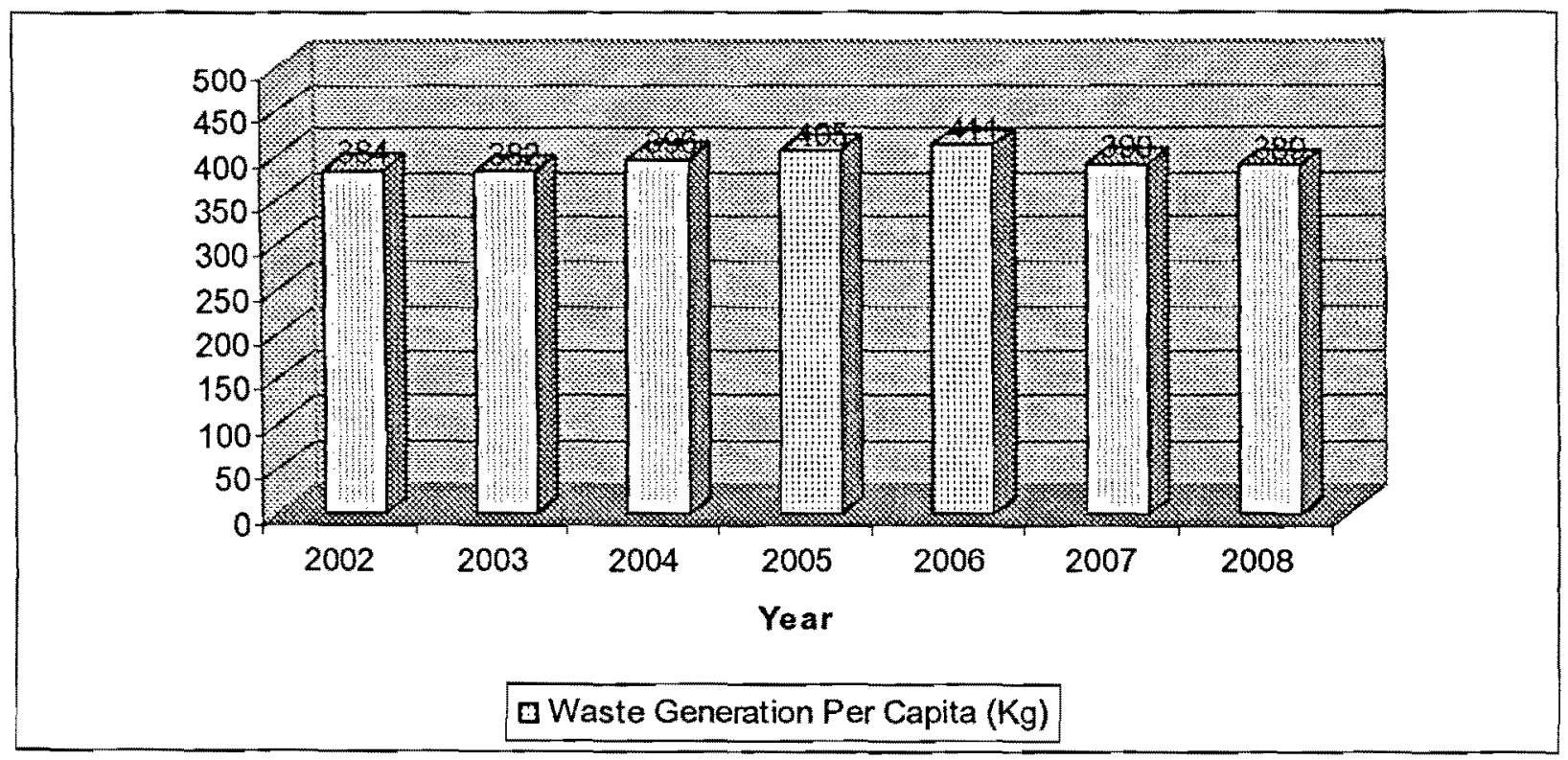

Figure 4.11 Waste Generations Per Capita

\subsection{Regional Municipality of Halton}

\subsubsection{Waste Management in the Year 2002}

\subsubsection{Disposal of Garbage}

85,984 tonnes of residential waste, 4,922 tonnes of multi-unit front end waste, 9,656 tonnes of container station: waste and 1,368 tonnes of Halton recycling residential waste were collected by the Regional Municipality of Halton. A total of 101,930 tonnes of garbage waste was landfilled by the Region in 2002 as shown in the Table 4.4 . This waste represented $60.4 \%$ of the total waste managed. 


\section{Table 4.4 Halton Region 2002 Waste Landfilled}

\begin{tabular}{|l|c|c|}
\hline Description & $\begin{array}{c}\text { Garbage Waste } \\
\text { (tonnes) }\end{array}$ & $\begin{array}{c}\text { Landfilled } \\
\text { (tonnes) }\end{array}$ \\
\hline Residential Waste & 85,984 & 85,984 \\
\hline Multi-Unit Front End Waste & 4,922 & 4,922 \\
\hline Container station: Waste & 9,656 & 9,656 \\
\hline Halton Recycling Residential Waste & 1,368 & 1,368 \\
\hline Total & 101,930 & 101,930 \\
\hline
\end{tabular}

Source: Regional Municipality of Halton, 2003

\subsubsection{Waste Diversion}

A total of 66,912 tonnes of material was diverted away from the landfill disposal by the Region of Halton. The diversion rate for the year 2002 was $39.6 \%$ as shown in the Table 4.5 .

A. Curbside Blue Box \& Multi-Unit Blue Bin Recycling and Igloo Depots

In the year 2002,27,584 tonnes of waste material was diverted through curbside blue box, 3,353 tonnes from multi-unit blue bin program and 1,417 tonnes from igloo depots totalling 32,354 tonnes were diverted by the Region of Halton as shown in the Table 4.5. The blue box and blue bin recycling program represented $19.1 \%$ of the total waste system managed by the Region. 
B. Material Reuse

The Region offered residents the opportunity to divert electronics, wood, paper, drywall, tires, scrap metal, mixed containers, foam, OCC, metal/white goods and household hazardous wastes from landfill disposal. In total, 4,851 tonnes were diverted from landfill disposal as shown in the Table 4.5 through various re-use and exchange programs. This waste diversion program represented $2.9 \%$ of the waste stream.

C. Leaf, Yard Waste \& Brush

In 2002, 8,110 tonnes of leaves, 915 tonnes of yard waste from container station, 8,937 tonnes yard waste from curbside and 877 tonnes of brush were collected at Region's waste facilities for a total of 18,839 tonnes as shown in the Table 4.5 . This waste diversion program represented $11.2 \%$ of the waste stream.

D. Grasscycling and Backyard Composting

In 2002, 4,272 tonnes waste were diverted through grasscycling and 6,294 tonnes were diverted through backyard composting. These two residential composting programs resulted in 10,566 tonnes of organic waste as shown in the Table 4.5 being diverted from collection and landfill disposal. This waste diversion program represented $6.3 \%$ of the waste stream. 
E. Christmas Trees

In 2002, 302 tonnes of Christmas trees were diverted from landfill by the Region of Halton as shown in the Table 4.5. This waste diversion program represented $0.1 \%$ of the waste stream.

\section{Table 4.5 Halton Region 2002 Waste Diversion}

\begin{tabular}{|l|c|c|}
\hline Program & Tonnes & \% of Total Waste Managed \\
\hline $\begin{array}{l}\text { Curbside \& Multi-Unit Blu Box and } \\
\text { Igloo Depot }\end{array}$ & 32,354 & 19.1 \\
\hline Material Reuse & 4,851 & 2.9 \\
\hline Leaf, Yard Waste \& Brush & 18,839 & 11.2 \\
\hline Grasscycling \& Backyard Composting & 10,566 & 6.3 \\
\hline Chrismas Trees & 302 & 0.1 \\
\hline Total & 66,912 & 39.6 \\
\hline
\end{tabular}

Source: Regional Municipality of Halton, 2003

F. Diverted Waste Composition

The diverted wastes constituted $48 \%$ curbside \& multi-unit blue box and igloo depots materials, $28 \%$ leaf, yard waste $\&$ brush, $7 \%$ re-used materials and $16 \%$ grasscycling and composting materials as shown in the Figure 4.12. 


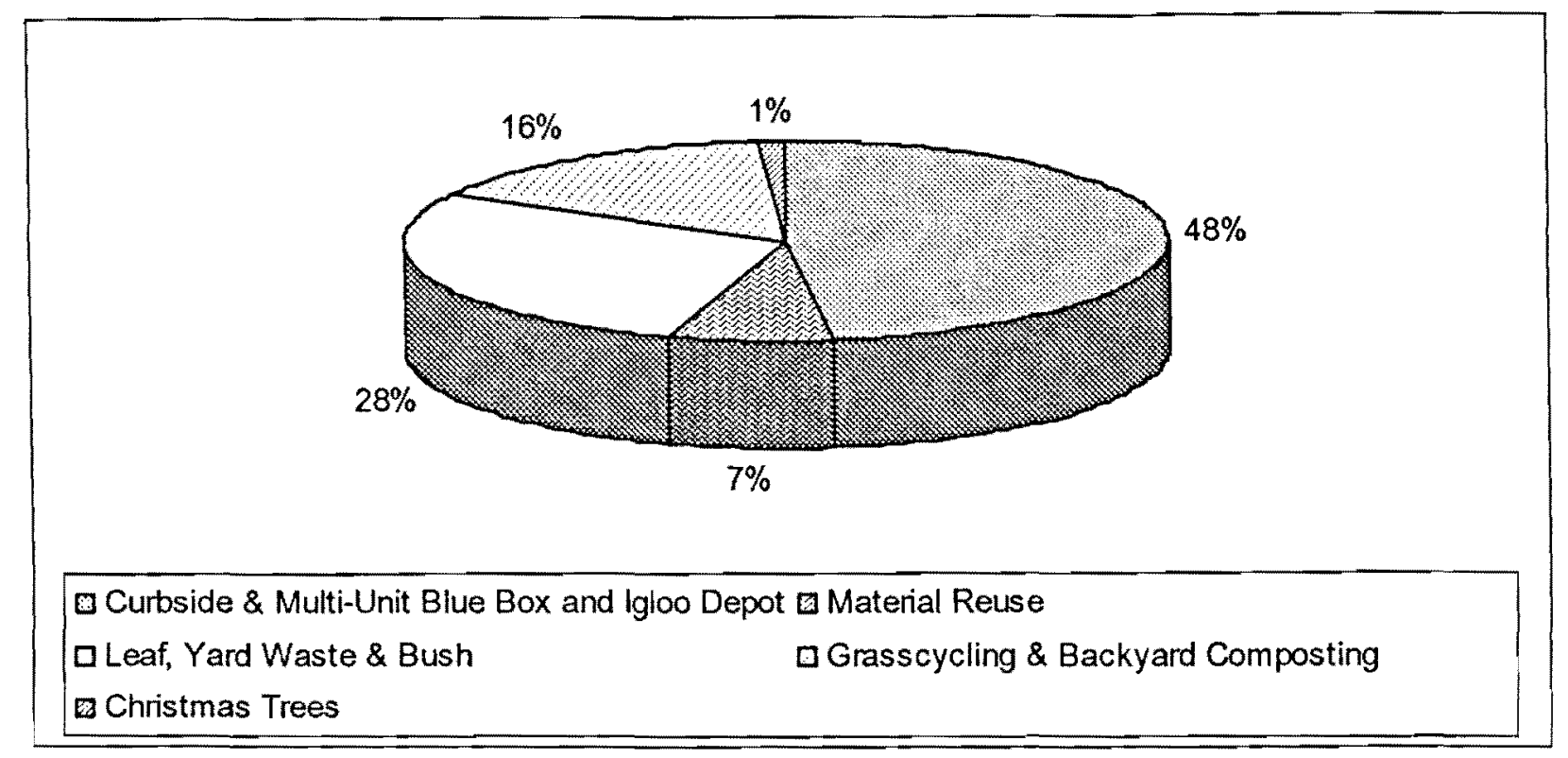

Figure 4.12 Composition of Diverted Waste in 2002

\subsubsection{Population and Quantity of Waste Managed}

In the year 2002, the population of Halton Region was 389,000 , the total quantity of waste managed through different diversion programs and landfilling was 168,842 tonnes and the diversion rate was $39.6 \%$ as shown in the Table 4.6 .

Table 4.6 Halton Region 2002 Waste Management

\begin{tabular}{|c|c|c|c|c|}
\hline Population & $\begin{array}{c}\text { Quantity } \\
\text { Managed } \\
\text { (tonnes) }\end{array}$ & $\begin{array}{c}\text { Quantity } \\
\text { Diverted } \\
\text { (tonnes) }\end{array}$ & Diversion Rate & $\begin{array}{c}\text { Waste } \\
\text { Landfilled } \\
\text { (tonnes) }\end{array}$ \\
\hline 386,900 & 168,842 & 66,912 & $39.6 \%$ & 101,930 \\
\hline
\end{tabular}

Source: Regional Municipality of Halton, 2003 


\subsubsection{Temporal Trend from 2002-2008}

\subsubsection{Waste Disposal}

In the Region of Halton, waste disposal was composed of residential waste, rural waste, multiunit front end waste, container station: waste, residential tipping face waste and Halton recycling residential waste. In the year 2002, Halton waste disposal was composed of residential waste, multi-unit front end waste, container station: waste and Halton recycling residential waste. Halton waste disposal included rural waste in 2004 and residential tipping face waste in 2005. In the Region of Halton, a total of 101,930 tonnes of waste was disposed of in 2002 with a gradual increase to 120,421 tonnes in 2006. Waste disposal decreased to 120,267 tonnes in 2007 and 92,775 tonnes in 2008. Waste disposal trend is shown in Figure 4.13. Container station: waste increased by $20.5 \%$ from 2002 to 2008 and residential waste decreased by about $18 \%$ during the same period. But the historical trend of total waste disposal shows a reduction in total quantity by $9 \%$ from 2002 to 2008 and a reduction of quantity by $23 \%$ in 2008 from the highest quantity in 2006. This happened due to significant increase of diversion rate in the same year.

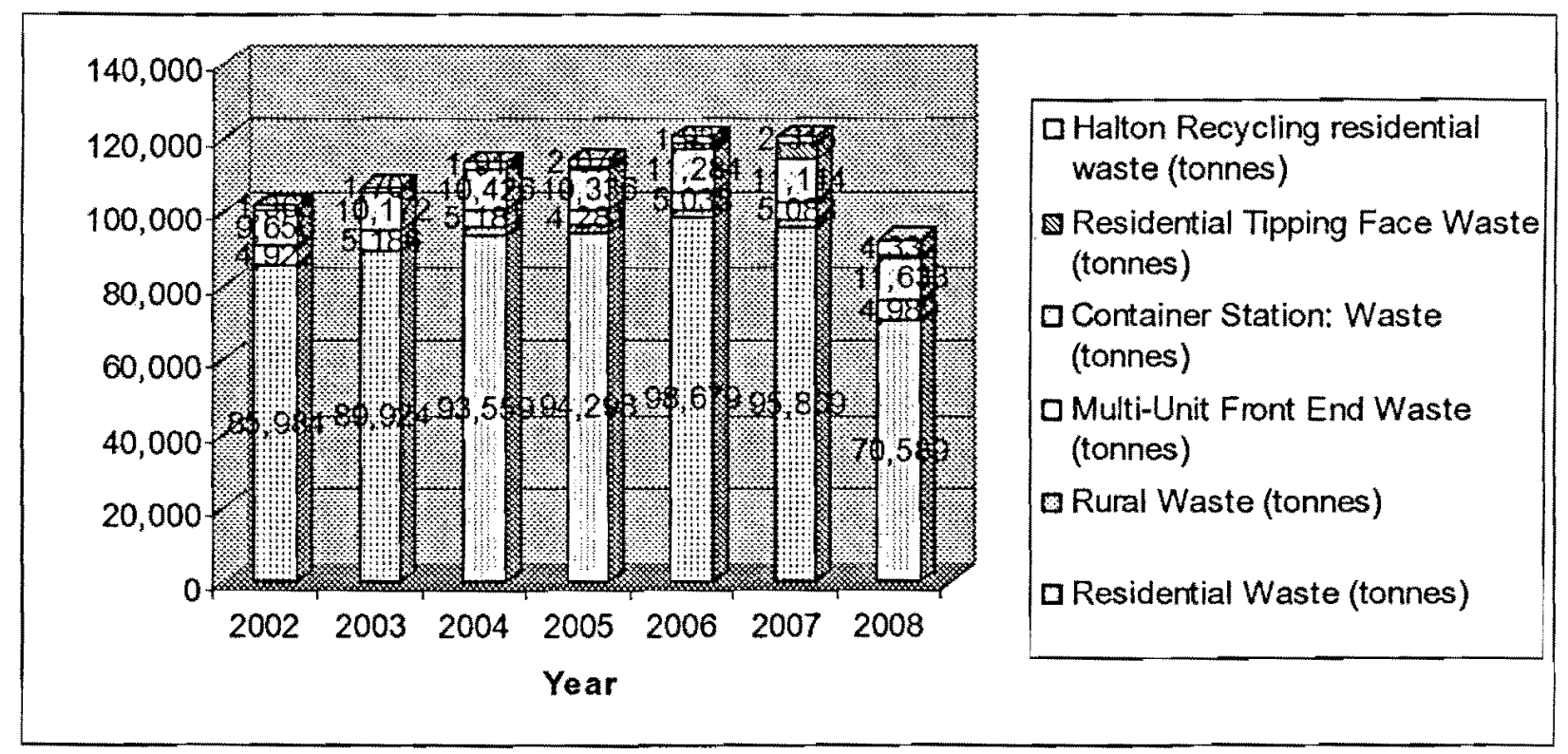

Figure 4.13 Waste Disposal of Halton Region 


\subsubsection{Waste Diversion}

The Region of Halton achieved a gradual increase in diversion rate from $39.6 \%$ in 2002 through the years 2003,2004 , and 2005 to $43.1 \%$ in 2006 with a decrease to $41.7 \%$ in 2007 and finally a rise to $56.6 \%$ in 2008. Quantitative diversions through the years 2002, 2003, 2004, 2005, 2006, 2007 and 2008 were 66,912 tonnes, 74,098 tonnes, 80,539 tonnes, 84936 tonnes, 91,396 tonnes, 85,849 tonnes and 121,201 tonnes respectively. The diversion trend is shown in Figure 4.14. Waste diversion decreased from $43.1 \%$ in 2006 to $41.7 \%$ in 2007 due to the diversion of glass from the blue box program to the LCBO bag, a back deposit return program. With the exception in 2007 , historical trend shows a positive diversion trend from 2002 to 2008 . Residential waste diversion rate of $56.6 \%$ in 2008 showed a significant increase from $39.6 \%$ diversion rate in 2002 . It is evident from the figure that the introduction of kitchen/green cart organics program in 2005 played a significant role ( $8.6 \%$ of the total waste managed) in increasing diversion rate in 2008. Above all, the achievement of $56.6 \% \%$ diversion rate in 2008 was due to the implementation of once a week residential Blue Box and Green Cart collection and once every other week collection of garbage. Diversion rate was further influenced by the enhanced communication regarding new curbside collection services, public workshops, etc. 


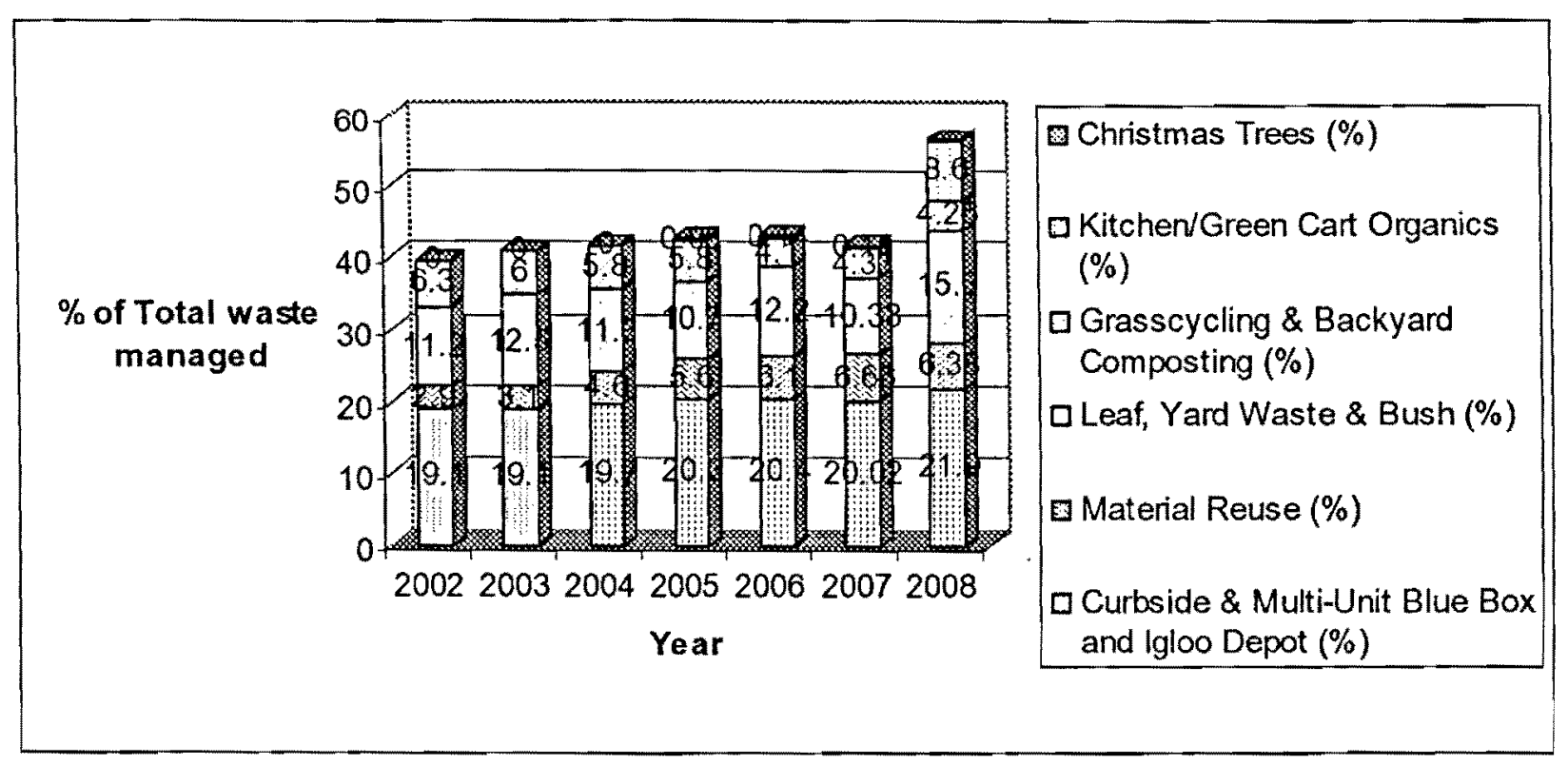

Figure 4.14 Waste Diversion of Halton Region

\subsubsection{Diverted Waste Composition}

Changes in diverted waste compositions from 2003 to 2008 are shown in Figures 4.15 to 4.20 . Kitchen/green cart organics program achieved $15 \%$ of the diverted waste in 2008 . Curbside \& multi-unit blue box and igloo depot program decreased from $47 \%$ in 2003 to $39 \%$ in 2008 which was $48 \%$ in 2002. Grasscycling \& backyard composting program decreased from $15 \%$ in 2003 to $8 \%$ in 2008 which was $16 \%$ in 2002 . Leaf, yard waste \& bush decreased from $30 \%$ in 2003 to $27 \%$ in 2008 which was $28 \%$ in 2002 . Material reuse program increased from $8 \%$ in 2003 to $11 \%$ in 2008 which was $7 \%$ in 200 


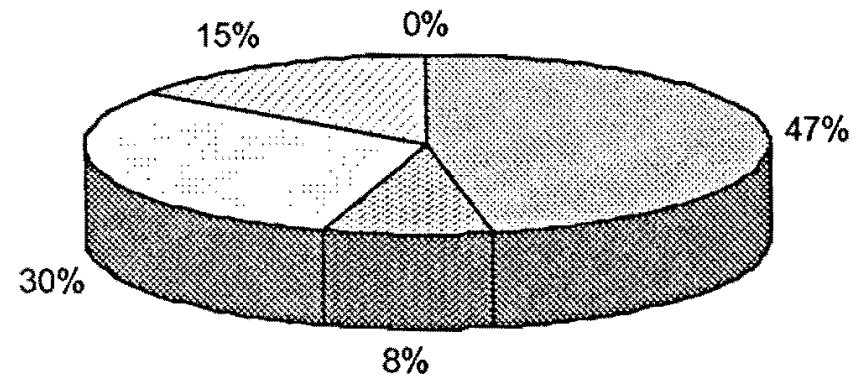

Curbside \& Multi-Unit Blue Box and Igloo Depot

G Material Reuse

口 Leaf, Yard Waste \& Bush

Grasscycling \& Backyard Composting

Christmas Trees

Figure 4.15 Composition of Diverted Waste in 2003

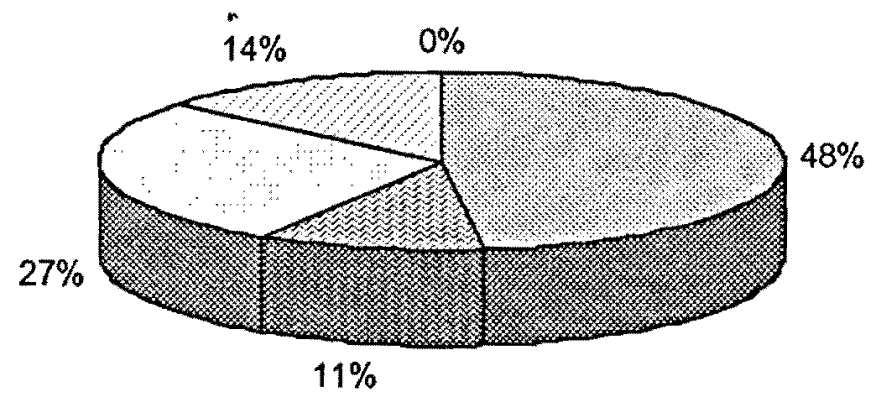

จ Curbside \& Multi-Unit Blue Box and Igloo Depot

@ Material Reuse

a Leaf, Yard Waste \& Bush

口 Grasscycling \& Backyard Composting

Christmas Trees

Figure 4.16 Composition of Diverted Waste in 2004 


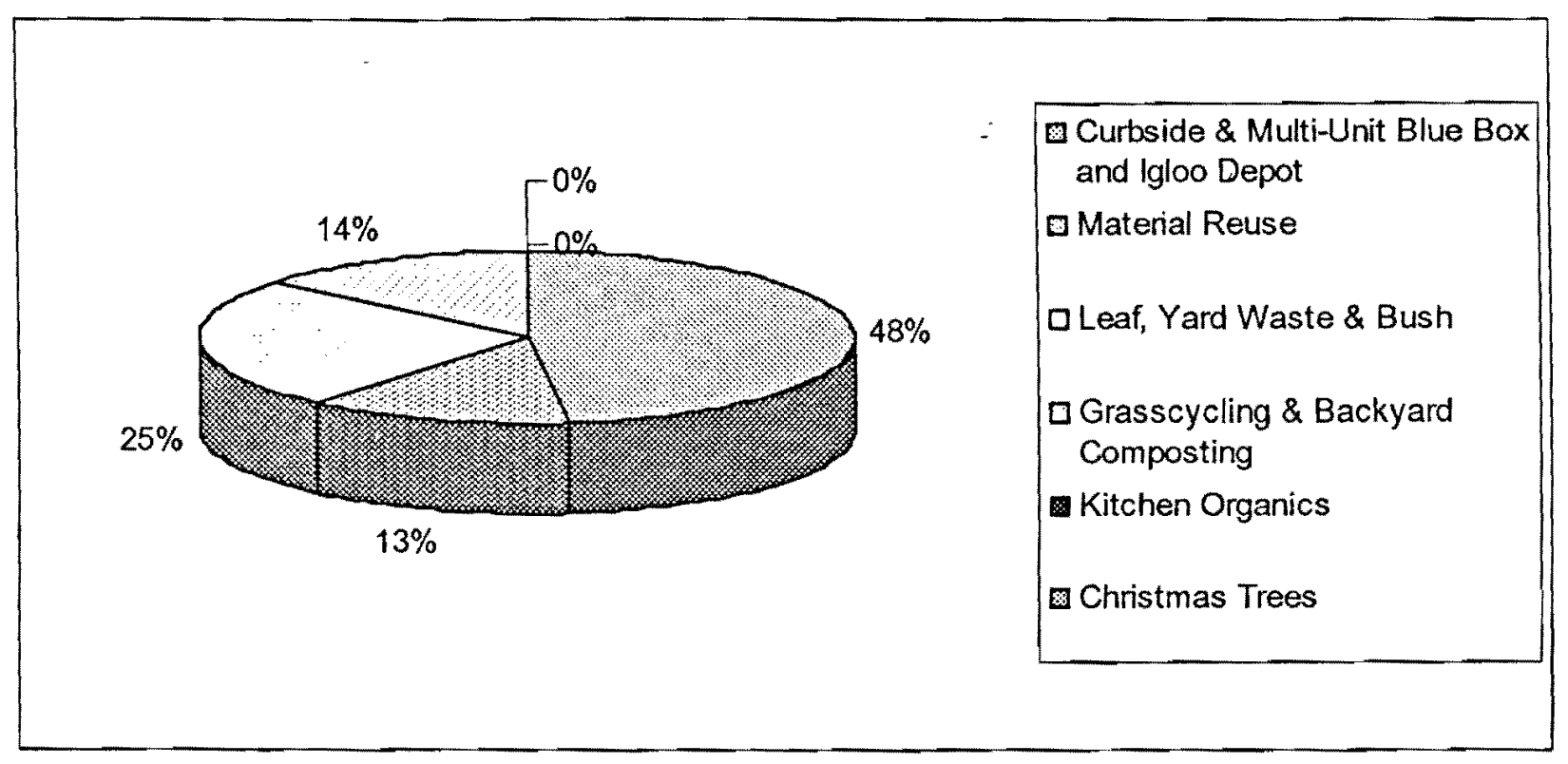

\section{Figure 4.17 Composition of Diverted Waste in 2005}

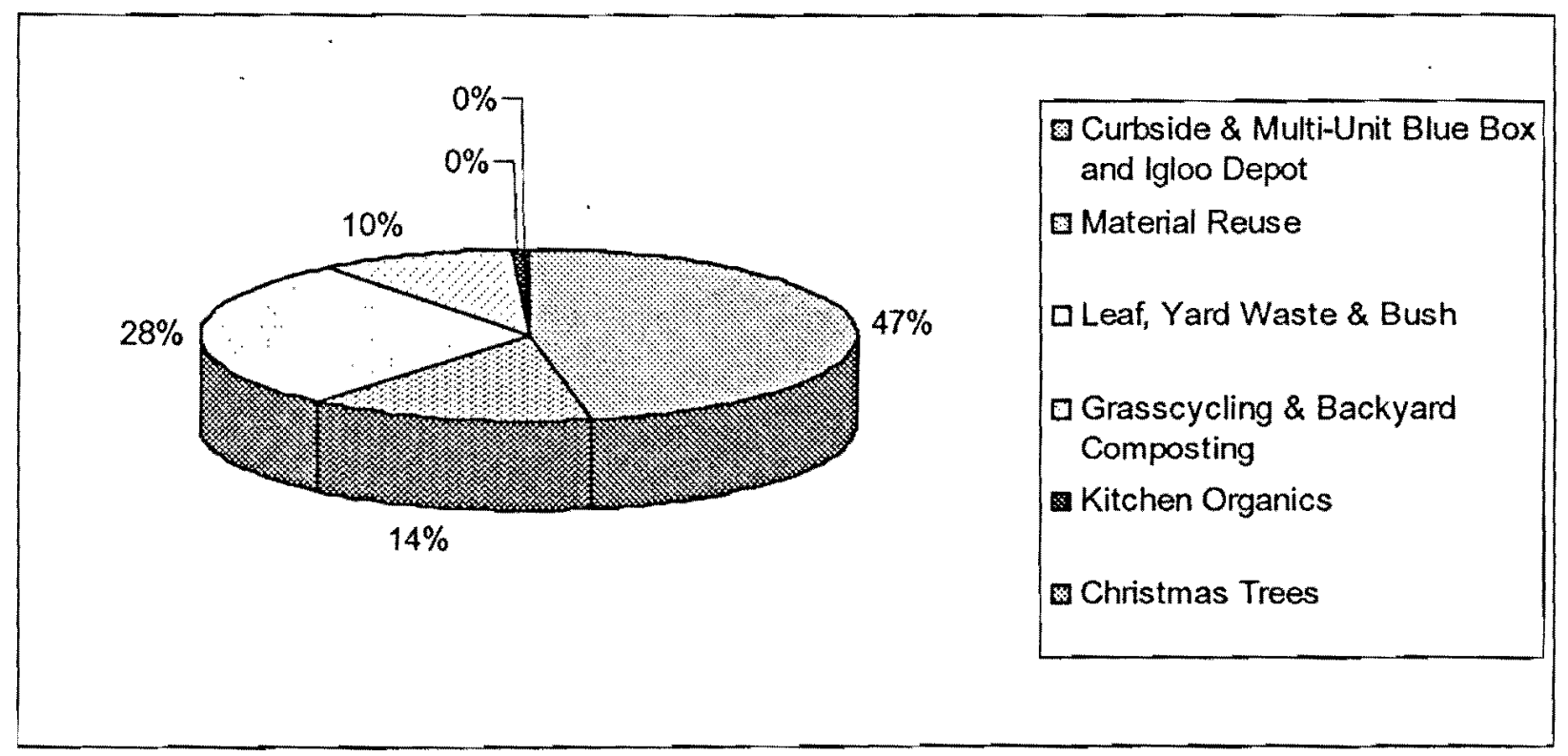

Figure 4.18 Composition of Diverted Waste in 2006 


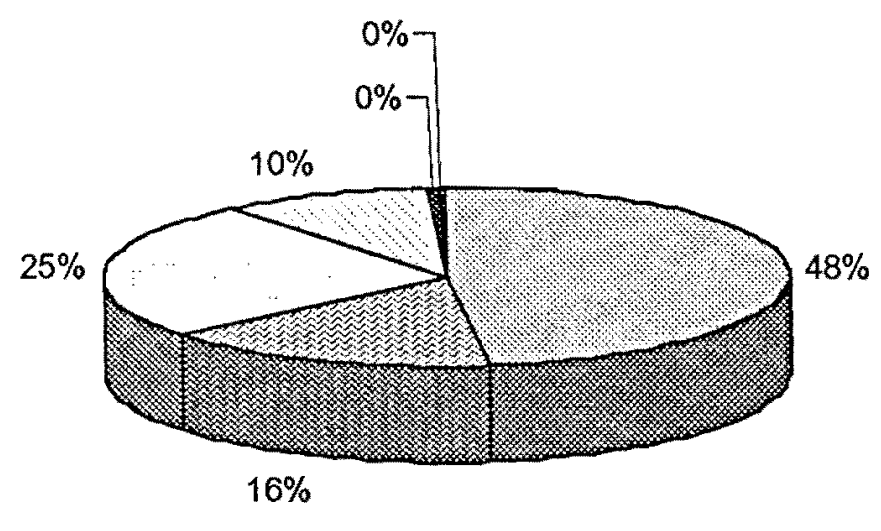

ø Curbside \& Multi-Unit Blue Box and Igloo Depot

Material Reuse

- Leaf, Yard Waste \& Bush

口 Grasscycling \& Backyard Composting

Kitchen Organics

Christmas Trees

\section{Figure 4.19 Composition of Diverted Waste in 2007}

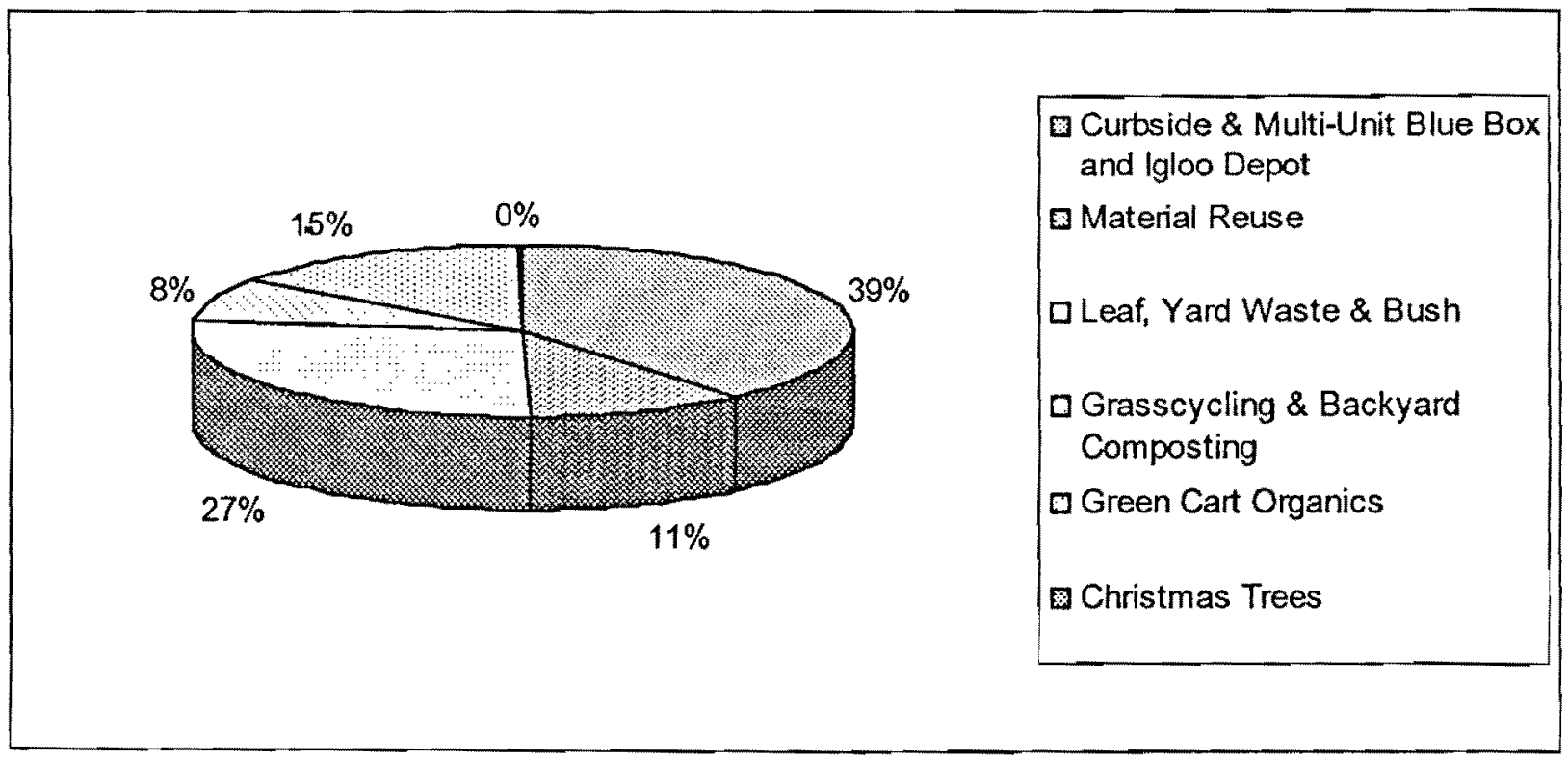

Figure 4.20 Composition of Diverted Waste in 2008 


\subsubsection{Population and Waste Generation}

Population of Halton Region was 386,900 in 2002 and increased gradually through 2003, 2004, 2005,2006 and 2007 to 466,930 in 2008 . Waste generation also grew from 168,842 tonnes in 2002 through 2003,2004 , and 2005 to 211,817 tonnes in 2006 with a decrease to 206,117 tonnes in 2007 and a rise again to 213,976 tonnes in 2008 . The trends of population growth and waste generation are shown in Figure 4.21.

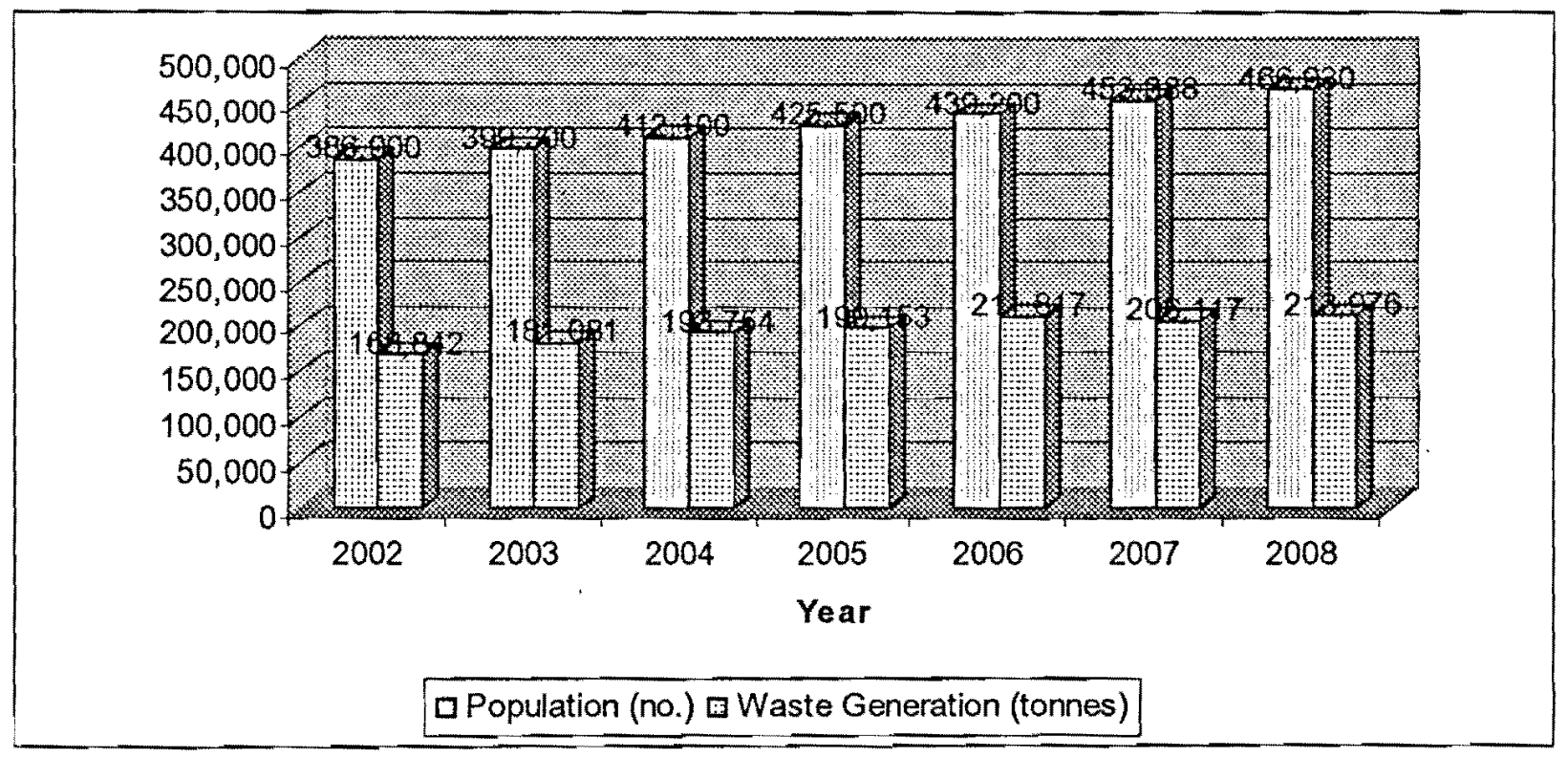

Figure 4.21 Population Growths and Waste Generation

\subsubsection{Waste Generations Per Capita}

In the Region of Halton waste generation per capita was $434 \mathrm{Kg}$ in 2002 and increased through the year 2003 to $467 \mathrm{Kg}$ in 2004 . Waste generation decreased to $466 \mathrm{Kg}$ in 2005 with a rise to $482 \mathrm{Kg}$ in 2006 . Waste generation again decreased to $455 \mathrm{Kg}$ in 2007 and increased to $458 \mathrm{Kg}$ in 2008. The trend of waste generation per capita is shown in Figure 4.22. The historical trend of 
per capita waste generation shows a significant reduction of $458 \mathrm{Kg}$ in 2008 from the highest value of $482 \mathrm{Kgm}$ in 2006 during 2002-2008.

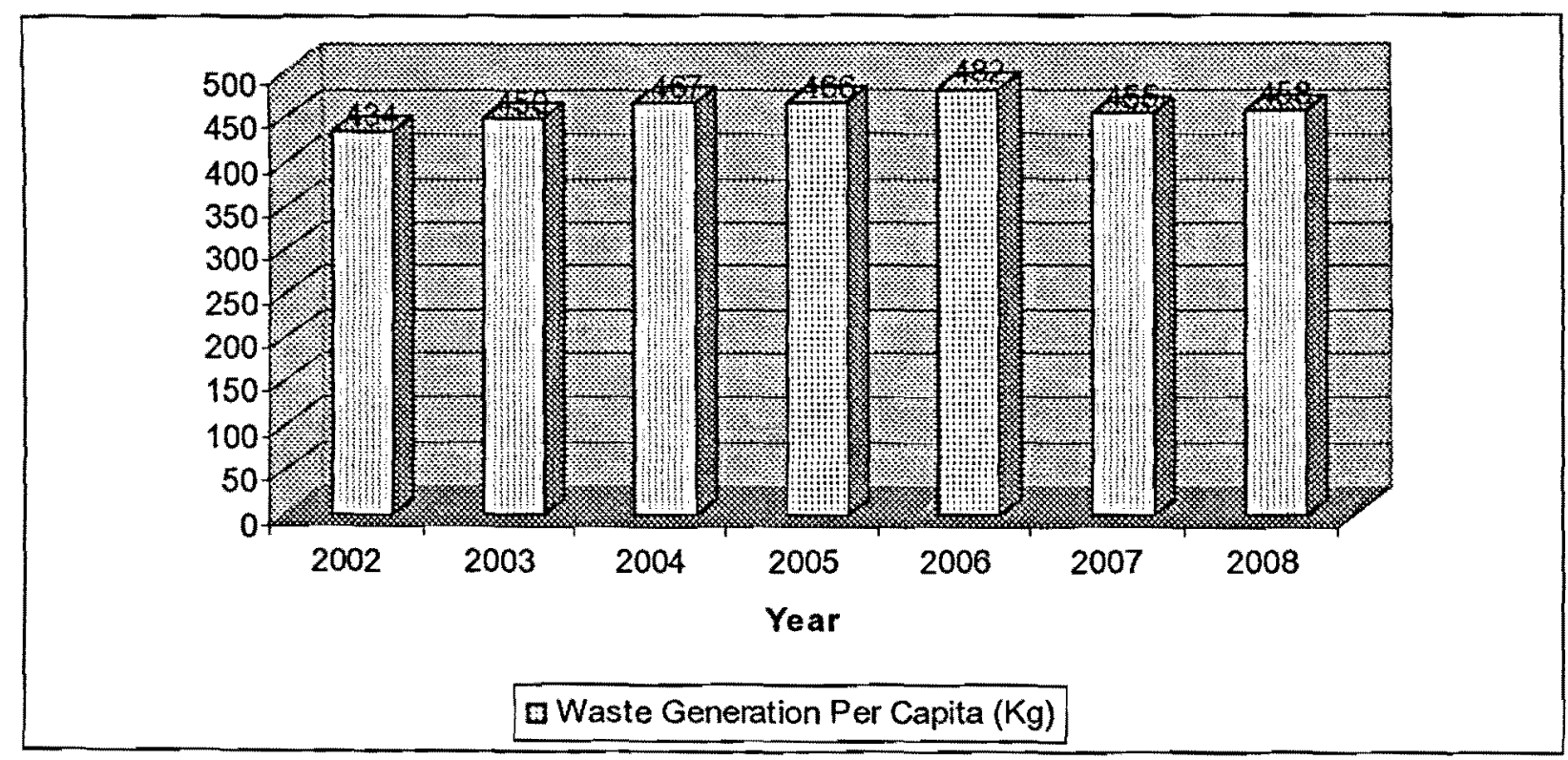

Figure 4.22 Waste Generations Per Capita

\subsection{Regional Municipality of Peel}

\subsubsection{Waste Management in the Year 2002}

\subsubsection{Disposal of Garbage}

In the year 2002, a total of 61,869 tonnes of waste was landfilled to Caledon Sanitary Landfill site which included residential waste 44,320 tonnes, Depots/CRC's/EDE waste 2,293 tonnes, KMS-residues 8,424 tonnes, blue/grey residue 6,209 tonnes and organics residue 623 tonnes. A total of 43,584 tonnes of waste was exported to Michigan for disposal which included residential waste 38,156 tonnes, KMS-residues 5,406 tonnes, and Depot/CRC's 22 tonnes. 114,859 tonnes 
of waste was converted to energy. Finally, a grand total of 220,312 tonnes of waste was disposed of by the Region of Peel as shown in the Table 4.7. This waste represented $55.3 \%$ of the total waste managed.

\section{Table 4.7 Peel Region Waste Disposal}

\begin{tabular}{|l|c|}
\hline Description & Disposal (tonnes) \\
\hline Landfilled & 61,869 \\
\hline Exported & 43,584 \\
\hline Energy from Waste & 114,859 \\
\hline Total & 220,312 \\
\hline
\end{tabular}

Source: Regional Municipality of Peel, 2003

\subsubsection{Waste Diversion}

178,020 tonnes of material was diverted away from disposal by the Region of Peel. The diversion rate for the year 2002 was $44.7 \%$ as shown in the Table 4.8 .

\section{A. Recycling}

In the year $2002,77,432$ tonnes of waste material was diverted through blue $\&$ grey box, 7,679 tonnes from non $\mathrm{B} / \mathrm{G}$ box recycling totalling 85,111 tonnes were diverted from disposal by the Region of Peel as shown in the Table 4.8. Blue box included glass bottles and jars, plastic bottles, plastic food tubs, metal cans, polycot cartons, plastic film, polystyrene foam packaging and empty aerosol and paint cans. Grey box included newspapers, catalogues, magazines, telephone books, household paper, junk mail, envelopes, boxboard, and cardboard. The recycling program represented $21.37 \%$ of the total waste system managed by the Region. 
B. Material Reuse

The Region diverted 2,127 tonnes white goods, 34,983 tonnes bottom ash and metal, 1,538 tonnes household hazardous wastes and 184 tonnes reusable goods from disposal. In total, 38,832 tonnes were diverted from disposal as shown in the Table 4.8 through various re-use and exchange programs. This waste diversion program represented $9.75 \%$ of the waste stream.

C. Leaf, Yard Waste/Organics

In 2002, 31,644 tonnes of leaf \& yard waste, 2,403 tonnes of organics at Peel Organics Composting Project and 1,128 tonnes yard waste/organics collected at Depots/CRC/EDE for a total of 35,175 tonnes were diverted from disposal as shown in the Table 4.8. This waste diversion program represented $8.83 \%$ of the waste stream.

D. Grasscycling arld Backyard Composting

In 2002,2,559 tonnes waste were diverted through grasscycling and 16,343 tonnes were diverted through backyard composting. These two residential composting programs resulted in 18,902 tonnes of organic waste as shown in the Table 4.8 being diverted from collection and disposal. This waste diversion program represented $4.75 \%$ of the waste stream. 
Table 4.8 Region of Pecl Waste Diversion 2002

\begin{tabular}{|l|c|c|}
\hline Program & Tonncs & \% of Total Wastc Nlanagcd \\
\hline Recycling & 85,111 & 21,37 \\
\hline Material Reuse & 38,832 & 9.75 \\
\hline Leaf, Yard Waste/Organics & 35,175 & 8.83 \\
\hline Grasscycling and Backyard Composting & 18,902 & 4.75 \\
\hline Total & 178,020 & 44.7 \\
\hline
\end{tabular}

Source: Regional Municipality of Peel, 2003

E. Diverted Waste Composition

The diverted wastes constituted $48 \%$ recycling materials, 20\% leaf, yard wate/organic $3,22 \%$ re-used materials and $10 \%$ grasscycling and backyard composting matcrials as shown in the Figure 4.23.

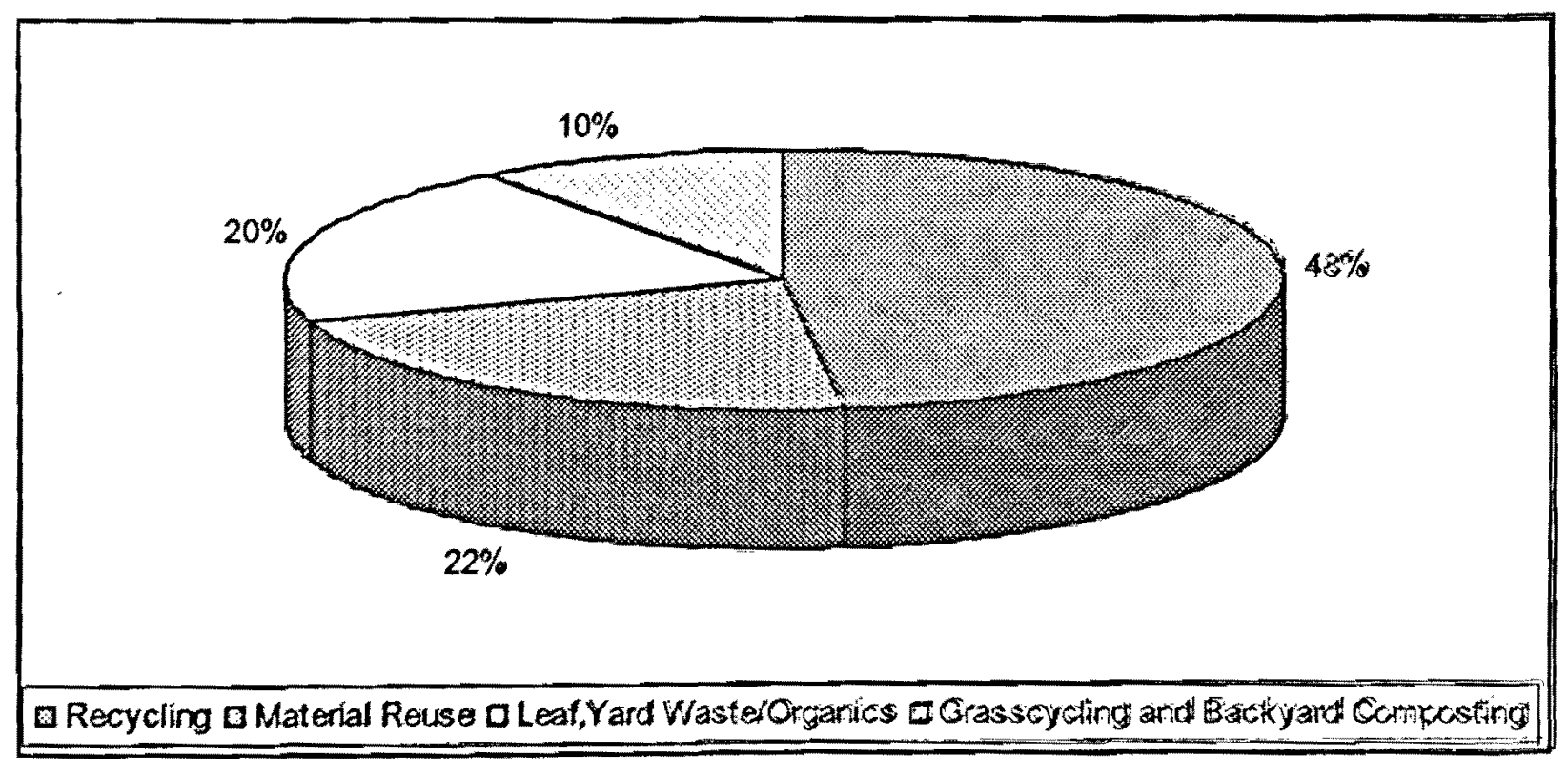

Figure 4.23 Composition of Diverted Waste in 2002 


\subsubsection{Population and Quantity of Waste Managed}

In the year 2002, the population of Peel Region was $1,024,000$, the total quantity of waste managed through different diversion programs and disposal was 398,332 tonnes and the diversion rate was $44.7 \%$ as shown in the Table 4.9 .

Table 4.9 Peel Region 2002 Waste Management

\begin{tabular}{|c|c|c|c|c|}
\hline Population & $\begin{array}{c}\text { Quantity } \\
\text { Managed } \\
\text { (tonnes) }\end{array}$ & $\begin{array}{c}\text { Quantity } \\
\text { Diverted } \\
\text { (tonnes) }\end{array}$ & Diversion Rate & $\begin{array}{c}\text { Waste } \\
\text { Disposed of } \\
\text { (tonnes) }\end{array}$ \\
\hline $1,024,000$ & 398,332 & 178,020 & $44.7 \%$ & 220,312 \\
\hline
\end{tabular}

Source: Regional Municipality of Peel, 2003

\subsubsection{Temporal Trend from 2002-2008}

\subsubsection{Waste Disposal}

In the Region of Peel, waste disposal was composed of landfilled, exported and energy from waste. In the Region, 220,312 tonnes of waste was disposed of in 2002 and gradually increased through the years $2003,2004,2005$ and to 256,907 tonnes in 2006. Waste disposal decreased to 224,521 tonnes in 2007 and increased to 240,003 tonnes in 2008. Waste disposal trend is shown in Figure 4.24. Landfilled disposal decreased by about $50 \%$ from 2002 to 2008 , export increased by about $152 \%$ from 2002 to 2008 and energy from waste decreased by about $13.6 \%$ from 2002 to 2008 . The historical trend of waste disposal shows an increase in total quantity by $8.9 \%$ from 2002 to 2008 but still it shows a reduction in quantity by $6.6 \%$ from the highest quantity in 2006 . This happened due to significant increase of diversion rate in the years 2007 and 2008 . 


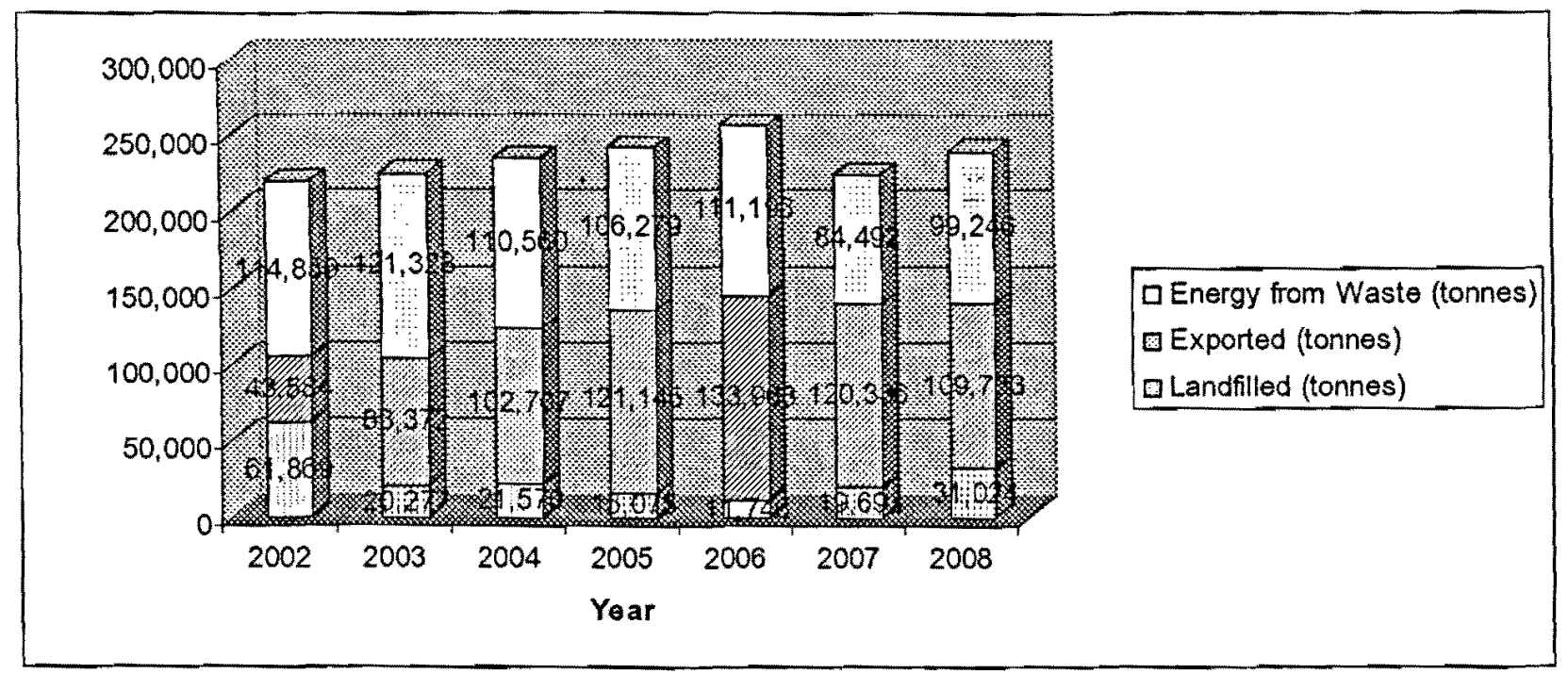

\section{Figure 4.24 Waste Disposal of Peel Region}

\subsubsection{Waste Diversion}

The diversion rate was $44.7 \%$ in 2002 and $45.2 \%$ for the years $2003,2004,2005,2006$, and increased to $49.6 \%$ in 2007 and $50.2 \%$ in 2008 . Quantitative diversions through the years 2002 , $2003,2004,2005,2006,2007$ and 2008 were 178,020 tonnes, 185,719 tonnes, 193,955 tonnes, 199,800 tonnes, 212,191 tonnes, 220,661 tonnes and 242,290 tonnes respectively. The diversion trend is shown in Figure 4.25. Historical trend shows a positive diversion trend from 2002 to 2008. The region successfully met the goal of achieving 50\% diversion rate in 2007 as was set in the 1999 Regional Council approved Long Term Waste Management Strategy (LTWMS) Plan. In consistent with the LTWMS, significant improvements and enhancement to the Region's waste management system were incorporated and the required expansion for waste infrastructure was carried out. Finally, the introduction of organics collection program in the Spring of 2007 has contributed ( $6.2 \%$ of the total waste managed) to achieving a diversion rate $50.2 \%$ in 2008. 


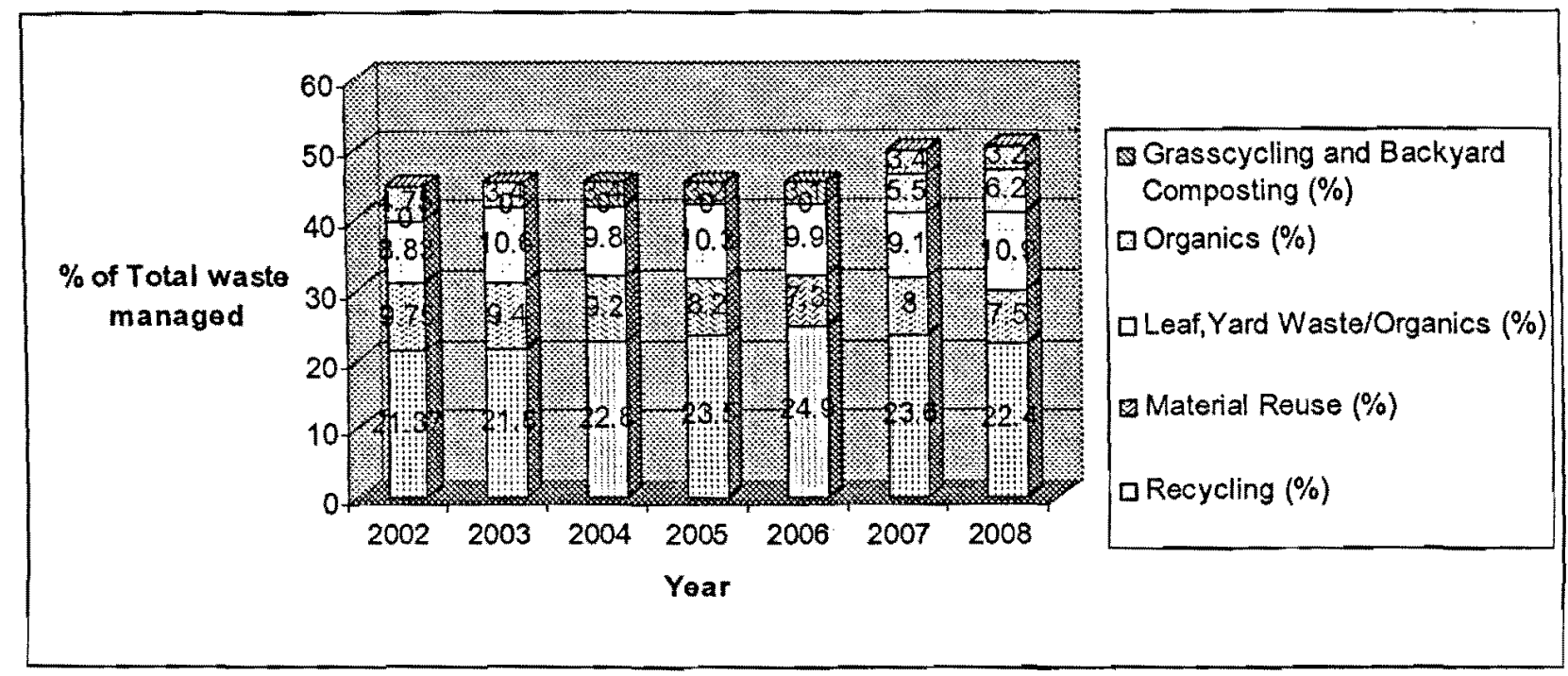

Figure 4.25 Waste Diversion of Peel Region

\subsubsection{Diverted Waste Composition}

Changes in diverted waste compositions from 2003 to 2008 are shown in Figures 4.26 to 4.31. Since inception of the program i.e. from 2007 , organics program increased from $11 \%$ to $12 \%$ in 2008. Grass cycling \& backyard composting decreased from $8 \%$ in 2003 to $6 \%$ in 2008 which was $10 \%$ in 2002 . Recycling decreased from $48 \%$ in 2003 to $45 \%$ in 2008 which was also $48 \%$ in 2002. Material reuse program decreased from $21 \%$ in 2003 to $15 \%$ in 2008 which was $22 \%$ in 2002. Leaf \& yard waste/organics program decreased from $23 \%$ in 2003 to $22 \%$ in 2008 which was $20 \%$ in 2002 . 


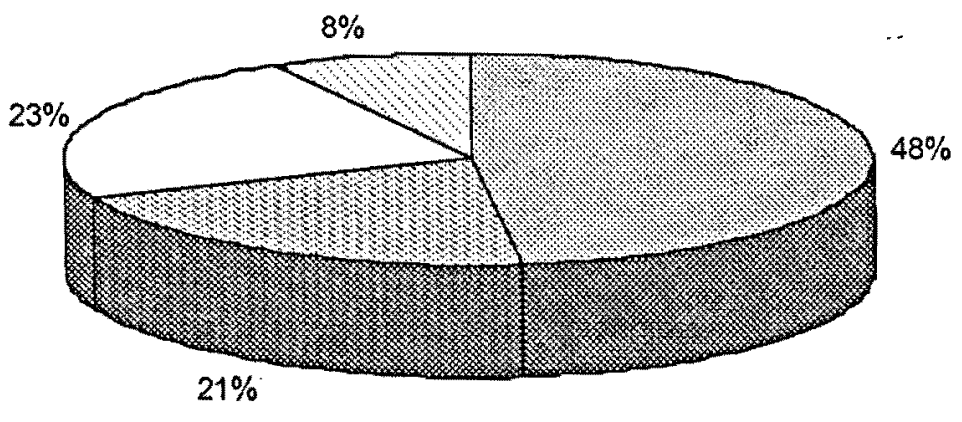

Recycling

$\square$ Material Reuse

口 Leaf,Yard Waste/Organics

- Grasscycling and Backyard Composting

Figure 4.26 Composition of Diverted Waste in 2003

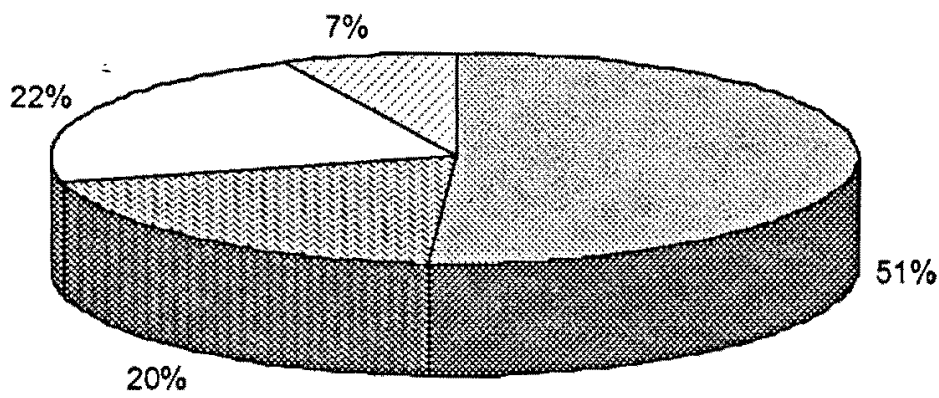

Recycling

Gaterial Reuse

$\square$ Leaf,Yard Waste/Organics

$\square$ Grasscycling and Backyard

Composting

Figure 4.27 Composition of Diverted Waste in 2004 


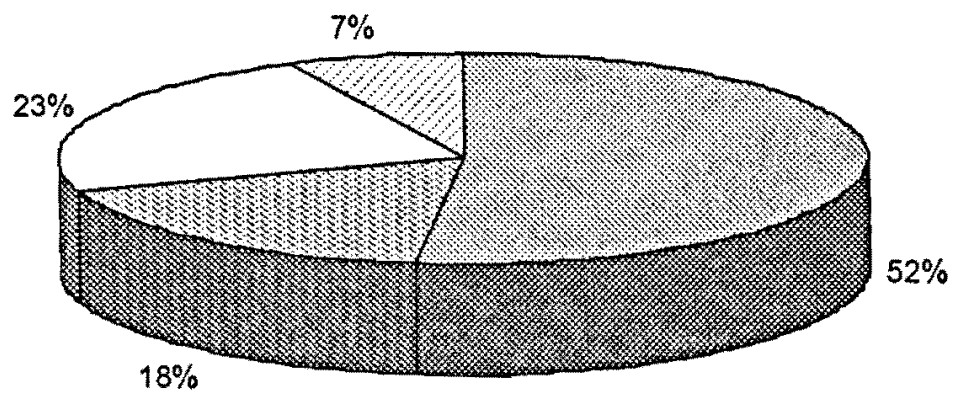

م. Recycling

B Material Reuse

口Leaf,Yard Waste/Organics

$\square$ Grasscycling and Backyard Composting

\section{Figure 4.28 Composition of Diverted Waste in 2005}

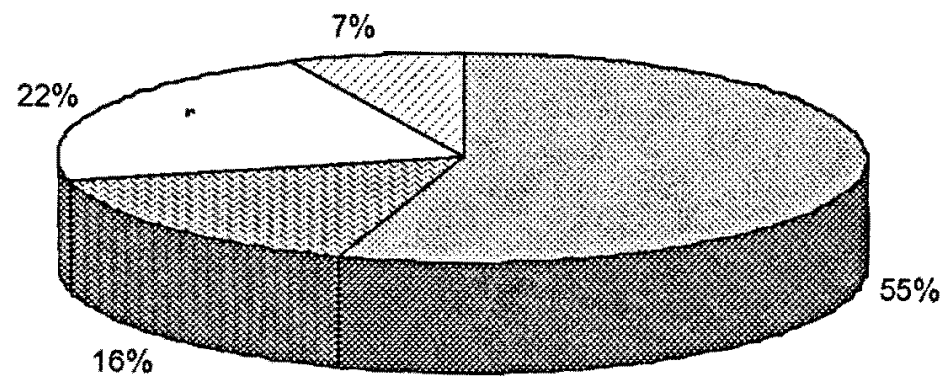

§a Recycling

Material Reuse

$\square$ Leaf, Yard Waste/Organics

$\square$ Grasscycling and Backyard Composting

Figure 4.29 Composition of Diverted Waste in 2006 


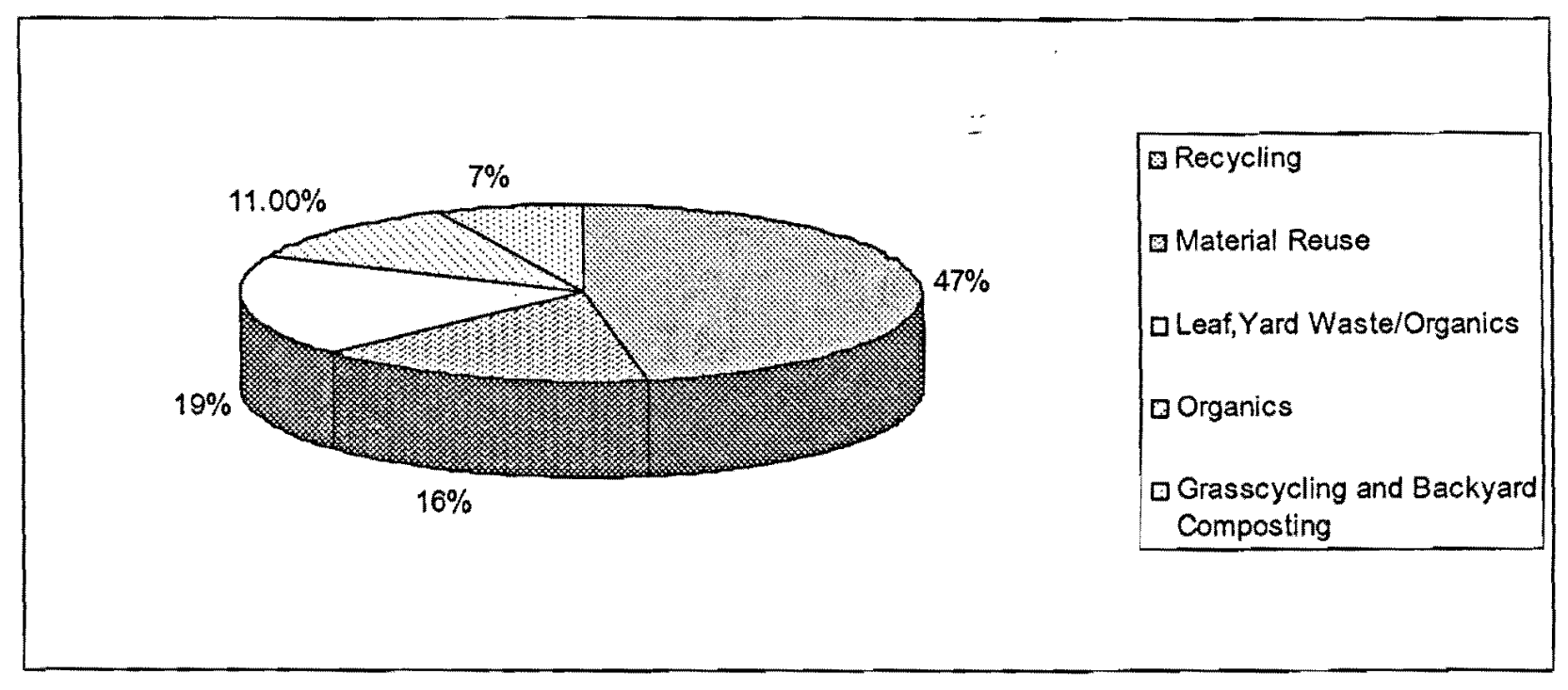

Figure 4.30 Composition of Diverted Waste in 2007

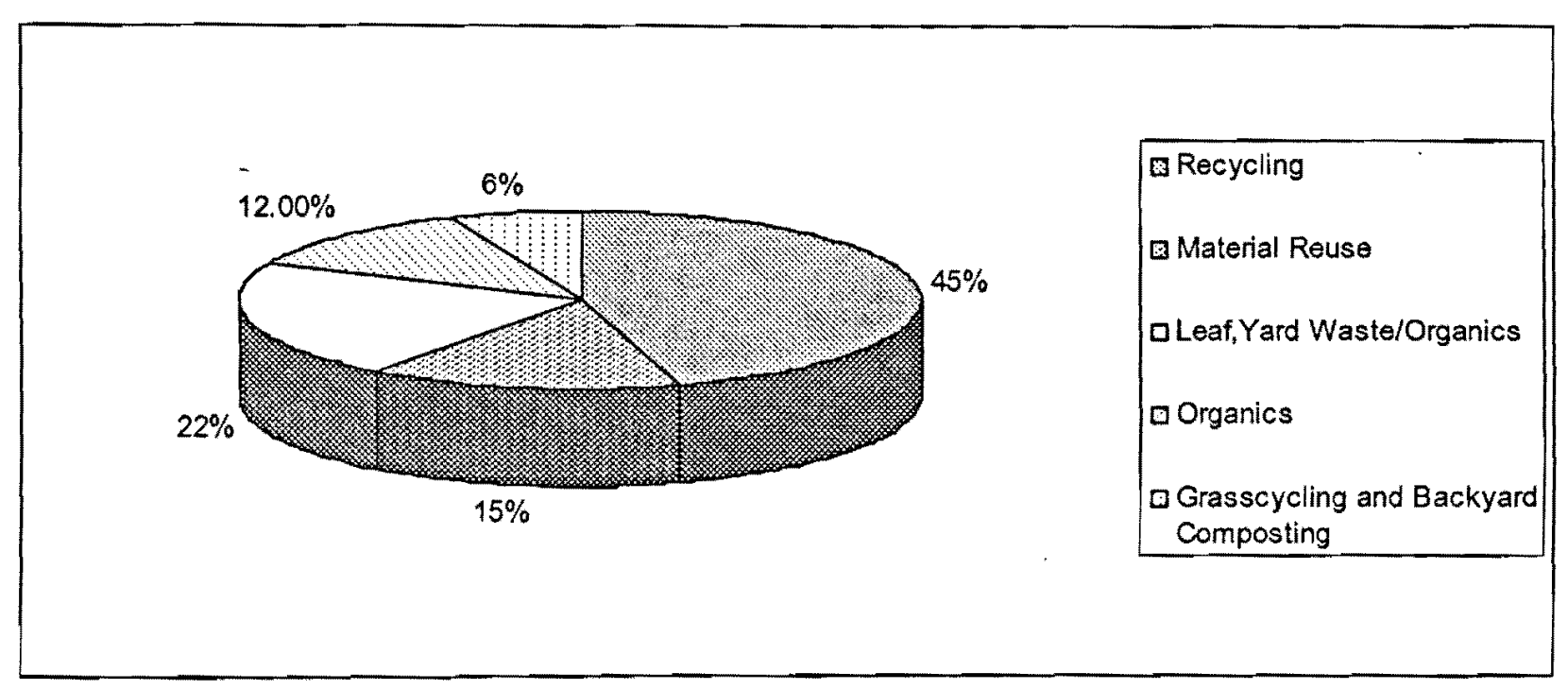

Figure 4.31 Composition of Diverted Waste in 2008 


\subsubsection{Population and Waste Generation}

Population of Peel Region was 1,024,000 in 2002 and increased gradually through 2003, 2004, 2005,2006 and 2007 to $1,200,000$ in 2008 . Waste generation also grew from 398,332 tonnes in 2002 through 2003,2004 , and 2005 to 469,098 tonnes in 2006 with a decrease to 445,182 tonnes in 2007 and a rise again to 482,293 tonnes in 2008 . The trends of population growth and waste generation are shown in Figure 4.32.

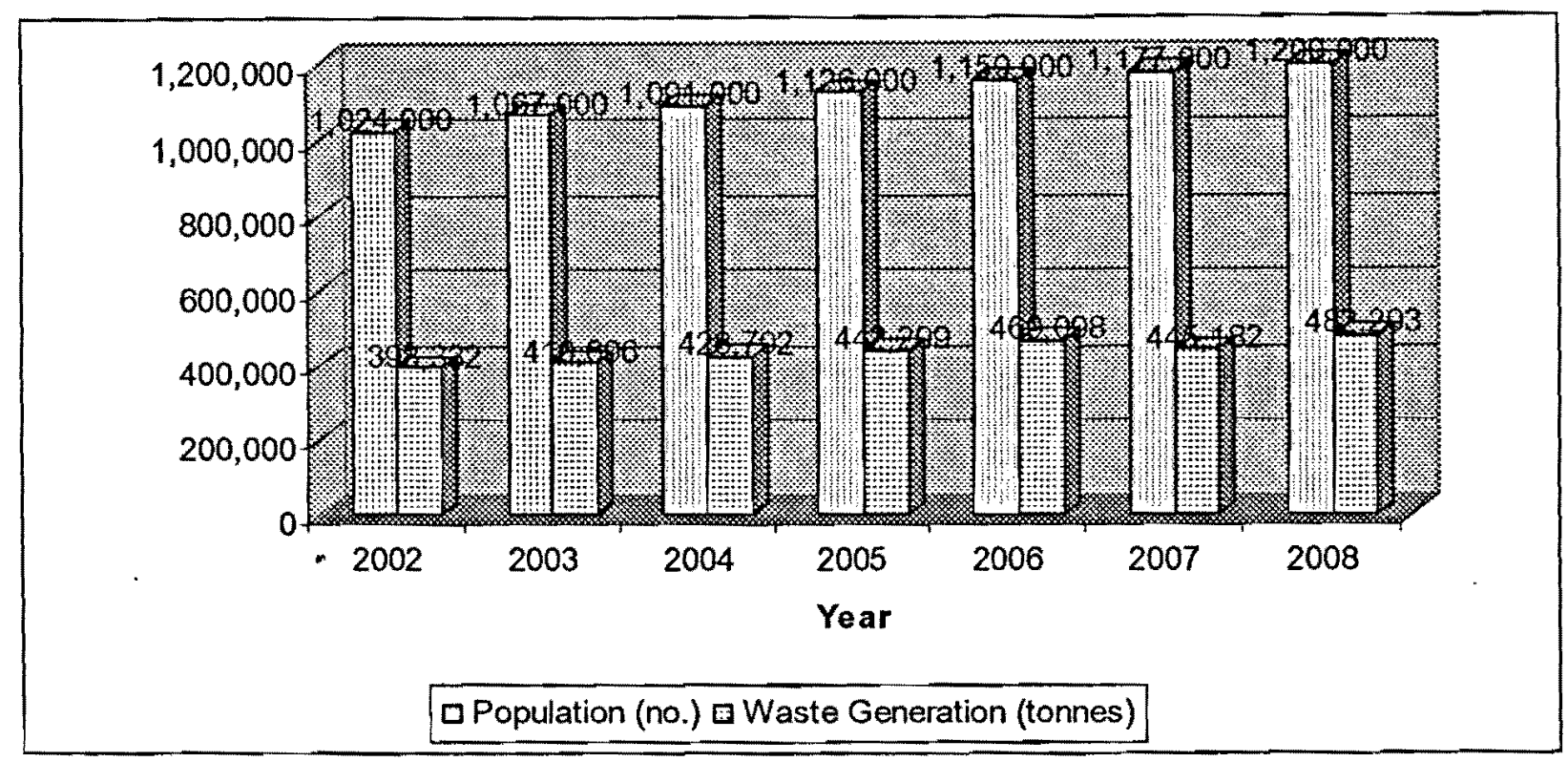

Figure 4.32 Population Growths and Waste Generation

\subsubsection{Waste Generations Per Capita}

In the Region of Peel waste generation per capita was $389 \mathrm{Kg}$ in 2002 and decreased to $385 \mathrm{Kg}$ in 2003. Waste generation per capita increased to $393 \mathrm{Kg}$ in 2004 and remained the same for the year 2005 and increased again to $405 \mathrm{Kg}$ in 2006 . Waste generation per capita decreased to 378 $\mathrm{Kg}$ in 2007 and increased to $402 \mathrm{Kg}$ in 2008 . The trend of waste generation per capita is shown in Figure 4.33. The historical trend of per capita waste generation shows a significant reduction 
of $378 \mathrm{Kg}$ in 2007 from the highest value of $405 \mathrm{Kg}$ in 2006 during 2002-2008. This happened due to the fact that although population growth increased by $1.6 \%$ from 2006 to 2007 , waste generation did not increase like other years, instead, it decreased by $5.1 \%$ at that time. On the whole, waste generation per capita increased by $3.3 \%$ from 2002 to 2008 .

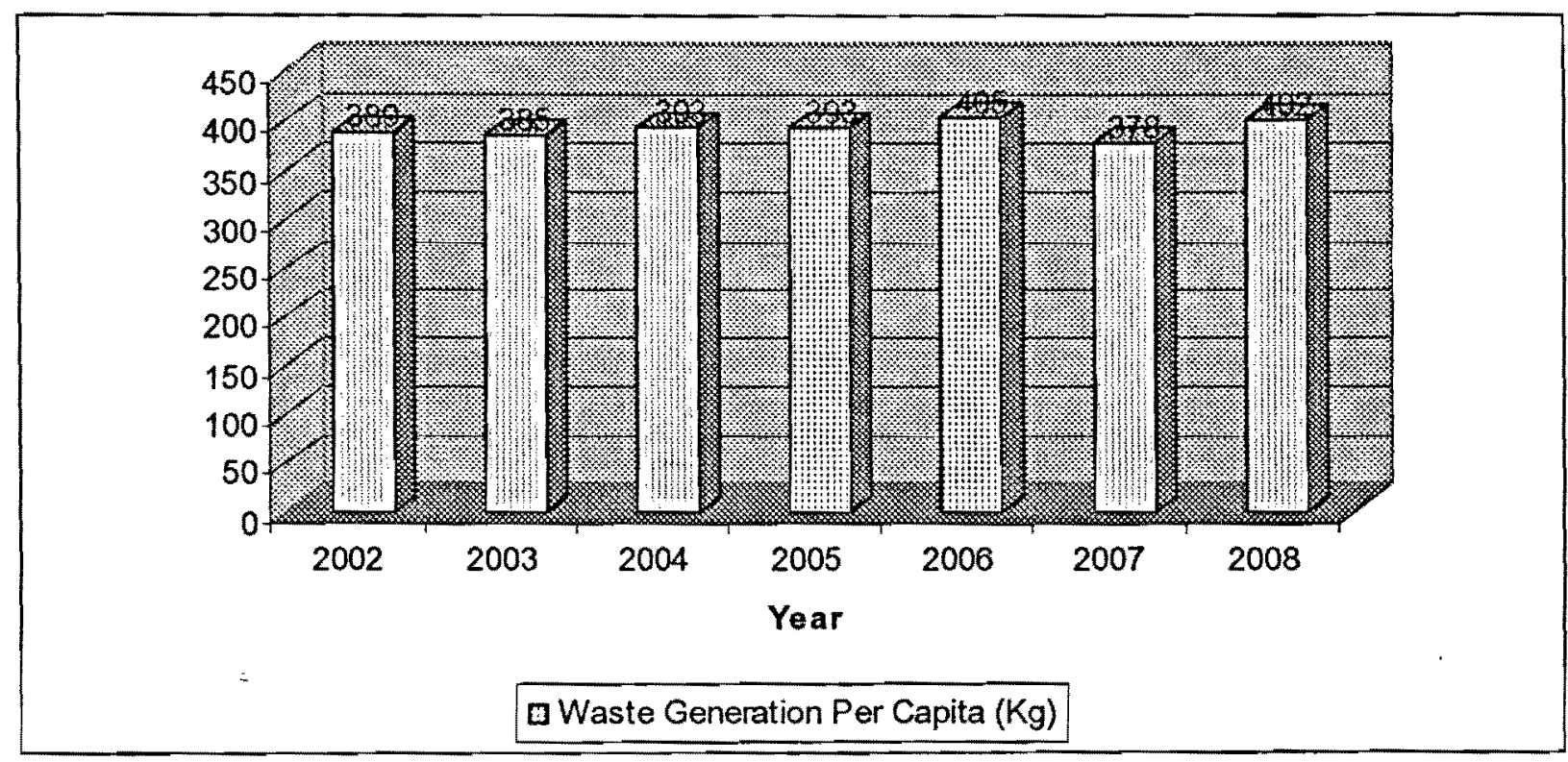

Figure 4.33 Waste Generations Per Capita

\subsection{Regional Municipality of York}

\subsubsection{Waste Management in the Year 2002}




\subsubsection{Disposal of Waste}

In the year 2002, the Keele Valley landfill site was closed. 208,534 tonnes of residual waste (garbage) and 1,952 tonnes of blue box (residue to landfill) were collected at the Area Municipalities. A total of 210,486 tonnes were exported to Green Lane Environmental Landfill (Ontario), Onyx Landfill (Michigan), and Republic Landfill (Michigan) by the Regional Municipality of York for disposal in the year 2002 as shown in the Table 4.10. This waste represented $76.24 \%$ of the total waste managed.

Table-4.10 York Region 2002 Waste Landfilled

\begin{tabular}{|c|c|c|}
\hline \multicolumn{1}{|c|}{ Description } & $\begin{array}{c}\text { Garbage Waste } \\
\text { (tonnes) }\end{array}$ & $\begin{array}{c}\text { Landfilled } \\
\text { (tonnes) }\end{array}$ \\
\hline Residual waste (Garbage) collection & 208,534 & 208,534 \\
\hline Blue box (residue to landfill) & 1,952 & 1,952 \\
\hline Total & 210,486 & 210,486 \\
\hline
\end{tabular}

Source: Regional Municipality of York, 2009

\subsubsection{Waste Diversion}

65,601 tonnes of material was diverted away from disposal by the Region of York. The diversion rate for the year 2002 was $23.76 \%$ as shown in the Table 4.11 . 


\section{A. Recycling}

In the year $2002,49,724$ tonnes of recyclables were diverted through blue box from disposal by the Region of York as shown in the Table 4.11. Blue box included fibre, plastic, metal containers, glass containers, etc. The recycling program represented $18.01 \%$ of the total waste managed by the Region.

B. Material Reuse

The Region diverted 611 tonnes scrap metal, 70 tonnes tires and clean fills, and 1,112 tonnes household hazardous wastes and electronics from disposal. In total, 1,793 tonnes were diverted from disposal as shown in the Table 4.11 through various re-use and exchange programs. This waste diversion program represented $0.65 \%$ of the total waste managed by the Region.

C. Yard Waste

In 2002, 14,084 tonnes of yard waste was diverted from disposal as shown in the Table 4.11. This waste diversion program represented $5.1 \%$ of the total waste managed by the Region. 
Table 4.11 Waste Diversion in 2002

\begin{tabular}{|l|c|c|}
\hline Program & Tonnes & \% of Total Waste Managed \\
\hline Recycling & 49,724 & 18.01 \\
\hline Material Reuse & 1,793 & 0.65 \\
\hline Yard Waste & 14,084 & 5.1 \\
\hline Total & 65,601 & 23.76 \\
\hline
\end{tabular}

Source: Regional Municipality of York, 2009

D. Diverted Waste Composition

The diverted wastes constituted $76 \%$ recycling materials, $21 \%$ yard waste, and $3 \%$ re-used materials as shown in the Figure 4.34.

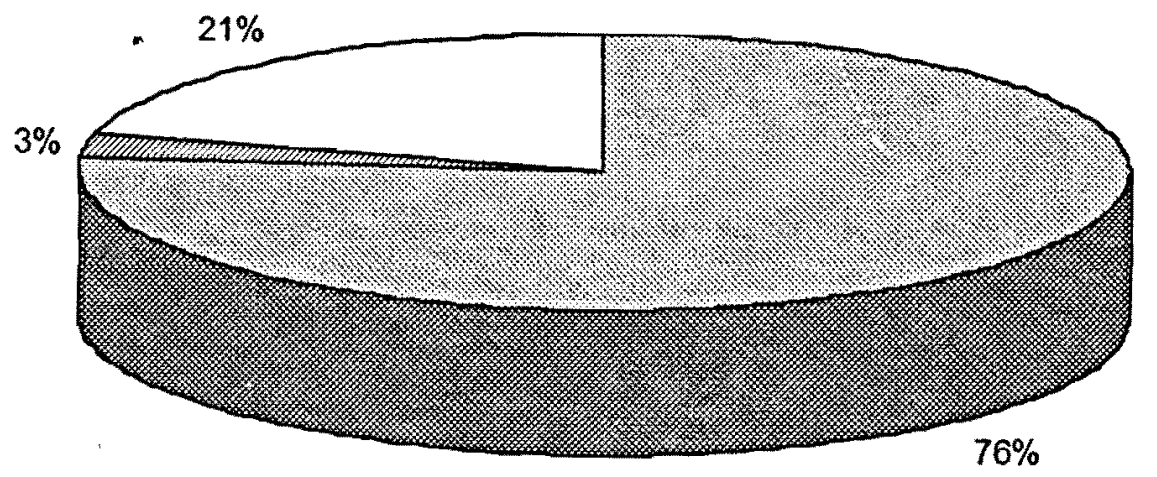




\subsubsection{Population and Quantity of Waste Managed}

In the year 2002, the population of York Region was 798,798 , the total quantity of waste managed through different diversion programs and disposal was 276,087 tonnes and the diversion rate was $23.76 \% \%$ as shown in the Table 4.12 .

Table 4.12 York Region 2002 Waste Management

\begin{tabular}{|c|c|c|c|c|}
\hline Population & $\begin{array}{c}\text { Quantity } \\
\text { Managed } \\
\text { (tonnes) }\end{array}$ & $\begin{array}{c}\text { Quantity } \\
\text { Diverted } \\
\text { (tonnes) }\end{array}$ & Diversion Rate & $\begin{array}{c}\text { Waste } \\
\text { Disposed of } \\
\text { (tonnes) }\end{array}$ \\
\hline 798,798 & 276,087 & 65,601 & $23.76 \%$ & 210,486 \\
\hline
\end{tabular}

Source: Regional Municipality of York, 2009

\subsubsection{Temporal Trend from $2002-2008$}

\subsubsection{Waste Disposal}

In the Region of York, waste disposal was composed of Residual waste (Garbage) collection and Blue box (residue to landfill). In the Region, 210,486 tonnes of waste was disposed of in 2002 and gradually increased through the year 2003 to 228,698 tonnes in 2004 . Waste disposal decreased gradually from 2004 through the years 2005,2006 and 2007 to 123,273 tonnes in 2008. Waste disposal trend is shown in Figure 4.35. Residual waste (Garbage) collection decreased by $44.8 \%$ from 2002 to 2008 and blue box (residue to landfill) increased by about $318 \%$ during the same period. The historical trend of waste disposal shows an increase in total quantity by $8.65 \%$ from 2002 to 2004 and a reduction in total quantity by $46.1 \%$ in 2008 from the highest quantity in 2004 . Finally, waste disposal shows decrease in quantity by $41.43 \%$ from 2002 to 2008 . This happened due to significant increase of diversion rate through the years from 2005 to 2008. 


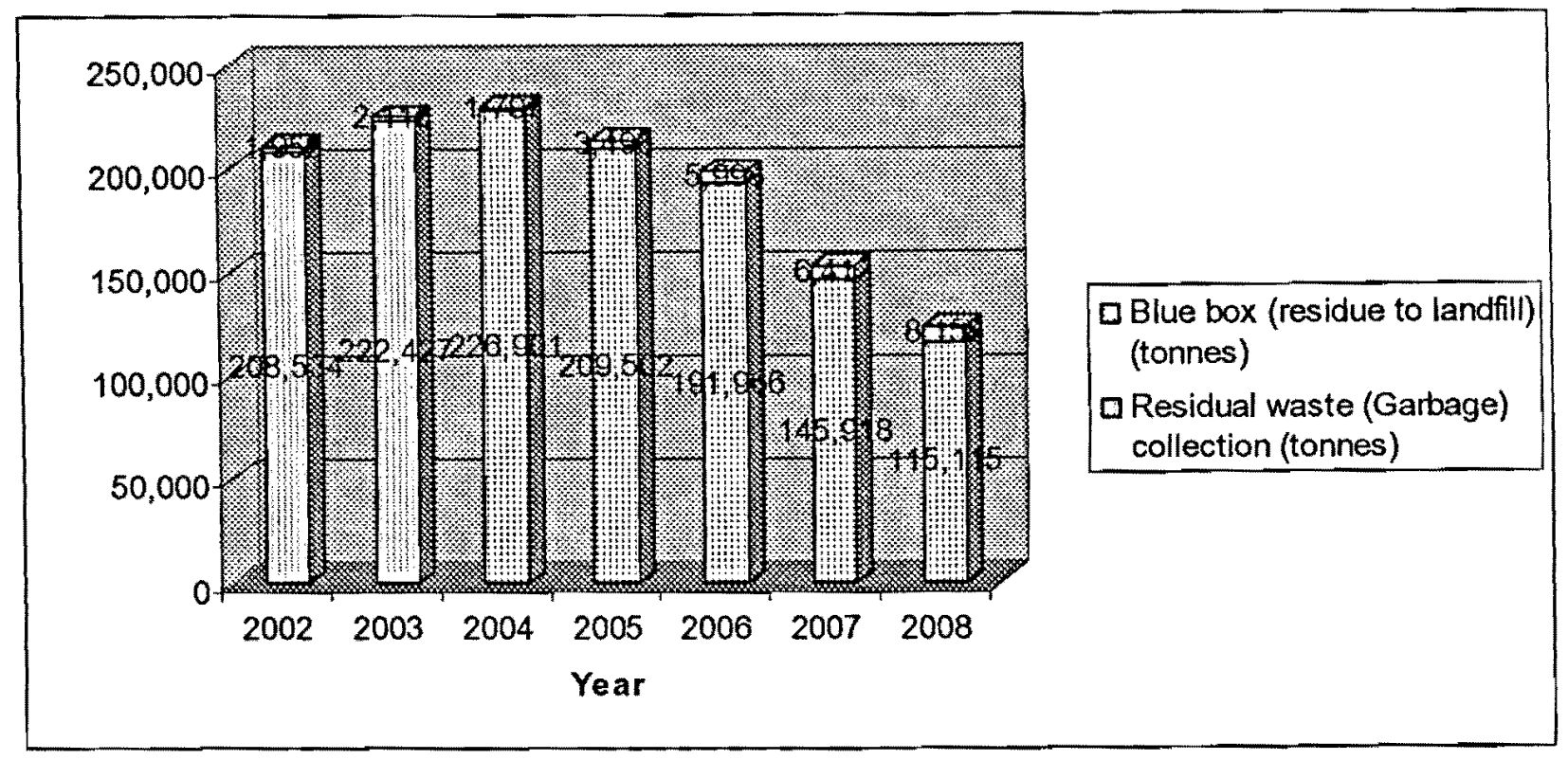

\section{Figure 4.35 Waste Disposal of York Region}

\subsubsection{Waste Diversion}

The diversion rate was $23.76 \%$ in 2002 and gradually increased through the years 2003,2004 , $2005,2006,2007$ and $62.73 \%$ in 2008. Quantitative diversions through the years 2002, 2003, $2004,2005,2006,2007$ and 2008 were 65,601 tonnes, 73,496 tonnes, 81,846 tonnes, 101,128 tonnes, 128,854 tonnes, 167,034 and 207,456 in 2008 respectively. The diversion trend is shown in Figure 4.36. Historical trend shows a positive diversion trend from 2002 to 2008 . The region is successfully approaching to meet the goal of achieving $65 \%$ diversion rate in 2010 as was set in the 2006 Joint Waste Diversion Strategy. It is evident from the figure that the introduction of source separated organics program in 2004 played a significant role in increasing diversion rates through the years 2005, 2006, 2007 and 2008. The continued promotion of Region's waste management programs including household SSO collection, optimized blue box recycling, weekly collection and different promotion and education activities resulted in significant increase of waste diversion rate to $62.73 \%$ in 2008 from $32.19 \%$ in 2005 . 


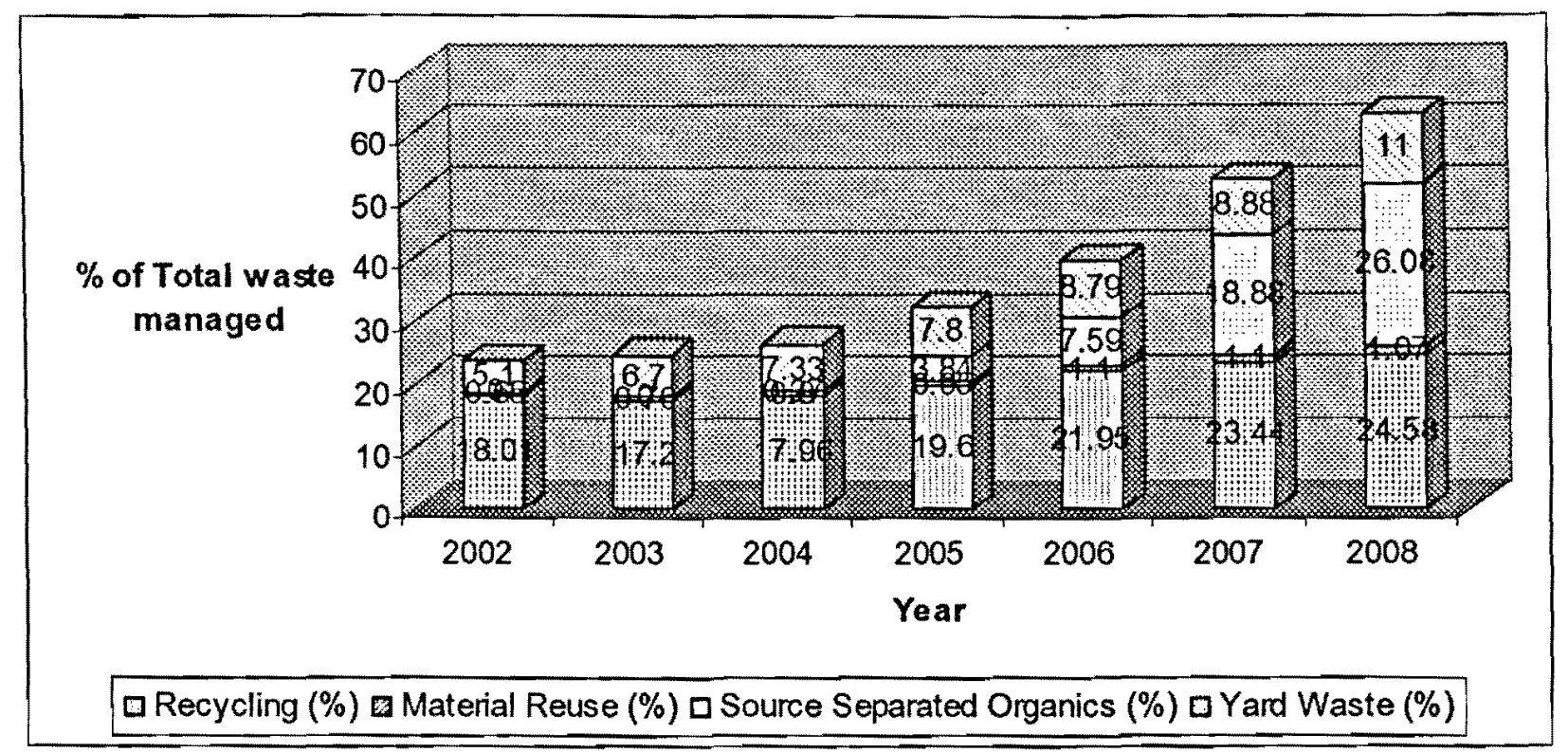

Figure 4.36 Waste Diversion of York Region

\subsubsection{Diverted Waste Composition}

Changes in diverted waste compositions from 2003 to 2008 are shown in Figures 4.37 to 4.42 .

Since inception of the program i.e. from 2004, source separated organics program increased from $1 \%$ to $12 \%$ in 2005,195 in 2006,365 in 2007 and $42 \%$ in 2008 . Recycling decreased gradually from $70 \%$ in 2003 to $39 \%$ in 2008 which was $76 \%$ in 2002 . Material reuse program decreased from $3 \%$ in 2003 to $2 \%$ in 2008 which was also $3 \%$ in 2002. Yard waste decreased from $27 \%$ in 2003 to $17 \%$ in 2008 which was $21 \%$ in 2002 . 


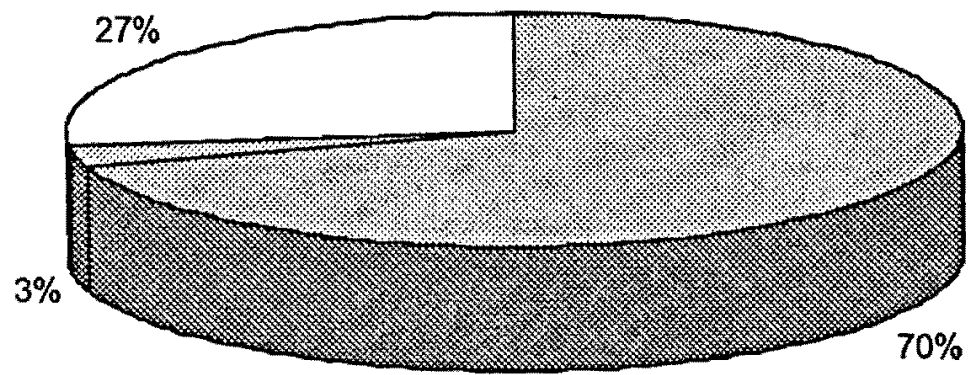

Figure 4.37 Composition of Diverted Waste in 2003

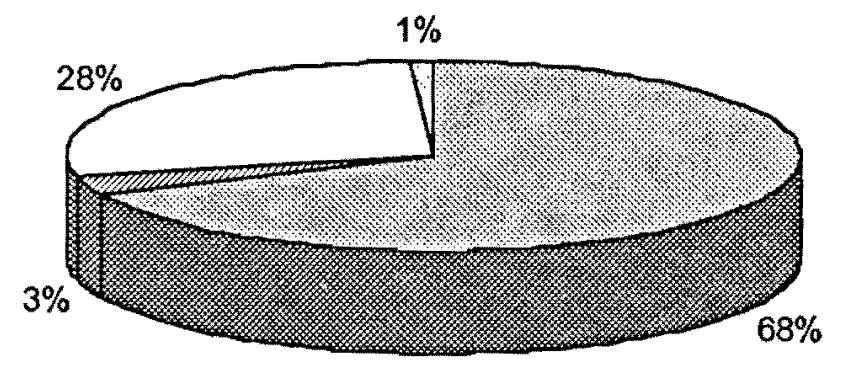

Recycling

Material Reuse

$\square$ Yard Waste

$\square$ Source Separated Organics

Figure 4.38 Composition of Diverted Waste in 2004 


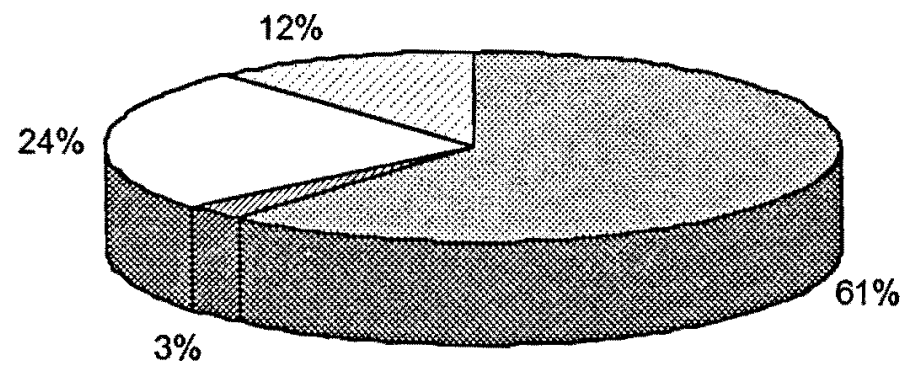

Recycling

Material Reuse

$\square$ Yard Waste

$\square$ Source Separated Organics

Figure 4.39 Composition of Diverted Waste in 2005

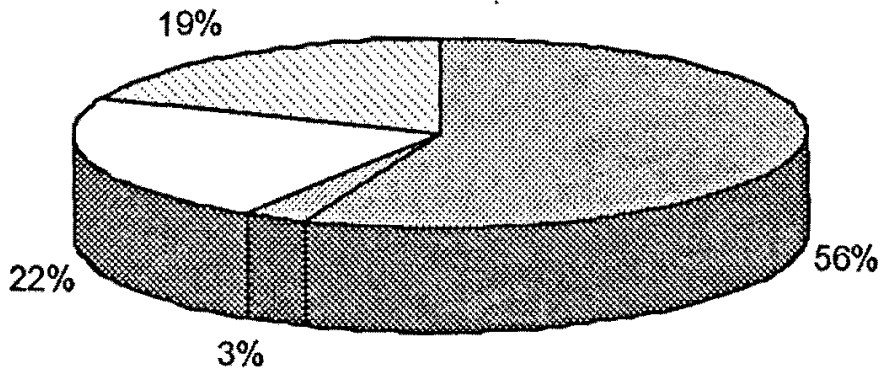

Recycling

Material Reuse

$\square$ Yard Waste

$\square$ Source Separated Organics

Figure 4.40 Composition of Diverted Waste in 2006 


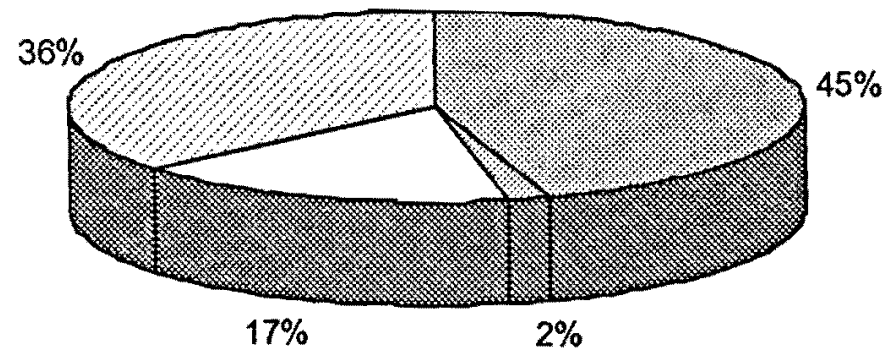

Recycling

Q Material Reuse

$\square$ Yard Waste

$\square$ Source Separated Organics

Figure 4.41 Composition of Diverted Waste in 2007

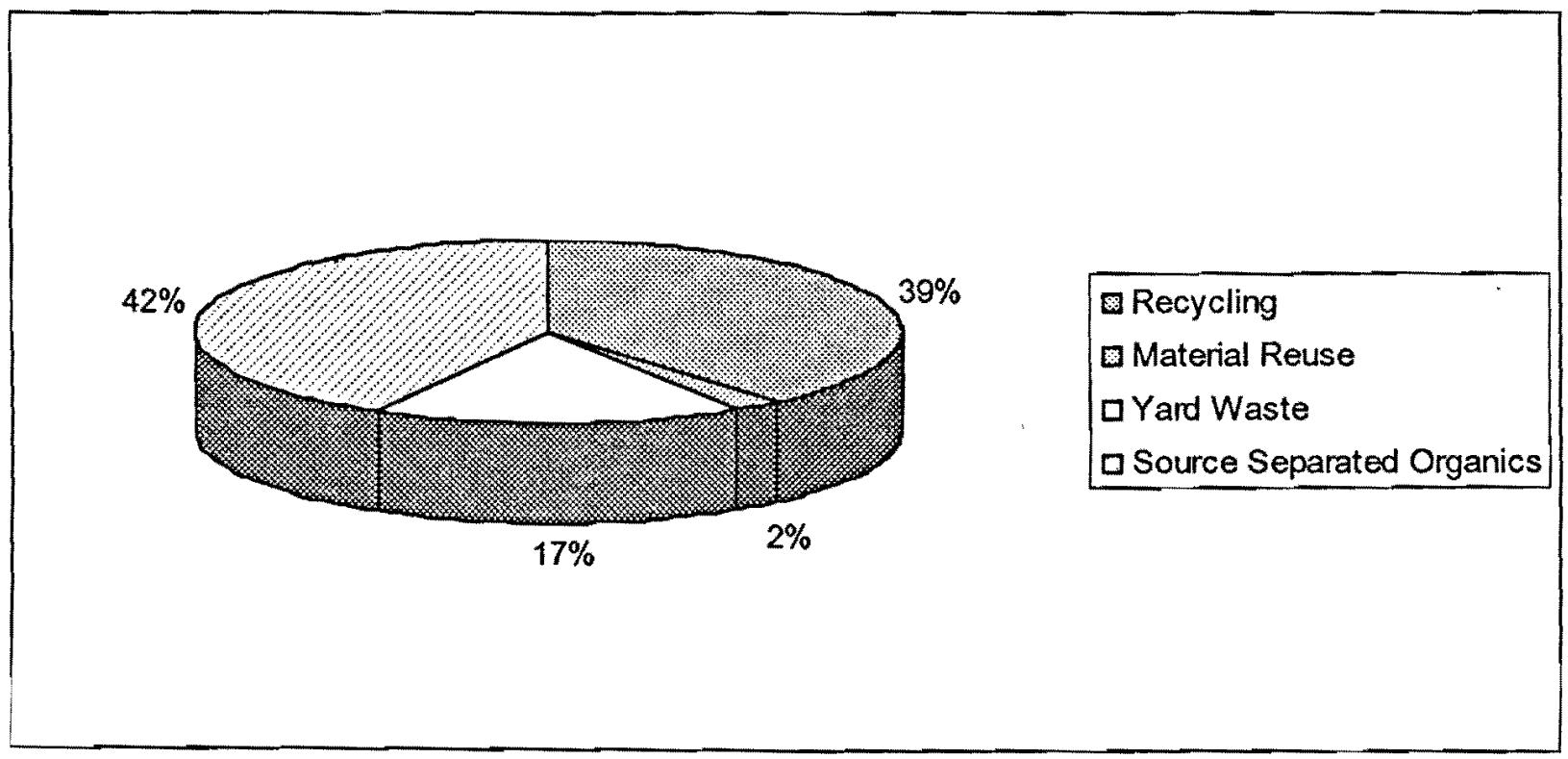

Figure 4.42 Composition of Diverted Waste in 2008 


\subsubsection{Population and Waste Generation}

Population of York Region was 798,798 in 2002 and increased gradually through 2003, 2004, 2005,2006 and 2007 to 1,011360 in 2008 . Waste generation also grew from 276,087 tonnes in 2002 through 2003,2004 , and 2005 to 326,819 tonnes in 2006 with a decrease to 319,365 tonnes in 2007 and a rise again to 330,729 tonnes in 2008 . The trends of population growth and waste generation are shown in Figure 4.43.

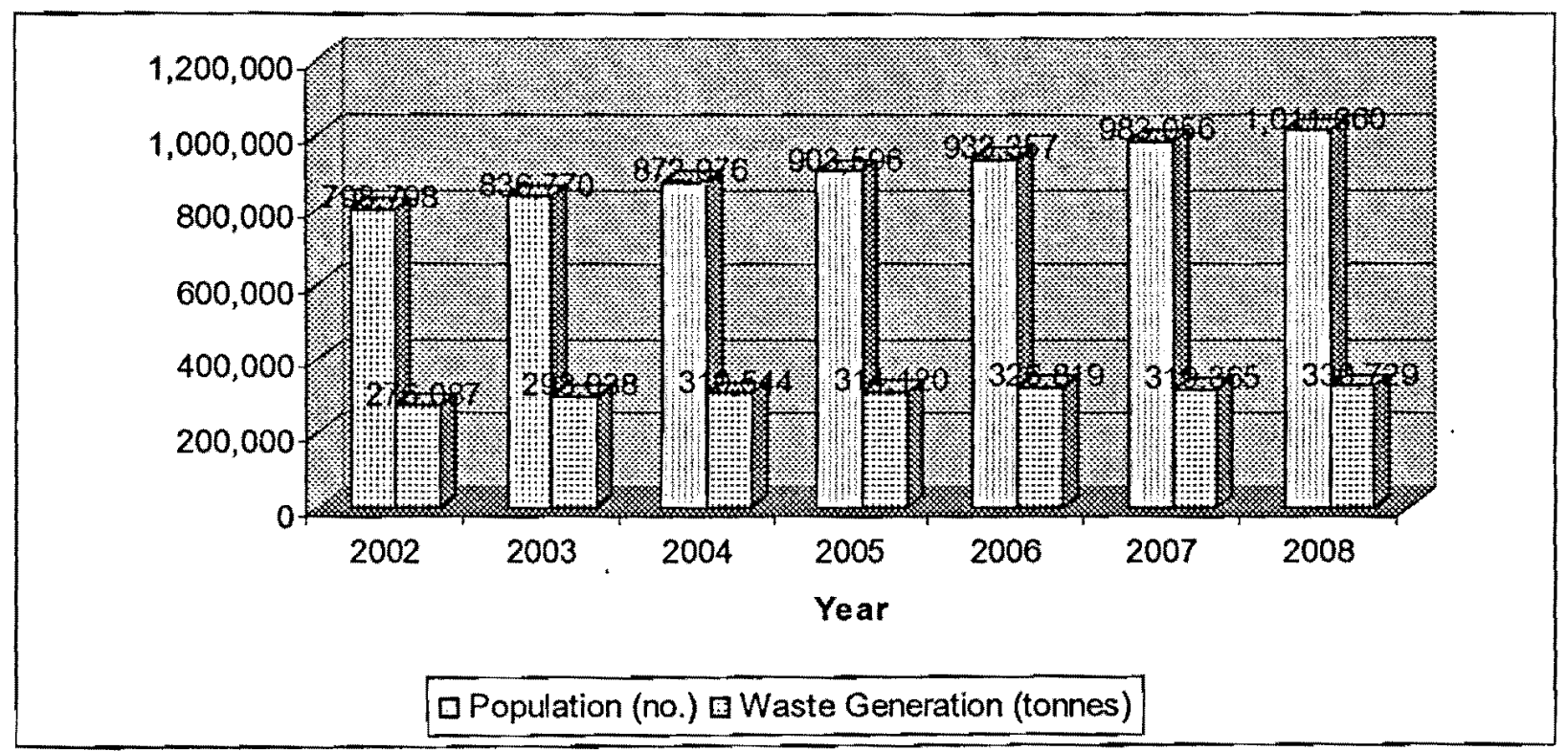

Figure 4.43 Population Growths and Waste Generation

\subsubsection{Waste Generations Per Capita}

In the Region of York waste generation per capita was $346 \mathrm{Kg}$ in 2002 and increased to $356 \mathrm{Kg}$ in 2003 and remained the same for 2004 . Waste generation per capita decreased to $348 \mathrm{Kg}$ in 2005 and increased to $350 \mathrm{Kg}$ in the year 2006. Waste generation per capita decreased to $325 \mathrm{Kg}$ in 2007 and increased to $327 \mathrm{Kg}$ in 2008. The trend of waste generation per capita is shown in Figure 4.44. The historical trend of per capita waste generation shows a significant reduction of 
$325 \mathrm{Kg}$ in 2007 from the highest value of $356 \mathrm{Kg}$ in 2003 and 2004. Finally, waste generation per capita was decreased by $5.5 \%$ from 2002 to 2008 .

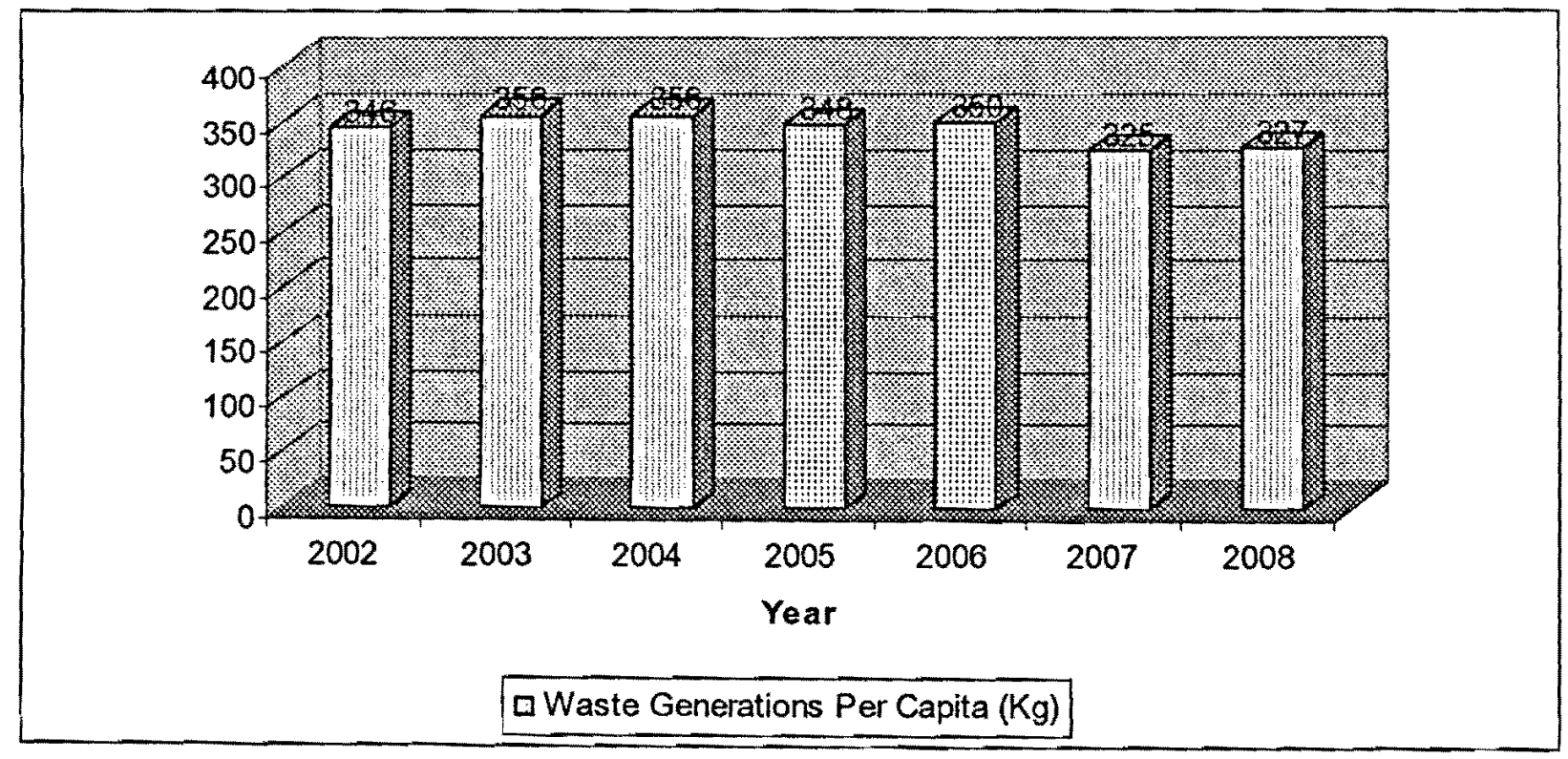

Figure 4.44 Waste Generations Per Capita

\subsection{City of Toronto}

\subsubsection{Waste Management in the Year 2002}




\subsubsection{Disposal of Residential Garbage}

639,443 tonnes of curbside and multi residential garbage waste as well as unwanted bulky goods were collected in the City of Toronto and disposed of by the City in the year 2002. This waste was hauled to the various Landfill sites including export to Michigan for disposal. This was a decrease of 31,619 tonnes over the previous year. This waste represented $72 \%$ of the total waste managed by the City.

\subsubsection{Waste Diversion}

A total of 247,359 tonnes of material was diverted away from the landfill disposal by the City of Toronto. The diversion rate for the year 2002 was $28 \%$ as shown in the Table 4.13 .

A. Blue/Grey Box Recycling

In the year 2002, 134,623 tonnes of waste material was diverted from landfill through curbside and apartment recycling program as shown in the Table 4.13. Recyclables included cardboard cans, plastic food jars, tubs \& lids, plastic bottles \& jugs, milk/juice cartons, empty paint cans \& lids, metal cans, glass bottles \& jars, rigid aluminum trays, pie plates \& roasting pans, drink boxes, corrugated cardboard, plastic grocery \& retail bags, foam polystyrene, household paper, paper gift wrap \& cards, paper egg cartons, rolls \& bags, empty aerosol cans, newspapers, magazines, catalogues, telephone directories, books etc. The blue/grey box recycling program represented $15.2 \%$ of the total waste managed by the City of Toronto. 


\section{B. Leaf and Yard Waste and Xmas Trees}

In 2002, 69,778 tonnes were collected through leaf and yard waste and xmas trees program and diverted from landfill as shown in the Table 4.13. This waste diversion program represented $7.9 \%$ of the total waste managed by the City of Toronto.

C. Material Reuse

2,112 tonnes of waste material was collected through environment days/depots program, 2,678 tonnes were collected through large appliances/scrap metal program, 781 tonnes were collected through household hazardous waste program and 6,535 tonnes were collected through beer store deposit return program. In total, 12,106 tonnes were diverted from landfill disposal in 2002 as shown in the Table 4.13 . This waste diversion program represented $1.4 \%$ of the total waste managed by the city of Toronto.

D. Grasscycling and Backyard Composting (credits)

Grasscycling is simply leaving the grass clippings on the lawn. Waste diversion credits are earned as a result of municipal bans on collecting grass clippings and the use of backyard composters by the residents. These two residential composting programs i.e. grasscycling 10,085 tonnes and backyard composting 17,791 tonnes resulted in 27,876 tonnes of organic waste as shown in the Table 4.13 being diverted from collection and landfill disposal. This waste diversion program represented $3.1 \%$ of the total waste managed by the city of Toronto in the year 2002. 


\section{E. Green Bin SSO}

In the year 2002, the City of Toronto rolled out the green bin program. 2,976 tonnes of source separated organics waste was diverted from landfills through this program as shown in the Table 4.13. Green bin contained fruits, vegetable scraps, meat, shellfish, fish products, pasta, bread, cereal, dairy products, egg shells, coffee grounds, filters, tea bags, soiled paper towels, soiled food packaging, tissues, paper plates, candies, cookies, cakes, baking ingredients, herbs, spices, household plants including soil, diapers, sanitary products, animal waste, pet food etc. This waste diversion program represented $0.3 \%$ of the total waste managed by the city of Toronto.

\section{Table-4.13 2002 Residential Waste Diversion}

\begin{tabular}{|l|c|c|}
\hline \multicolumn{1}{|c|}{ Type/Program } & Tonnes & \% of Total Waste Managed \\
\hline Blue/Grey Box Recycling & 134,623 & 15.2 \\
\hline Leaf and Yard Waste and Xmas trees & 69,778 & 7.9 \\
\hline Material Reuse & 12,106 & 1.4 \\
\hline Grasscycling and Backyard Composting & 27,876 & 3.1 \\
\hline Green Bin SSO & 2,976 & 0.3 \\
\hline Total & 247,359 & 27.9 \\
\hline
\end{tabular}

Source: Kelleher Environmental, 2009

F. Diverted Waste Composition

The diverted wastes constituted $55 \%$ blue/grey box recycling materials, $28 \%$ leaf and yard waste composting materials, $5 \%$ re-used materials, $11 \%$ grasscycling and composting material and $1 \%$ green bin SSO as shown in the Figure 4.45. 


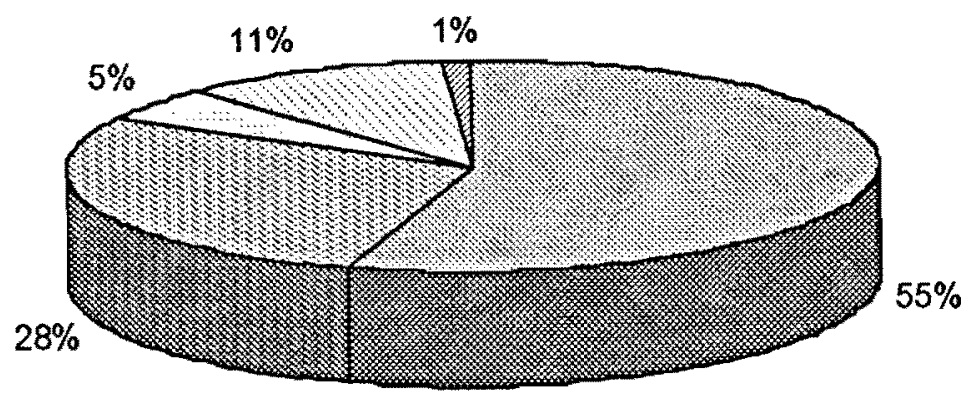

D Blue/Grey Box Recycling

$\square$ Material Reuse

Green Bin SSO
Leaf \& Yard Waste and Xmas trees

$\square$ Grasscycling and Backyard composting

Figure 4.45 Composition of Diverted Waste in 2002

\subsubsection{Population and Quantity of Waste Managed}

In the year 2002, the population of the City of Toronto was $2,620,160$, the total quantity of waste managed through different diversion programs and landfilling was 886,802 tonnes and the diversion rate was $28 \%$ as shown in the Table 4.14 .

Table-4.14 City of Toronto 2002 Waste Management

\begin{tabular}{|c|c|c|c|c|}
\hline Population & $\begin{array}{c}\text { Quantity } \\
\text { Managed } \\
\text { (tonnes) }\end{array}$ & $\begin{array}{c}\text { Quantity } \\
\text { Diverted } \\
\text { (tonnes) }\end{array}$ & Diversion Rate & $\begin{array}{c}\text { Waste } \\
\text { Landfilled } \\
\text { (tonnes) }\end{array}$ \\
\hline $2,620,160$ & 886,802 & 247,359 & $28 \%$ & 639,443 \\
\hline
\end{tabular}

Source: Kelleher Environmental, 2009 


\subsubsection{Temporal Trend from 2002-2008}

\subsubsection{Waste Disposal}

In the City of Toronto, waste disposal was composed of single family residential and multifamily residential programs. In the City, a total of 639,443 tonnes of waste was disposed of in 2002 and gradually decreased through the years $2003,2004,2005,2006,2007$ and to 494,539 tonnes in 2008. Waste disposal trend is shown in Figure 4.46. Single family residential waste decreased by about $12 \%$ from 2005 to 2008 and multi-family residential waste decreased by $0.5 \%$ from 2005 to 2008 . The historical trend of waste disposal shows a significant decrease in total quantity by $22.7 \%$ from 2002 to 2008 . This happened due to gradual increase of diversion rate during $2002-2008$.

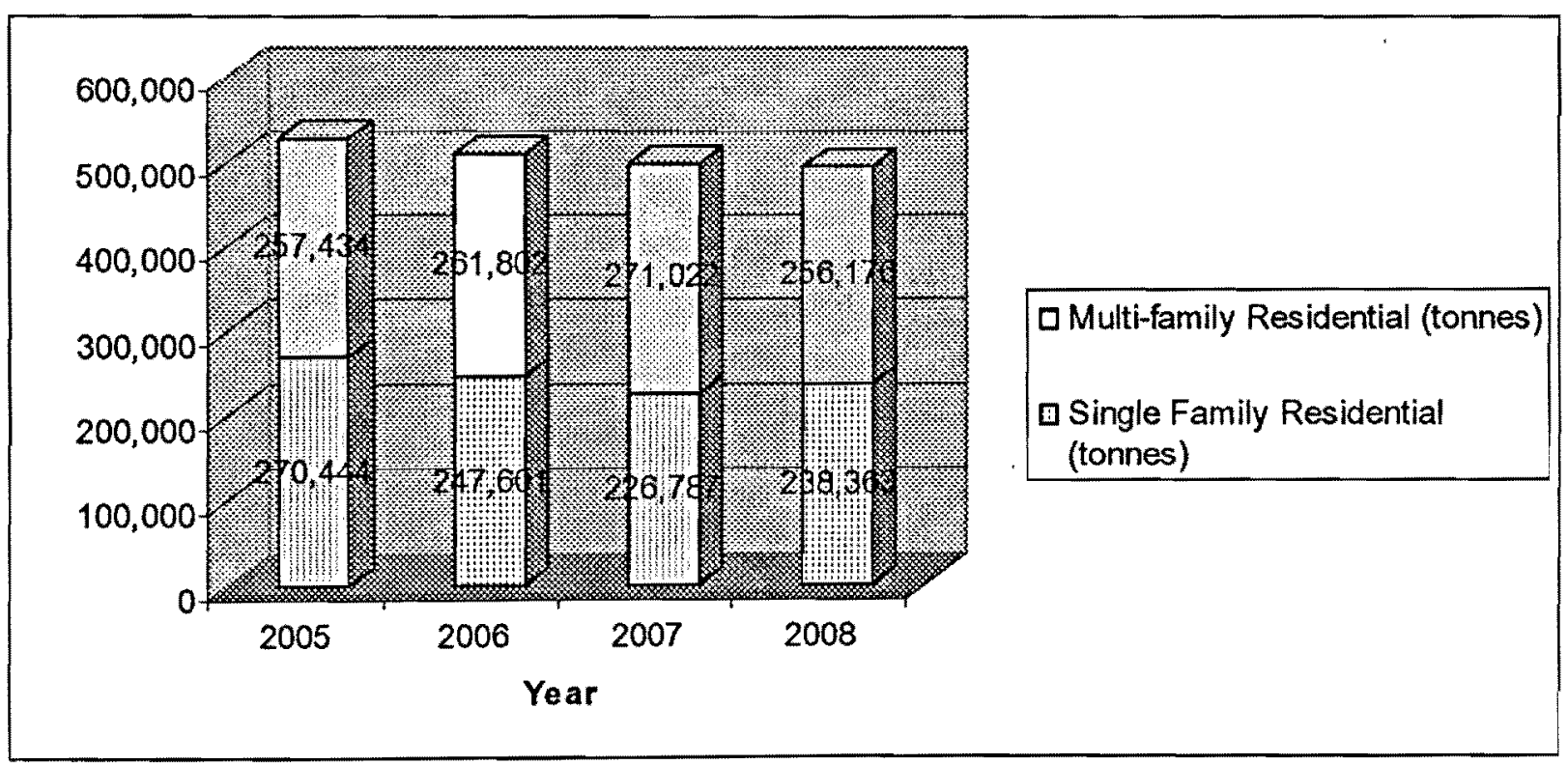

Figure 4.46 Waste Disposal of the City of Toronto 


\subsubsection{Waste Diversion}

The diversion rate was $28 \%$ in 2002 and increased gradually through the years 2003, 2004, 2005, 2006, 2007 and 44\% in 2008. Quantitative diversions through the years 2002, 2003, 2004, 2005, 2006, 2007 and 2008 were 247,359 tonnes, 286,835 tonnes, 310,158 tonnes, 346,150 tonnes, 375,621 tonnes, 367,291 tonnes and 388,188 tonnes respectively. The diversion trend is shown in Figure 4.47. Historical trend shows a positive diversion trend from 2002 to 2008 . The City has exceeded its goal of achieving $30 \%$ diversion rate in 2003 as recommended by the Task Force 2010 and Council adopted it. The continued promotion of City's waste management programs including extensive implementation of green bin SSO Program, Leaf \& Yard Waste and Xmas trees, different promotion and education activities such as media presentations, public presentations, printed materials and other community activities resulted in $44 \%$ diversion rate in 2008 with a committed goal of achieving $70 \%$ waste diversion by 2010 .

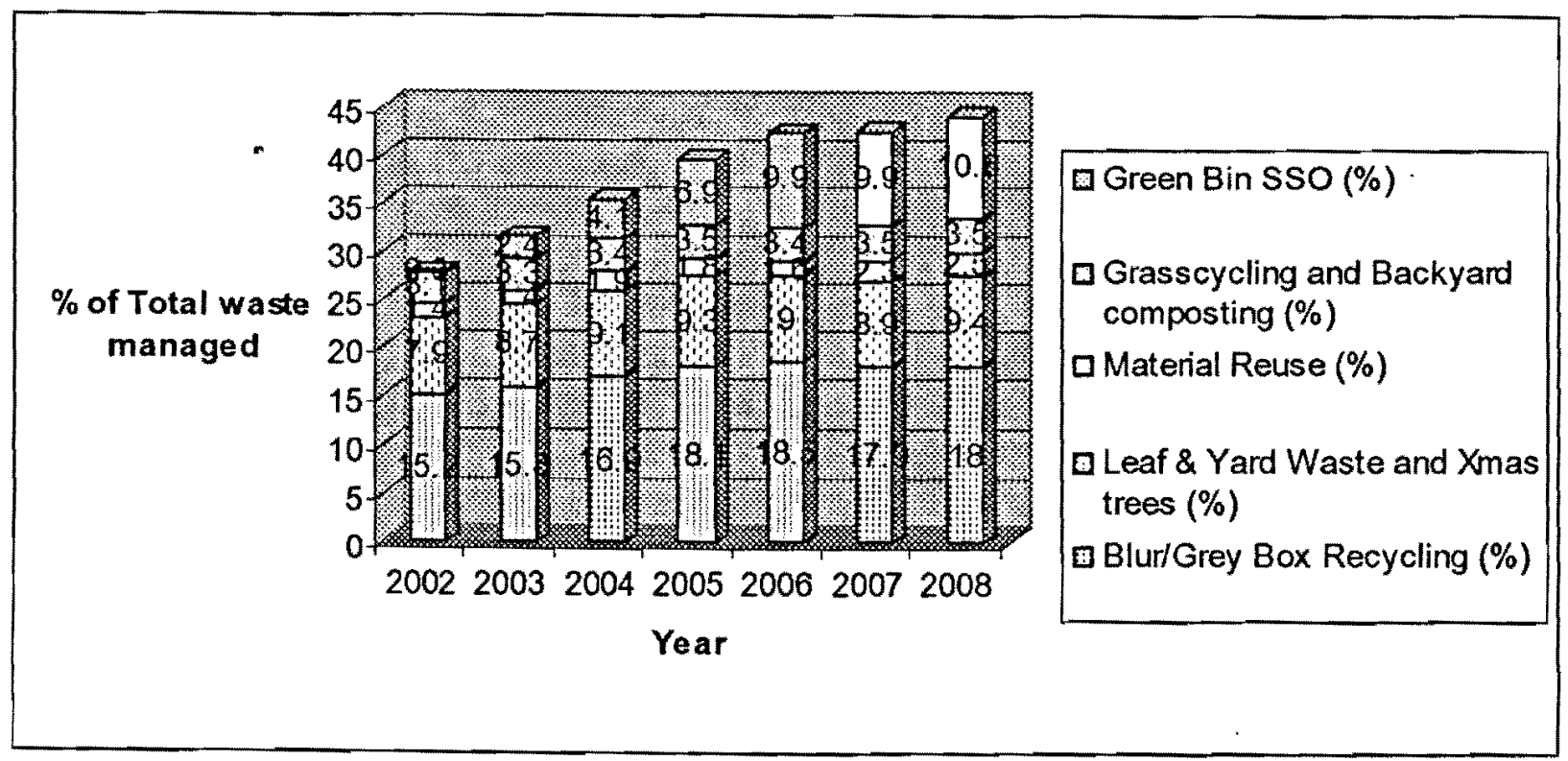

Figure 4.47 Waste Diversion of the City of Toronto 


\subsubsection{Diverted Waste Composition}

Changes in diverted waste compositions from 2003 to 2008 are shown in Figures 4.48 to 4.53 .

Since inception of the program i.e. from 2002 , green bin SSO program increased gradually from $1 \%$ in 2002 to $24 \%$ in 2008 . Grass cycling and backyard composting decreased from $10 \%$ in 2003 to $8 \%$ in 2008 which was $11 \%$ in 2002 . Blue/Grey box recycling gradually decreased from $50 \%$ in 2003 to $41 \%$ in 2008 which was $55 \%$ in 2002 . Material reuse program increased from $5 \%$ in 2003 to $6 \%$ in 2008 which was also $5 \%$ in 2002 . Leaf \& yard waste and Xmas trees decreased from $27 \%$ in 2003 to $21 \%$ in 2008 which was $28 \%$ in 2002 .

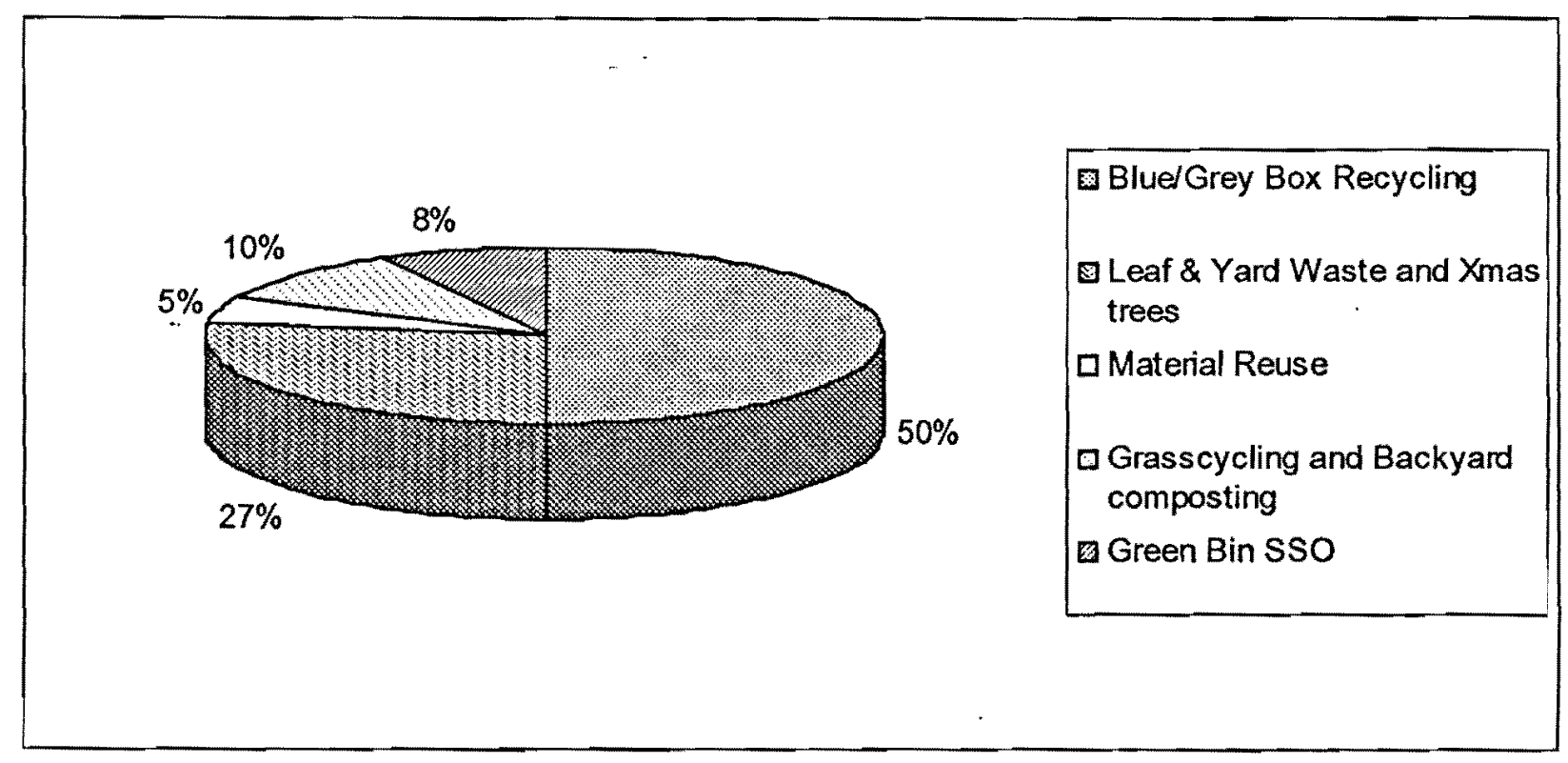

Figure 4.48 Composition of Diverted Waste in 2003 


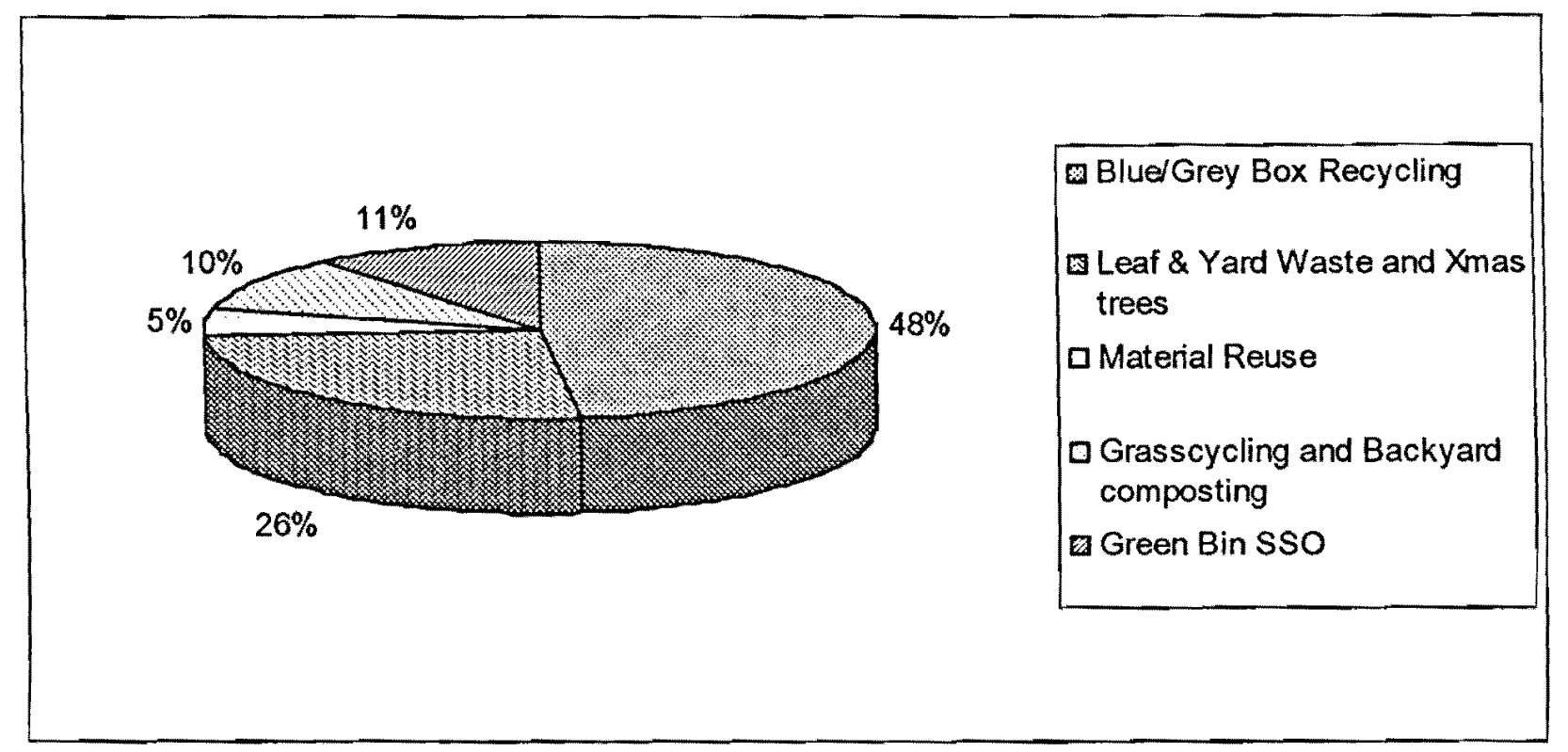

Figure 4.49 Composition of Diverted Waste in 2004

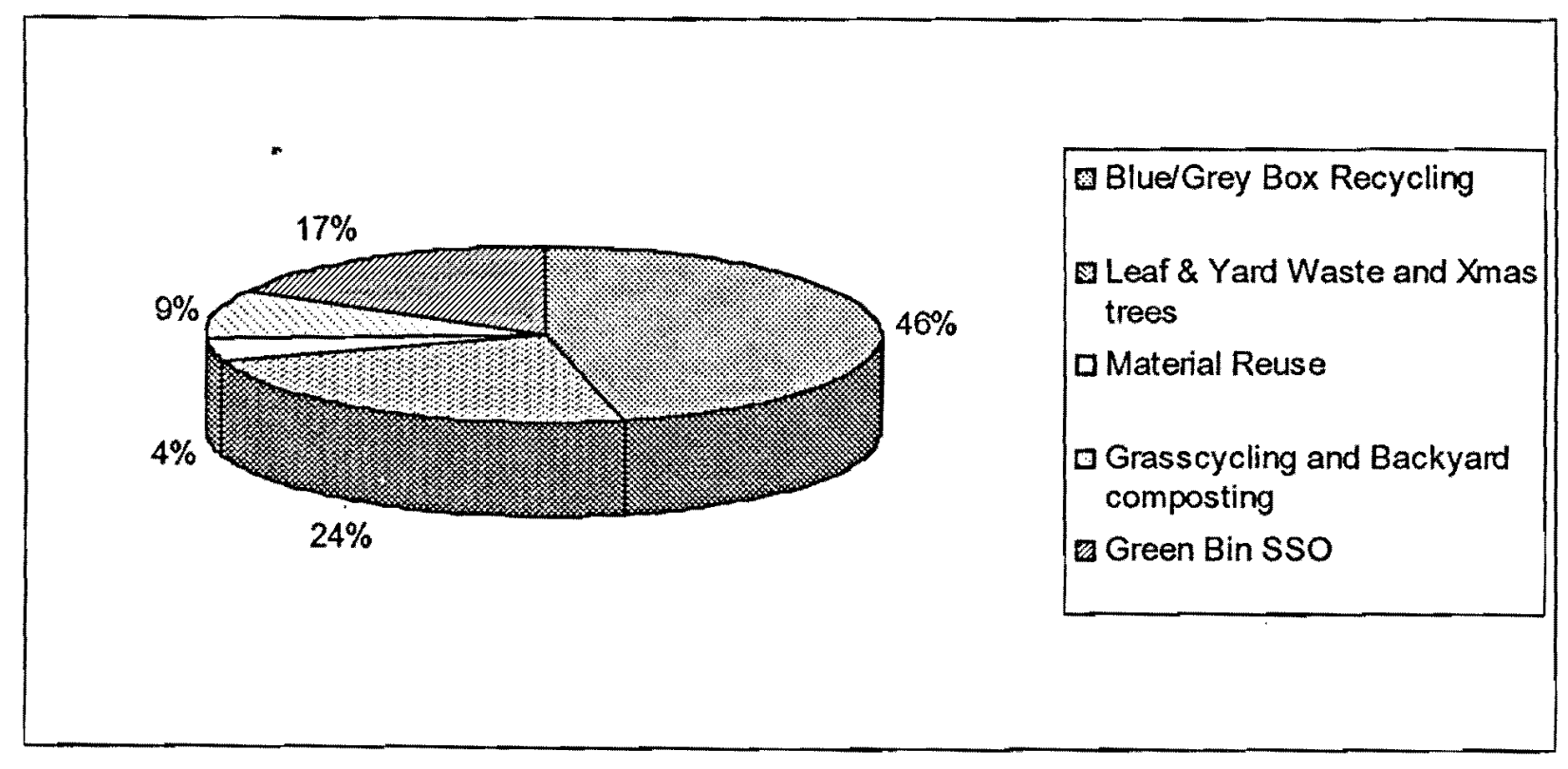

Figure 4.50 Composition of Diverted Waste in 2005 


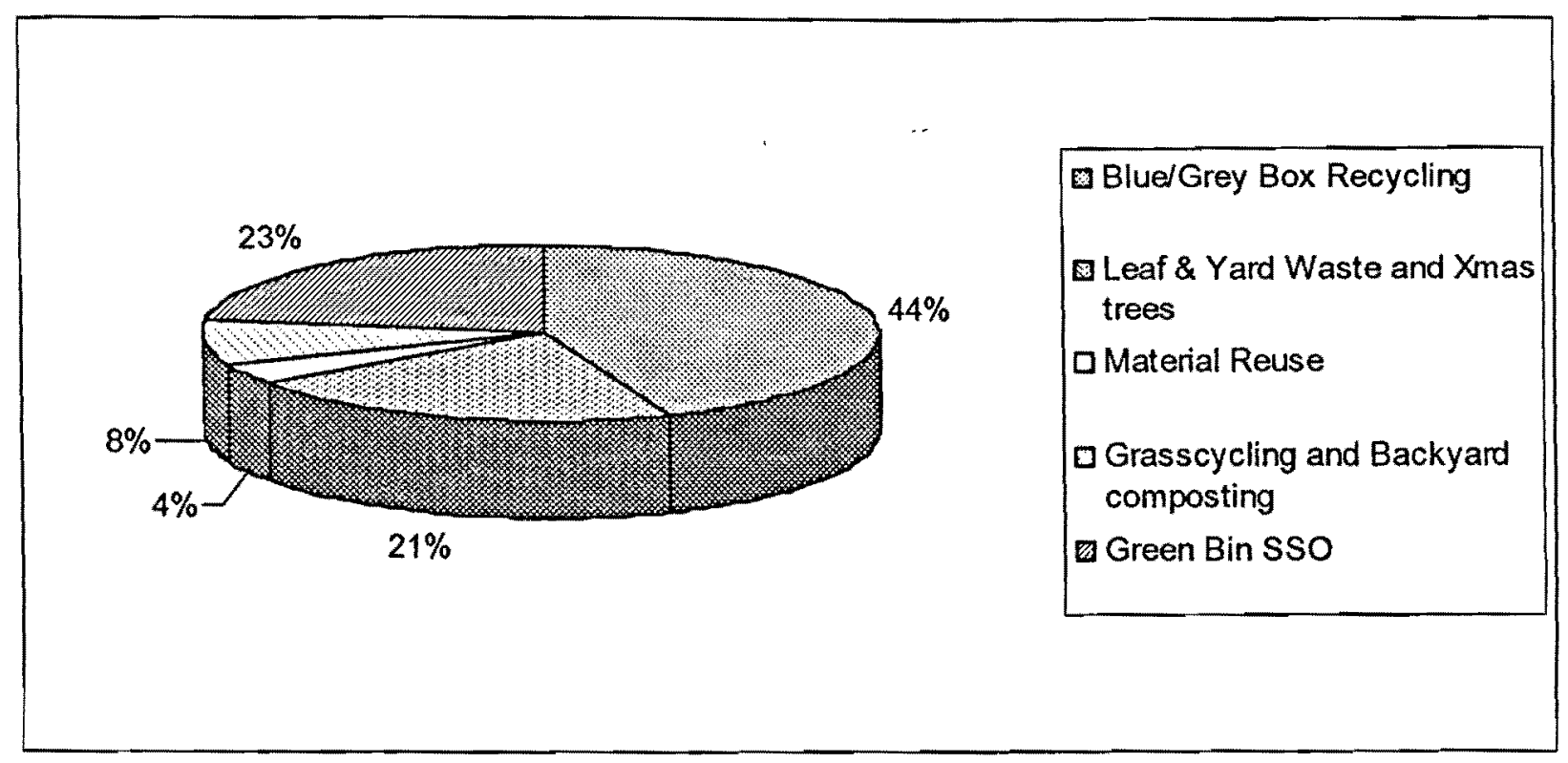

Figure 4.51 Composition of Diverted Waste in 2006

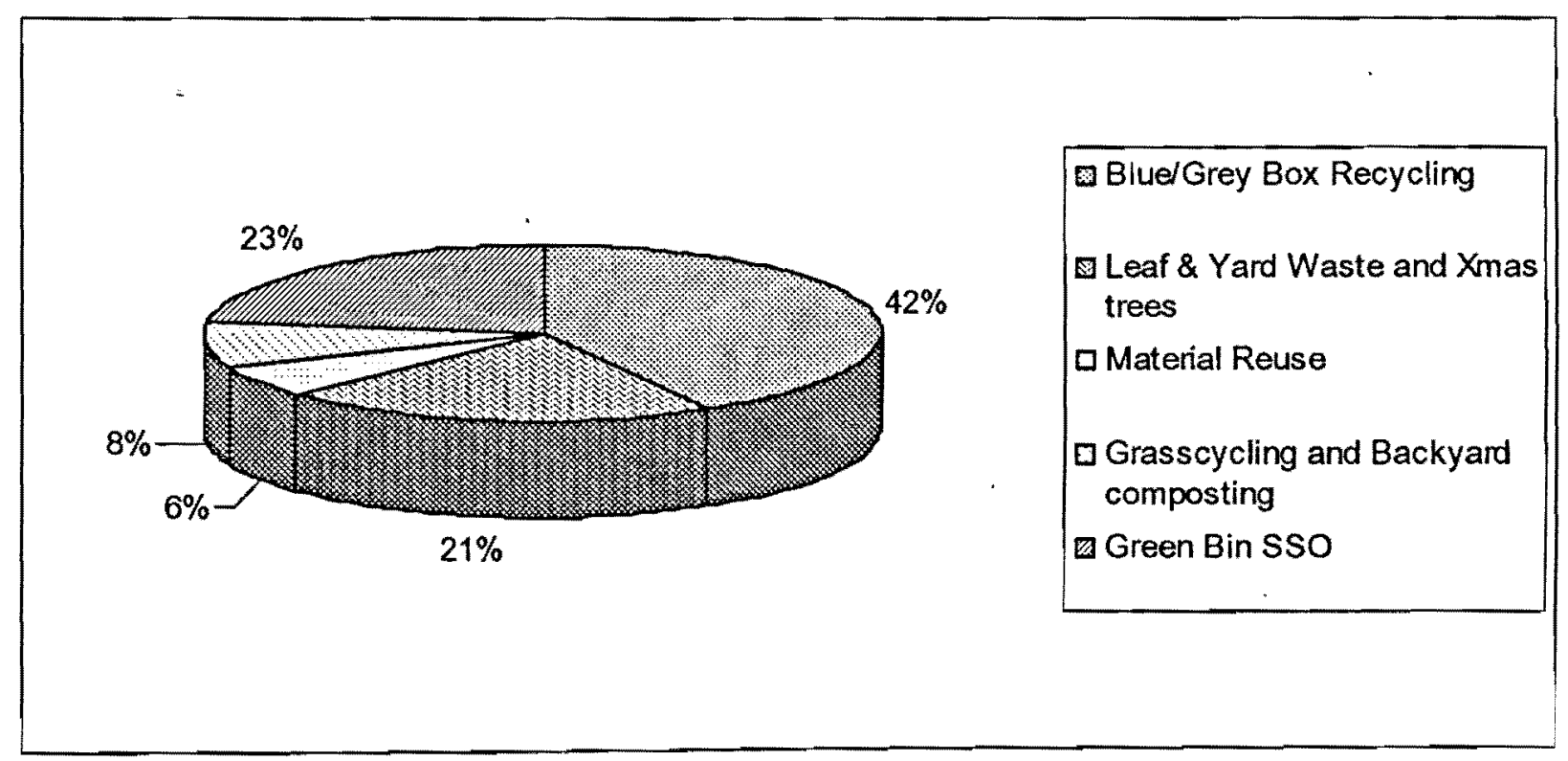

Figure 4.52 Composition of Diverted Waste in 2007 


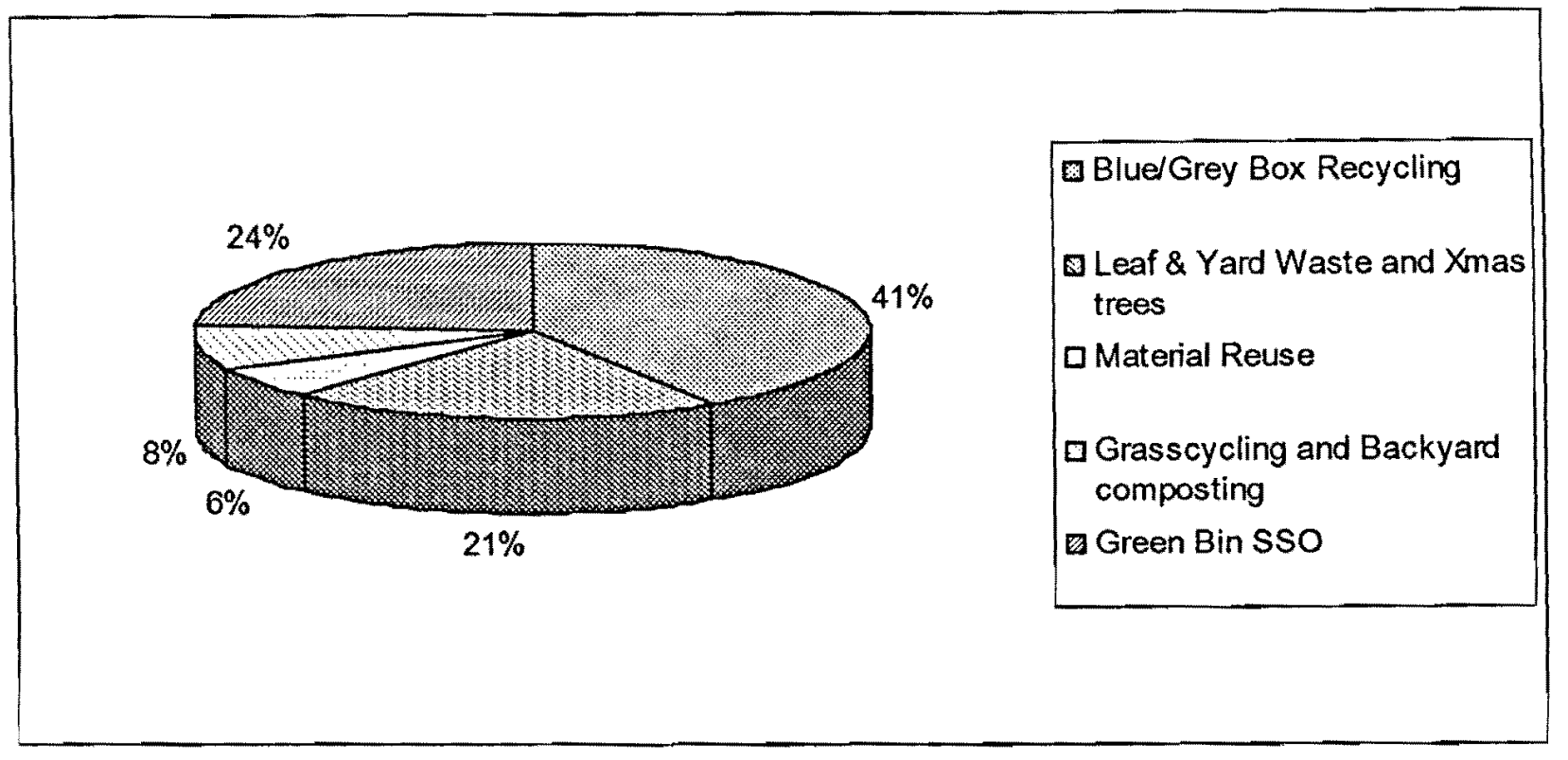

Figure 4.53 Composition of Diverted Waste in 2008

\subsubsection{Population and Waste Generation}

Population of the City of Toronto was 2,620,160 in 2002 and increased gradually through 2003 and 2004 to 2,698400 in 2005. Population decreased to $2,631,725$ in 2006 and increased to 2,730100 in 2007 and further increased to 2,738600 in 2008 . Waste generation grew from 886,802 tonnes in 2002 to 908,157 tonnes in 2003 . Waste generation decreased to 876,068 tonnes in 2004 and further decreased to 874,028 tonnes in 2005 with an increase to 885,024 tonnes in 2006. Waste generation decreased again to 865,100 tonnes in 2007 and increased again to 882,727 tonnes in 2008 . The trends of population growth and waste generation are shown in Figure 4.54. Population growth increased by $4.5 \%$ from 2002 to 2008 but waste generation decreased by $0.5 \%$ during this period. 


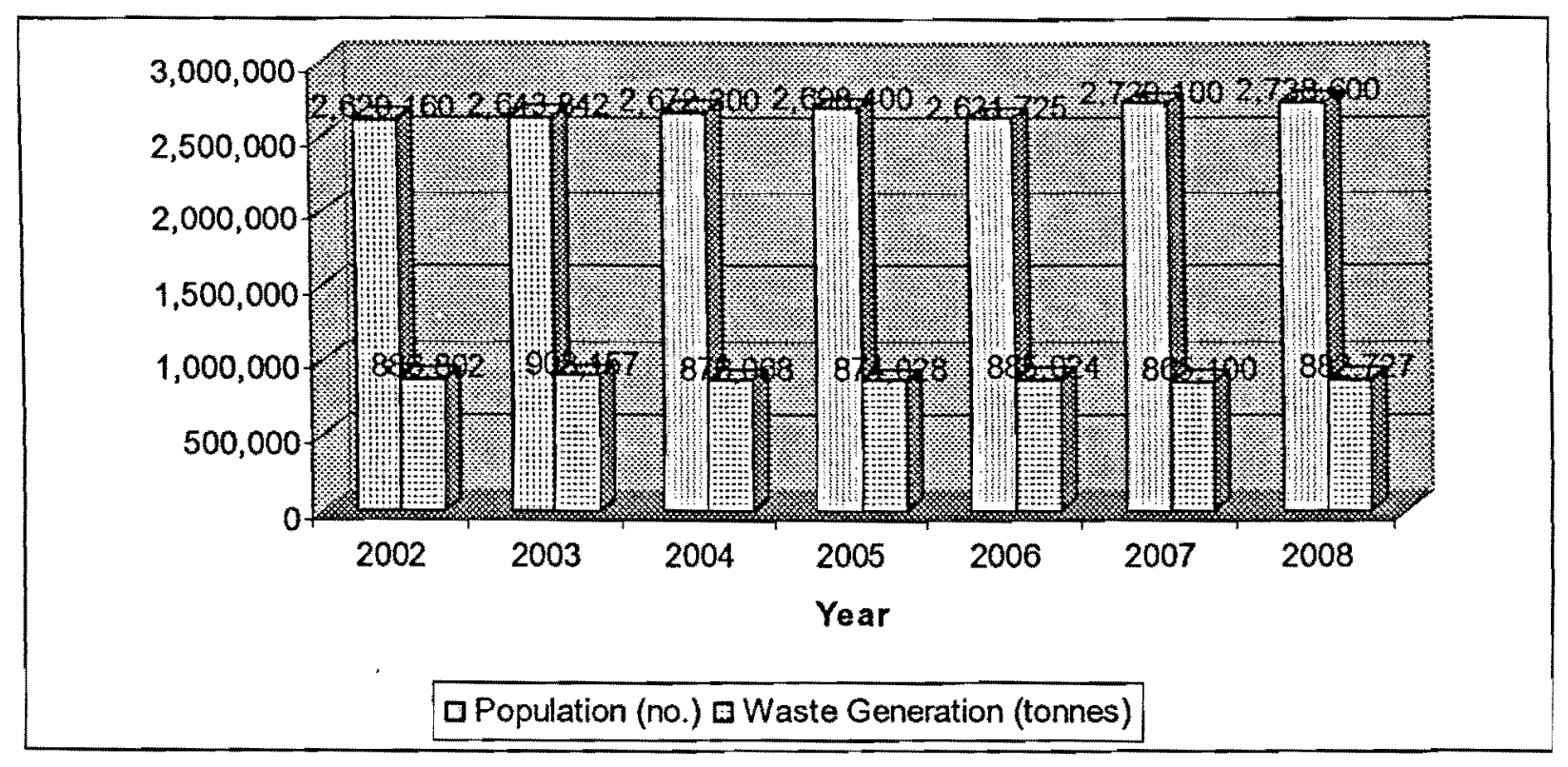

Figure 4.54 Population Growths and Waste Generation

\subsubsection{Waste Generations Per Capita}

In the City of Toronto waste generation per capita was $338 \mathrm{Kg}$ in 2002 and increased to $343 \mathrm{Kg}$ in 2003 . Waste generation per capita decreased to $328 \mathrm{Kg}$ in 2004 and further decreased to 324 $\mathrm{Kg}$ in 2005 . Waste generation per capita increased again to $336 \mathrm{Kg}$ in 2006 . Waste generation per capita decreased again to $317 \mathrm{Kg}$ in 2007 and increased to $322 \mathrm{Kg}$ in 2008 . The trend of waste generation per capita is shown in Figure 4.55. The historical trend of per capita waste generation shows a significant reduction of $317 \mathrm{Kg}$ in 2007 from the highest value of $343 \mathrm{Kg}$ in 2003 during 2002-2008 and 4.7\% reduction from 2002 to 2008. 


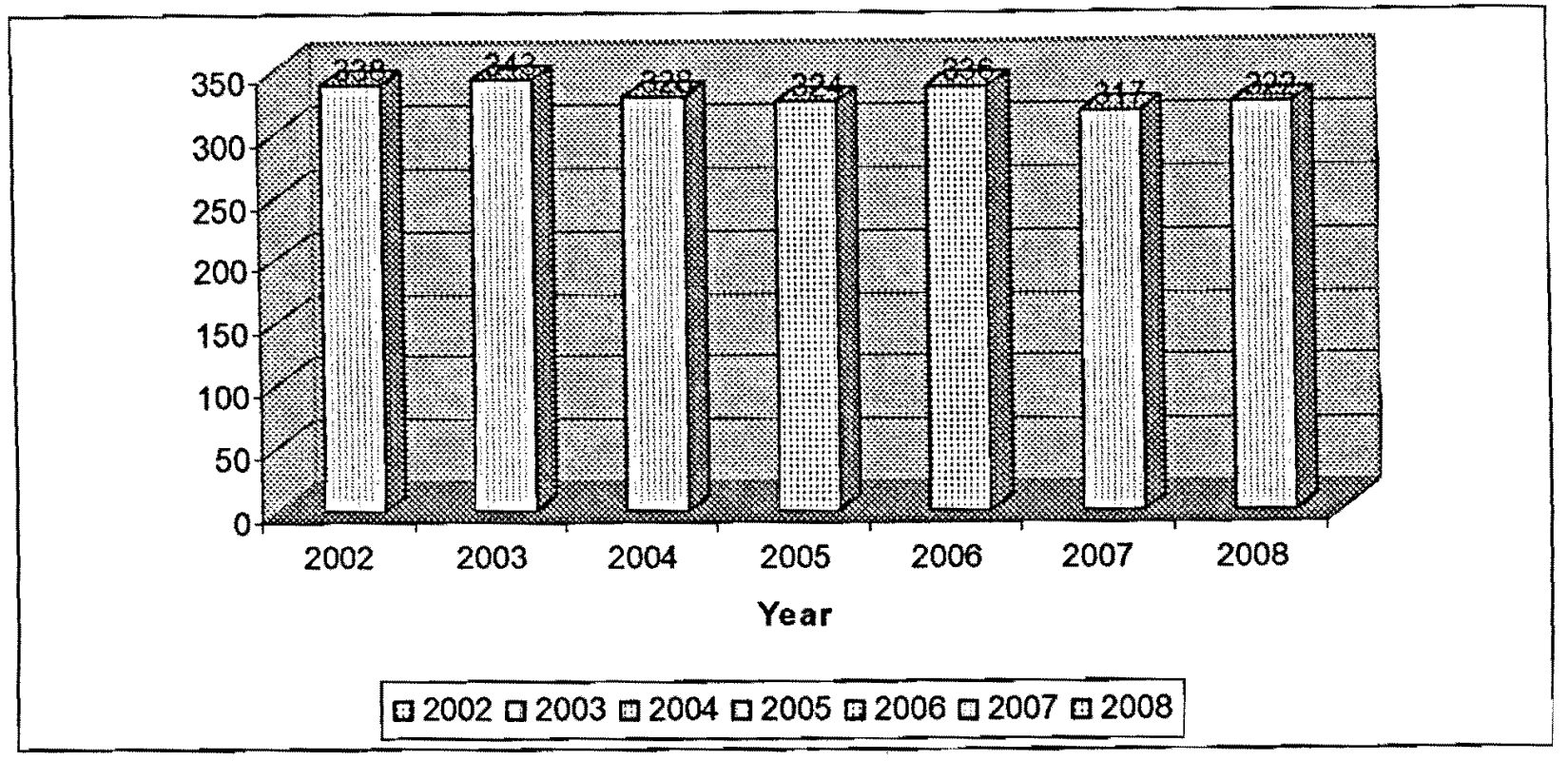

Figure 4.55 Waste Generations Per Capita

\subsection{Greater Toronto Area Waste Management}

\subsubsection{Waste Disposal (2002-2008)}

A comparative waste disposal trend from 2002-2008 for the Regional Municipalities of Durham, Halton, Peel, York and the City of Toronto and the Greater Toronto Area is shown in Figure 4.56. It is evident from the figure that the Regional Municipality of York performed much better than the others. Disposal from the Regional Municipality of York decreased from 210,486 tonnes in 2002 to 123,273 tonnes in 2008 , i.e. a decrease of $41.4 \%$ with slight rise in the years 2003 , 2004 and 2005. Disposal from the City of Toronto decreased gradually from 639,443 tonnes in 2002 to 494,539 tonnes in 2008 i.e. a decrease of $22.7 \%$. Disposal from the Regional Municipality of Peel increased from 220,312 tonnes in the year 2002 to 240,003 tonnes in 2008, i.e. an increase of $0.09 \%$ with a drop to 224,521 tonnes in 2007 . Disposal from the Regional Municipality of Durham decreased from 145,752 tonnes in 2002 to 116,464 tonnes in 2008 i.e. a decrease of $20 \%$ with slight rises in the years 2004 and 2005. Disposal from the Regional Municipality of Halton increased gradually from 101930 tonnes in 2002 to 120,421 tonnes in 
2006 i.e. an increase of $18 \%$ but finally decreased to 92,775 tonnes in 2008 i.e. a decrease of $8.9 \%$. Disposal from the GTA as a whole shows a decrease from $1,317,923$ tonnes in 2002 to 1,067054 tonnes in 2008 i.e.a decrease of $19 \%$ with a slight rise in 2003.

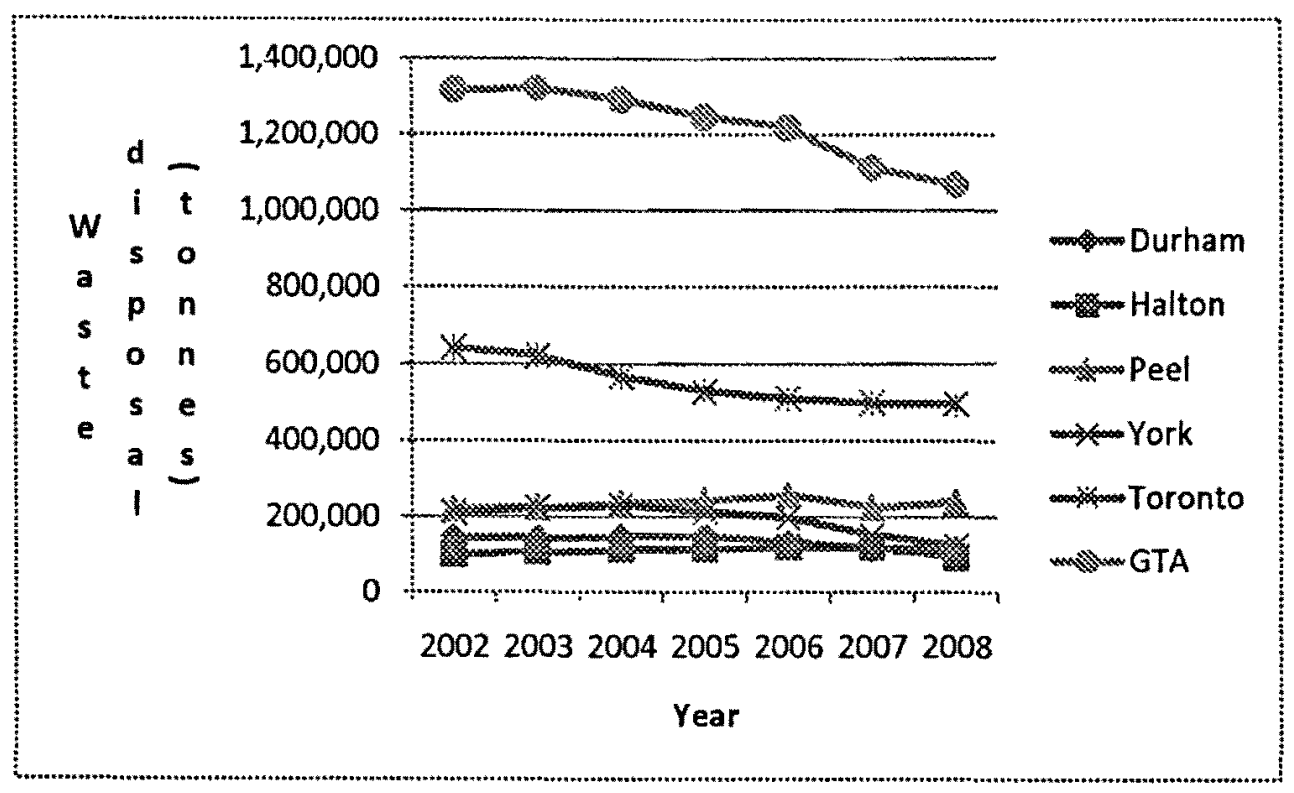

Figure 4.56 Waste Disposal in the GTA

\subsubsection{Waste Diversion in Tonnes (2002-2008)}

A comparative quantitative waste diversion trend from 2002-2008 for the Regional Municipalities of Durham, Halton, Peel, York and the City of Toronto and the Greater Toronto Area is shown in Figure 4.57. It is evident from the figure that the Regional Municipality of York performed much better than the others. Diversion from the Regional Municipality of York increased gradually from 65,601 tonnes in 2002 to 207,456 tonnes in 2008, i.e. an increase of $216.2 \%$. Diversion from the City of Toronto increased gradually from 247,359 tonnes in 2002 to 388,188 tonnes in 2008 i.e. an increase of $56.9 \%$ with a slight drop in 2007 . Diversion from the Regional Municipality of Peel increased gradually from 178,020 tonnes in the year 2002 to 242,290 tonnes in 2008 , i.e. an increase of $36 \%$. Diversion from the Regional Municipality of Durham increased gradually from 60,403 tonnes in 2002 to 119,126 tonnes in 2008 i.e. an increase of $97.2 \%$. Diversion from the Regional Municipality of Halton increased gradually from 
66,912 tonnes in 2002 to 121,201 tonnes in 2008 i.e. an increase of $81.1 \%$ with a slight decrease in 2007. Diversion from the GTA as a whole shows a gradual increase from 618,295 tonnes in 2002 to $1,078,261$ tonnes in 2008 i.e. an increase of $74.4 \%$.

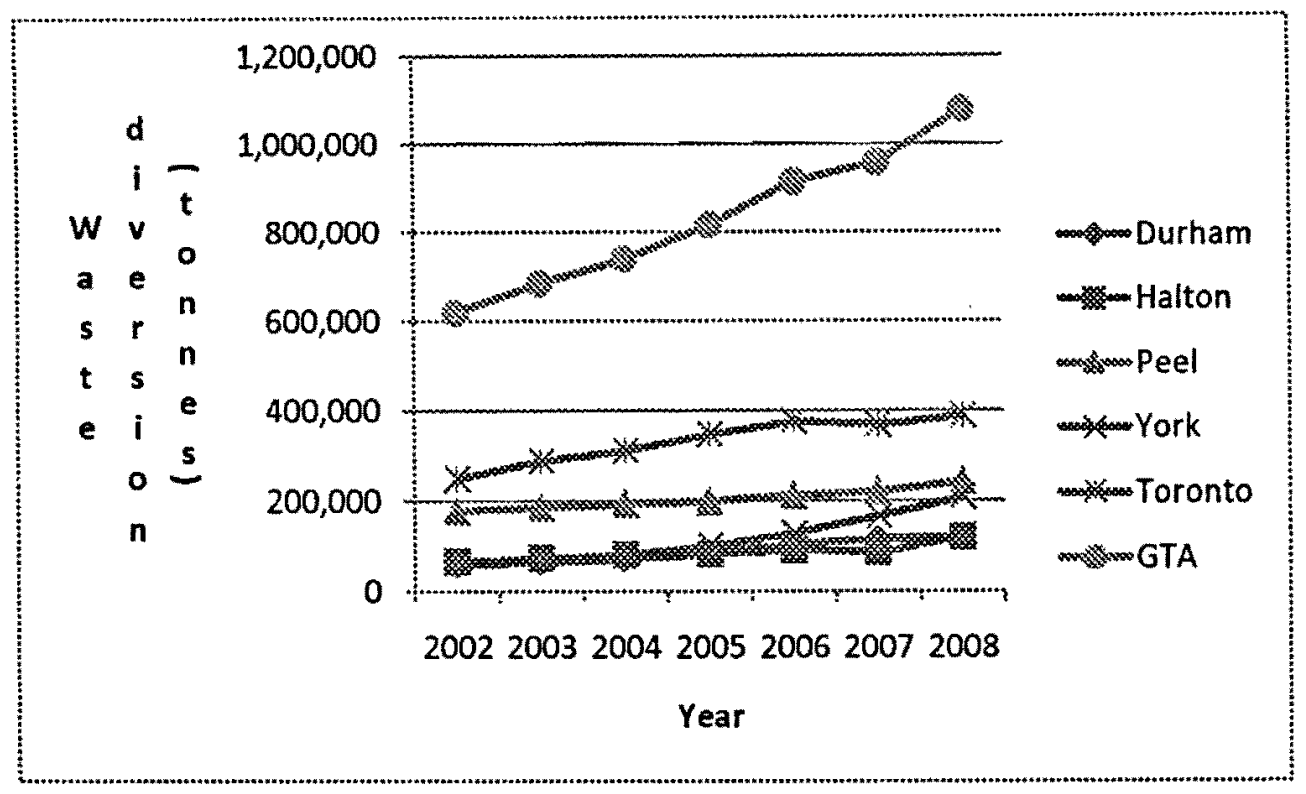

Figure 4.57 Waste Diversion (Tonnes) in the GTA

\subsubsection{Waste Diversion Percentage (2002-2008)}

A comparative waste diversion percentage trend from 2002-2008 for the Regional Municipalities of Durham, Halton, Peel, York and the City of Toronto and the Greater Toronto Area is shown in Figure 4.58. It is evident from the figure that the Regional Municipality of York performed much better than the others. Diversion from the Region of York increased gradually from $23.76 \%$ in 2002 to $62.73 \%$ in 2008 i.e. an increase of $39 \%$. Diversion from the Regional Municipality of Peel increased gradually from $44.7 \%$ in the year 2002 to $50.2 \%$ in 2008 , i.e. an increase of $5.5 \%$. Diversion from the City of Toronto increased gradually from $28 \% 2002$ to $44 \%$ in 2008, i.e. an increase of $16 \%$. Diversion from the Regional Municipality of Durham increased gradually from $29.3 \%$ in 2002 to $50.6 \%$ in 2008 i.e. an increase of $21.3 \%$. Diversion from the Regional Municipality of Halton increased gradually from $39.6 \% 2002$ to $56.6 \%$ in 2008 i.e. an increase of 
$17 \%$. Diversion from the GTA as a whole shows a gradual increase from $32 \%$ in 2002 to $50.2 \%$ in 2008 i.e. an increase of $18.2 \%$.

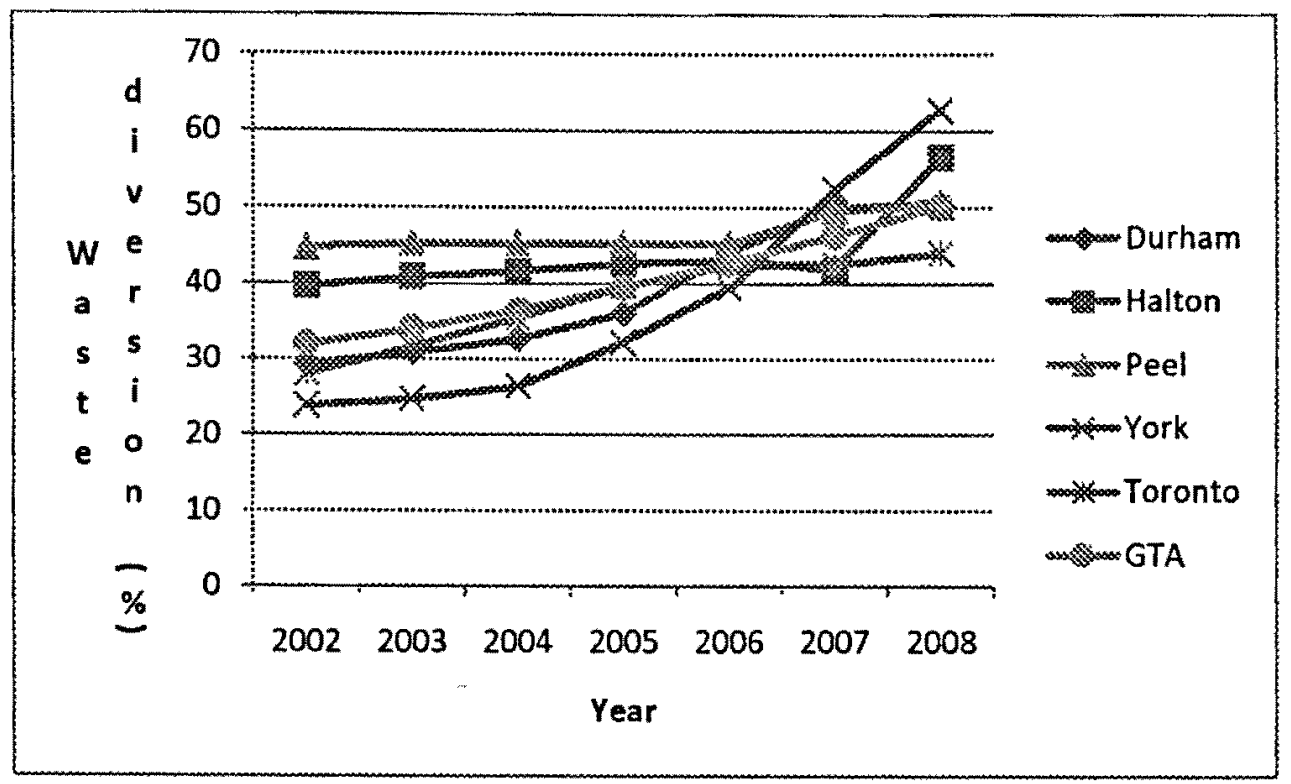

Figure 4.58 Waste Diversion (\%) in the GTA

\subsubsection{Total Waste Managed (2002-2008)}

A comparative representation of total quantity of waste managed during 2002-2008 by the Regional Municipalities of Durham, Halton, Peel, York and the City of Toronto and the Greater Toronto Area is shown in Figure 4.59. It is evident from the figure that the City of Toronto performed exceptionally well than the others. Total quantity of waste managed by the City of Toronto decreased from 886,802 tonnes in 2002 to 882,727 tonnes in 2008 i.e. a decrease of $0.005 \%$ with a slight rise in 2003 . Total quantity of waste managed by the Regional Municipality of Peel increased gradually from 398,332 tonnes in the year 2002 to 482,293 tonnes in 2008 , i.e. an increase of $21 \%$ with a slight drop in 2007 . Total quantity of waste managed by the Regional Municipality of York increased gradually from 276,087 tonnes in 2002 to 330,729 tonnes in 2008 , i.e. an increase of $19.8 \%$ with a slight drop in 2007 . Total quantity of waste managed by the Regional Municipality of Durham increased gradually from 206,155 tonnes in 2002 to 235,590 tonnes in 2008 i.e. an increase of $14.3 \%$ with a slight drop in 2007 . Total quantity of 
waste managed by the Regional Municipality of Halton increased gradually from 168,842 tonnes in 2002 to 213,976 tonnes in 2008 i.e. an increase of $26.7 \%$ with a slight decrease in 2007 . Total quantity of waste managed by the GTA as a whole shows a gradual increase from 1,936218 tonnes in 2002 to $2,145,315$ tonnes in 2008 i.e. an increase of $10.8 \%$ with a slight decrease in 2007.

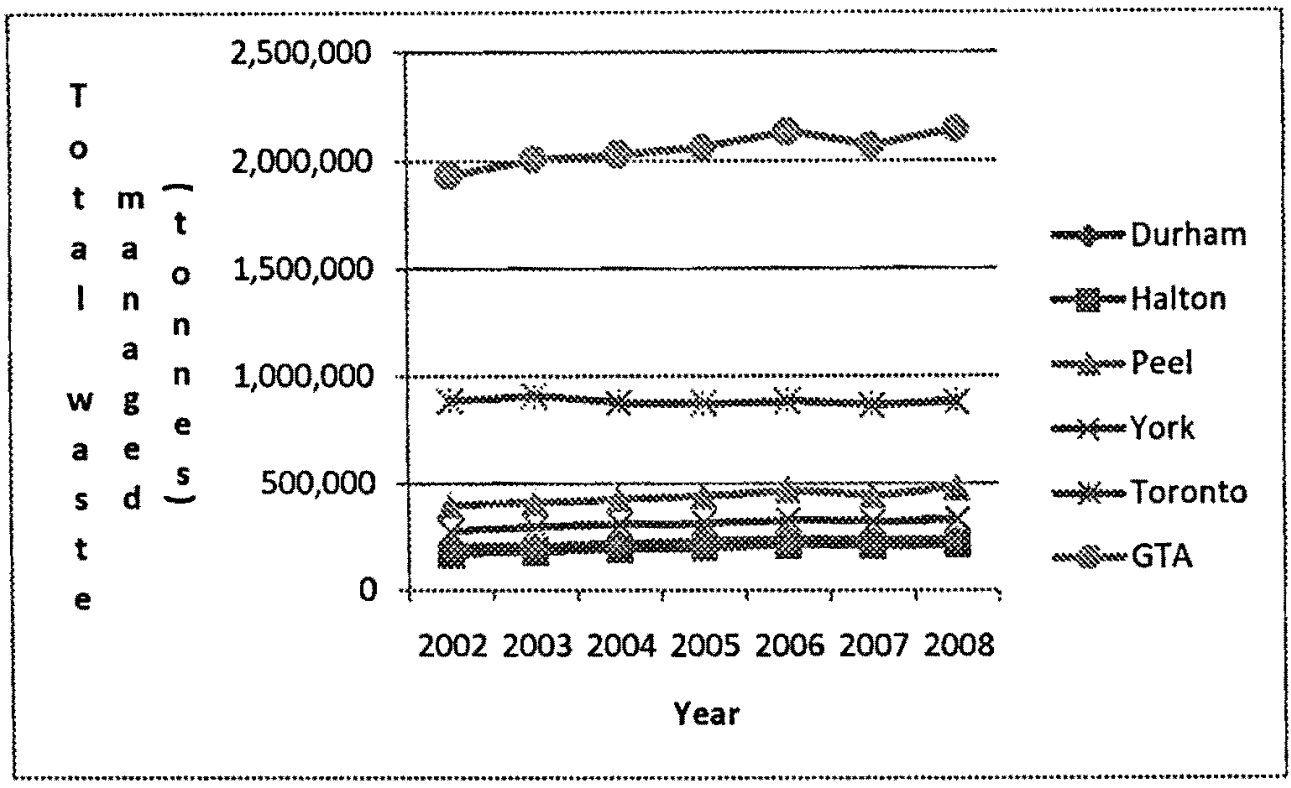

- Figure 4.59 Total Waste Managed in the GTA

\subsubsection{Population Growth (2002-2008)}

A comparative population growth trend from 2002-2008 for the Regional Municipalities of Durham, Halton, Peel, York and the City of Toronto and the Greater Toronto Area is shown in Figure 4.60. Population growth of the City of Toronto increased gradually from $2,620,160$ No. in 2002 to 2,738600 No. in 2008 i.e. an increase of $4.5 \%$ with a slight decrease in 2006. Population growth of the Regional Municipality of Peel increased gradually from 1,024,000 No. in the year 2002 to $1,200,000$ No. in 2008 , i.e. an increase of $17.2 \%$. Population growth of the Regional Municipality of York increased gradually from 798,798 No. in 2002 to 1,011,360 No. in 2008, i.e. an increase of $26.6 \%$. Population growth of the Regional Municipality of Durham increased gradually from 536,575 No. in 2002 to 605,730 No. in 2008 i.e. an increase of $12.9 \%$. Population 
growth of the Regional Municipality of Halton increased gradually from 386,900 No. in 2002 to 466,930 No. in 2008 i.e. an increase of $20.7 \%$. Population growth of the GTA as a whole shows a gradual increase from 5,366,433 No. in 2002 to $6,022,620$ No. in 2008 i.e. an increase of $12.2 \%$.

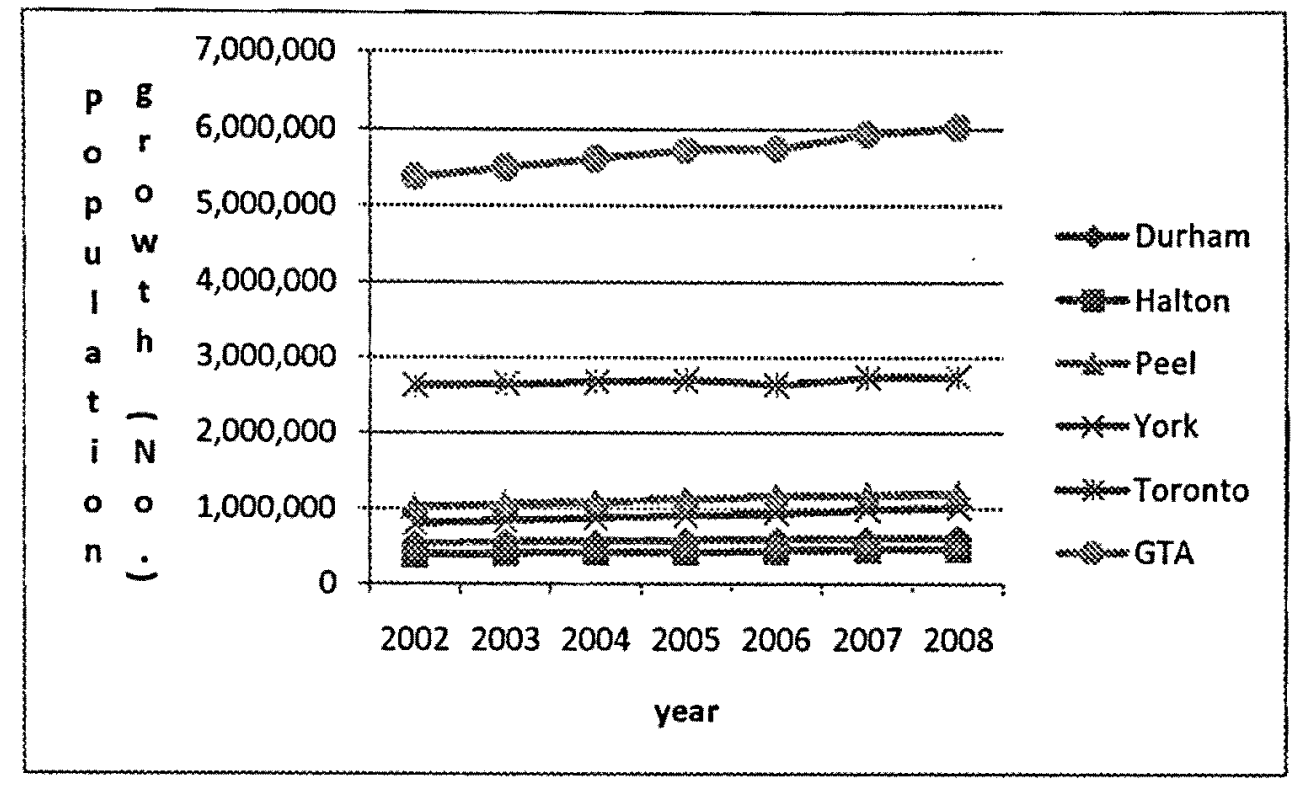

Figure 4.60 Population Growths in the GTA

\subsubsection{Waste Generations Per Capita (2002-2008)}

A comparative per capita waste generation trend from 2002-2008 for the Regional Municipalities of Durham, Halton, Peel, York and the City of Toronto and the Greater Toronto Area is shown in Figure 4.61. It is evident from the figure that the City of Toronto and the Regional Municipality of York performed much better than the others. Per capita waste generation of the City of Toronto decreased gradually from $338 \mathrm{Kg}$ in 2002 to $322 \mathrm{Kg}$ in 2008 i.e. a decrease of $4.7 \%$ with slight fluctuations in between. Per capita waste generation of the Regional Municipality of York increased from $346 \mathrm{~kg}$ in 2002 to up to $350 \mathrm{Kg}$ in 2006 with final achievement of $327 \mathrm{Kg}$ in 2008 , i.e. a decrease of $5.5 \%$ between 2002 and 2008 . Per capita waste generation of the Regional Municipality of Peel increased from $389 \mathrm{Kg}$ in the year 2002 to $402 \mathrm{~kg}$ in 2008, i.e. an increase of $3.3 \%$ with slight fluctuations in between. Per capita waste generation of the Regional 
Municipality of Durham increased from $384 \mathrm{~kg}$ in 2002 to up to $405 \mathrm{Kg}$ in 2005 with a little drop in 2003 and with a final achievement of $389 \mathrm{Kg}$ in 2008 i.e. an increase of $1.3 \%$ between 2002 and 2008. Per capita waste generation of the Regional Municipality of Halton increased from $434 \mathrm{Kg}$ in 2002 to $482 \mathrm{Kg}$ in 2006 with a little drop in 2005 and with a final achievement of 458 $\mathrm{Kg}$ in 2008 i.e. an increase of $5.5 \%$ between 2002 and 2008. Per capita waste generation of the GTA as a whole shows a decrease from $361 \mathrm{Kg}$ in 2002 to $356 \mathrm{Kg}$ in 2008 i.e. a decrease of $1.4 \%$ with fluctuations in between and the highest rise of $371 \mathrm{Kg}$ in 2006 .

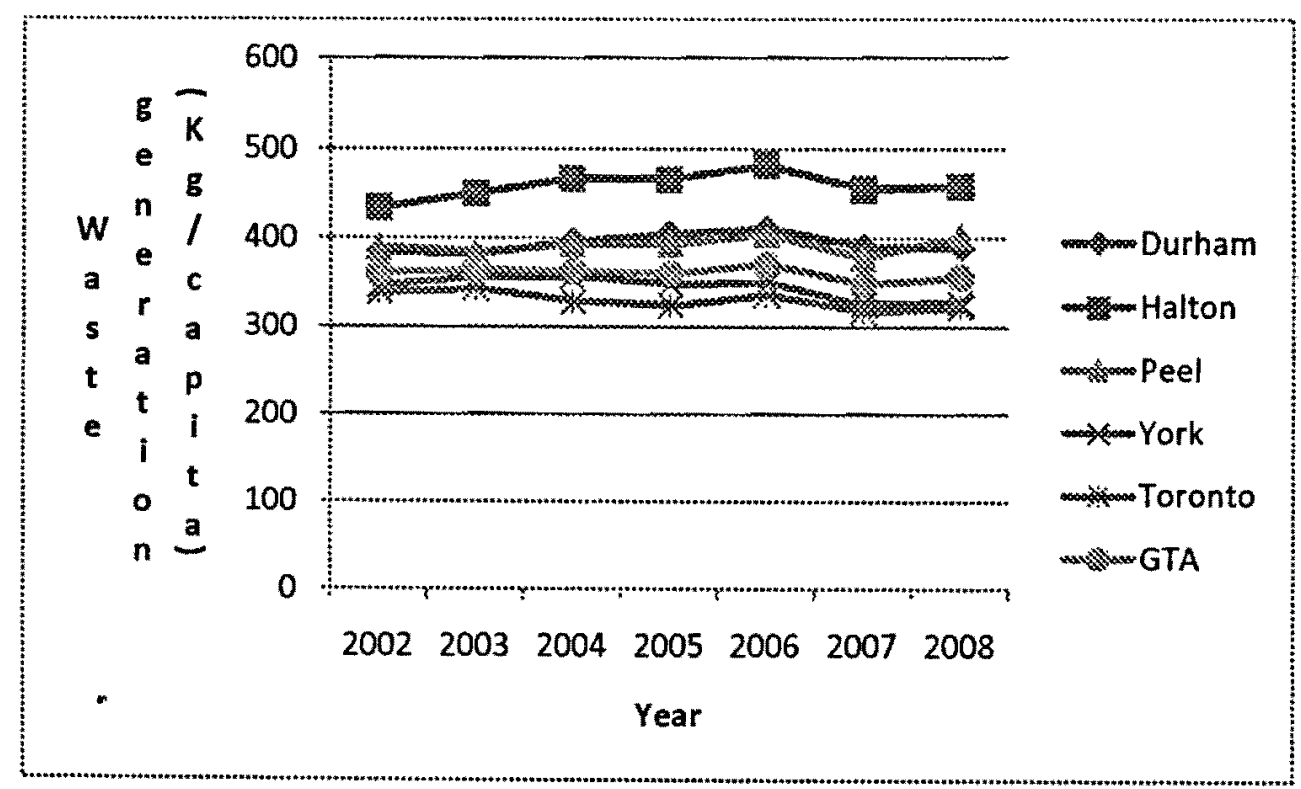

Figure 4.61 Waste Generations Per Capita in the GTA 


\subsubsection{Main Findings of Comparison Study}

The Regional Municipality of York ranked $1^{\text {st }}$ among all the Regional Municipalities and the City of Toronto in waste disposal for an achievement of the highest reduction of $41.4 \%$ during the study period. On the contrary, the Regional Municipality of Peel ranked $5^{\text {th }}$ and performed the worst with an achievement of $0.09 \%$ increase during the same period.

The Regional Municipality of York ranked $1^{\text {st }}$ in the GTA in waste diversion tonnage with an achievement of the highest increase of $216.2 \%$ during the study period and the Regional Municipality of Peel ranked $5^{\text {th }}$ with an achievement of $36 \%$ increase during the same period. Similar ranking was achieved by both the Regions in waste diversion percentage increases.

The City of Toronto ranked $1^{\text {st }}$ in the GTA in total waste managed with an exceptional achievement of a decrease of $0.005 \%$ during the study period while all the Regional Municipalities achieved increases and the Regional Municipality of Halton ranked $5^{\text {th }}$ with an achievement of $26.7 \%$ increase during the same period.

The Regional Municipality of York ranked $1^{\text {st }}$ among all the Regional Municipalities and the City of Toronto in waste generation per capita for an achievement of the highest reduction of $5.5 \%$ during the study period and the Regional Municipality of Halton ranked $5^{\text {th }}$ with an achievement of $5.5 \%$ increase during the same period. Again, the City of Toronto ranked $1^{\text {st }}$ in the GTA with the lowest waste generation of $322 \mathrm{Kg}$ per capita and the Regional Municipality of Halton ranked $5^{\text {th }}$ with the highest performance of $458 \mathrm{Kg}$ per capita in the year 2008 .

\subsubsection{Cost Analysis for Solid Waste Management}

\section{A. Cost of Waste Collection Per Tonne in 2007}

Cost of solid waste collection per tonne for the Regional Municipality of Durham was $\$ 92$, for the Regional Municipality of Halton was $\$ 79$, for the Regional Municipality of Peel was $\$ 71$, and for the City of Toronto was $\$ 83$ in 2007 as shown in the Figure 4.62. Cost of collection was 
the highest for the Regional Municipality of Durham and the lowest for the Regional Municipality of Peel. Cost variation was due to different collection methods followed by different Regional Municipalities and the City of Toronto.

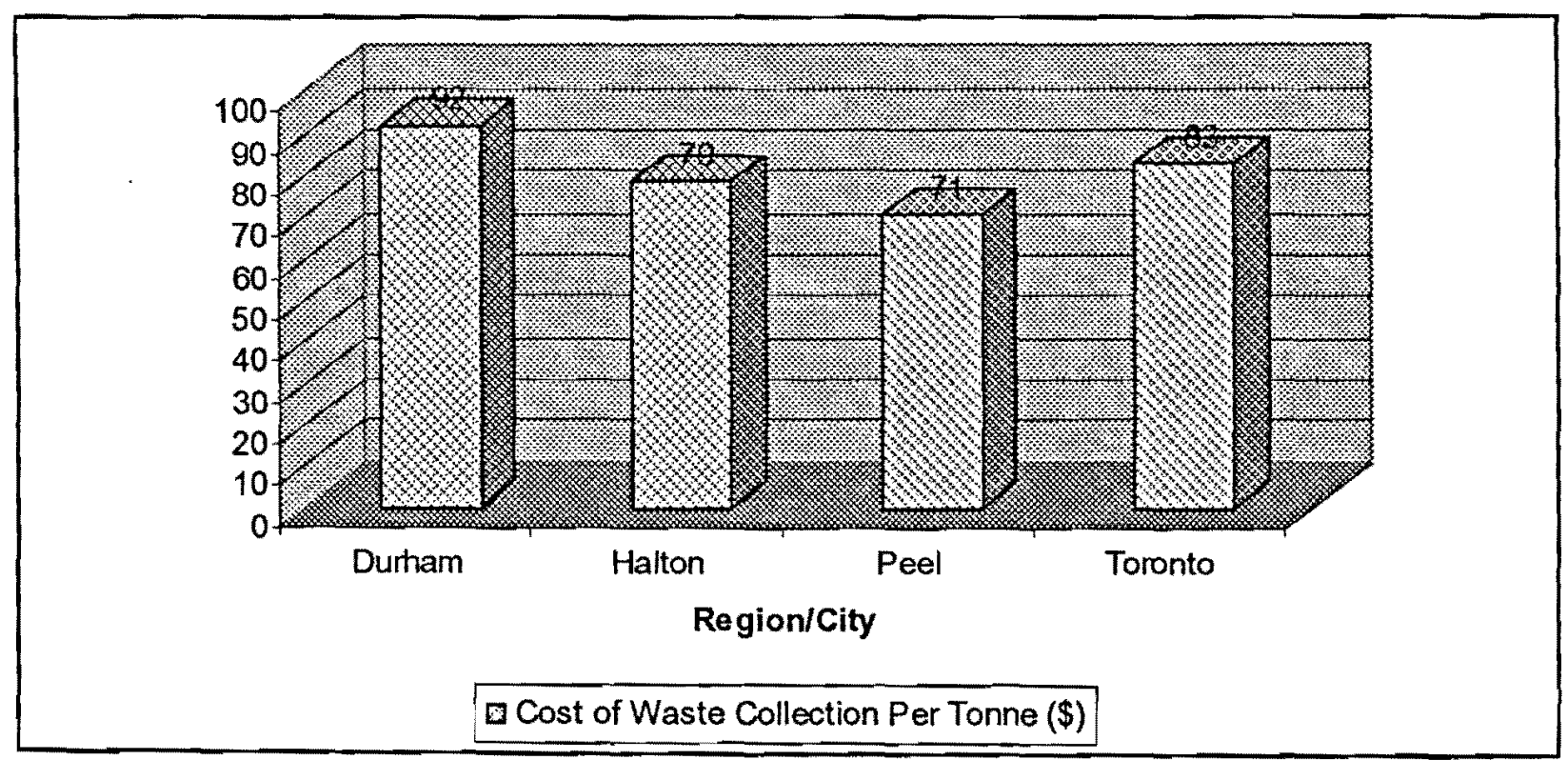

Figure 4.62 Cost of Solid Waste Collection Per Tonne

\section{B. Cost of Waste Diversion Per Tonne in 2007}

Cost of solid waste diversion per tonne for the Regional Municipality of Durham was $\$ 134$, for the Regional Municipality of Halton was $\$ 128$, for the Regional Municipality of Peel was $\$ 138$, for the Regional Municipality of York was $\$ 65$ and for the City of Toronto was $\$ 202$ in 2007 as shown in the Figure 4.63. Cost of diversion was the highest for the City of Toronto and the lowest for the Regional Municipality of York. Cost variation was due to different diversion methods/programs followed by different Regional Municipalities and the City of Toronto. 


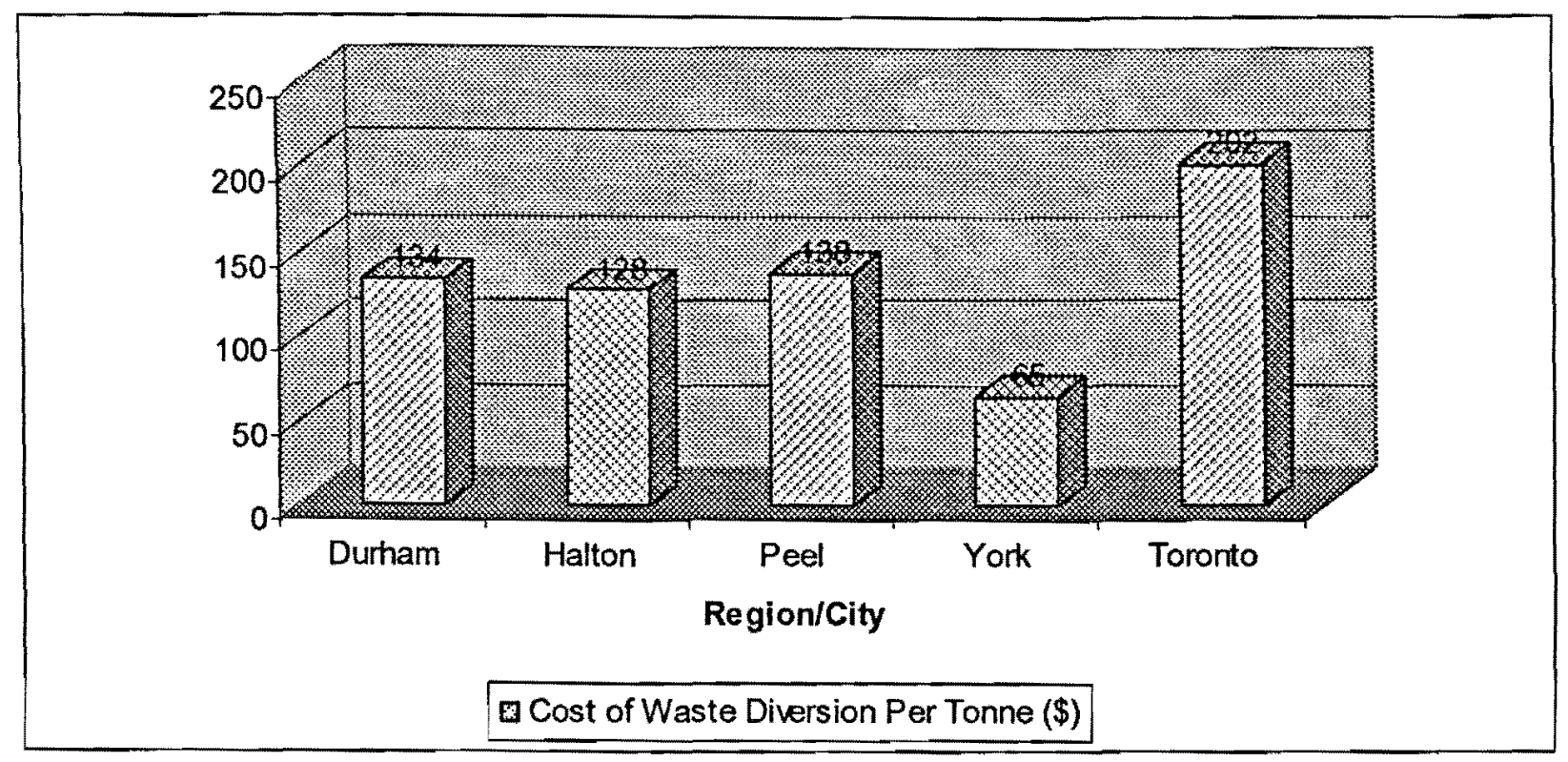

Figure 4.63 Cost of Solid Waste Diversion Per Tonne

\section{Cost of Waste Disposal Per Tonne in 2007}

Cost of solid waste disposal per tonne for the Regional Municipality of Durham was $\$ 113$, for the Regional Municipality of Halton was $\$ 45$, for the Regional Municipality of Peel was $\$ 135$, for the Regional Municipality of York was $\$ 88$ and for the City of Toronto was $\$ 110$ in 2007 as shown in the Figure 4.64. Cost of disposal was the highest for the Regional Municipality of Peel and the lowest for the Regional Municipality of Halton. About 50\% waste export to Michigan and about $38 \%$ sending to waste to energy facility (incinerator) caused the highest cost of disposal for the Region of Peel. The use of Halton's landfill site for waste disposal by the Regional Municipality of Halton helped achieve the lowest cost for disposal. Cost variation was due to different disposal methods followed by different Regional Municipalities and the City of Toronto. 


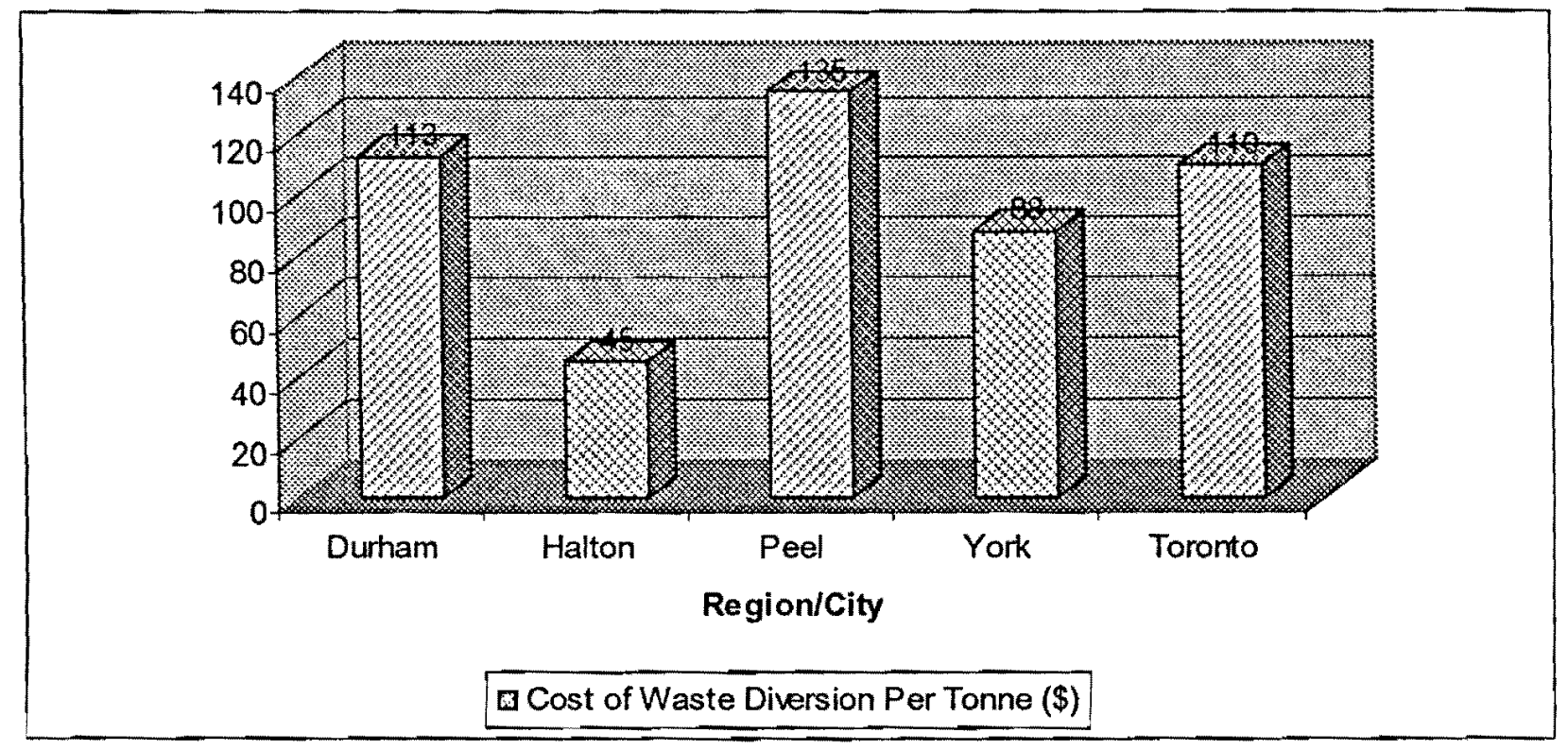

Figure 4.64 Cost of Solid Waste Disposal Per Tonne 


\section{CHAPTER 5}

\section{WASTE MANAGEMENT. IN THE GTA}

\subsection{General}

In $2006,27,249,178$ tonnes of waste material was disposed of by Canada and 10,437,780 tonnes of waste material was disposed of by the Province of Ontario and again 1,218,540 tonnes of residential waste material was disposed of by the Greater Toronto Area (GTA). So, 38.3\% of Canadian waste was disposed of by the Province of Ontario alone and again $11.7 \%$ of provincial waste was disposed of by the GTA residential waste alone. In 2006, 7,749,030 tonnes of waste material was diverted by Canada and 2,396,856 tonnes of waste material was diverted by the Province of Ontario and again 913,930 tonnes of residential waste material was diverted by the GTA. So, $31 \%$ of Canadian waste was diverted by the Province of Ontario alone and again $38 \%$ of provincial waste was diverted by the GTA residential waste alone. In 2008, 1,067,054 tonnes of residential waste material was disposed of by the GTA and 1,078,261 tonnes of residential waste material was diverted by the GTA. In comparison to the year 2006, GTA disposal of waste material was decreased by $12.43 \%$ and diversion of waste material was increased by $18 \%$ in the year 2008. In 2006, diversion rate for Canada was $22 \%$ and that for the Province of Ontario was $18.7 \%$. But GTA diversion rate of residential waste was $44 \%$ in 2006 which increased to $50 \%$ in 2008. All the four Regional Municipalities in the GTA achieved diversion rates of $50 \%$ and above in the year 2008. But the City of Toronto achieved a diversion rate of $44 \%$ in 2008 . Only the Regional Municipality of York achieved a diversion rate of $63 \%$ exceeding the Provincial diversion goal of $60 \%$ by 2008 . Waste generation per capita was $1107 \mathrm{~kg}$ for Canada and 1055 $\mathrm{kg}$ for Ontario in 2006. In the same year, residential waste generation per capita for the GTA was $371 \mathrm{~kg}$ and decreased to $356 \mathrm{~kg}$ in 2008. This indicated a reduction of per capita waste generation by $2.7 \%$ in the GTA in 2008 compared to 2006 . In the year 2002, per capita residential waste generation in the GTA was $361 \mathrm{Kg}$. This is another indication of per capita waste generation reduction by $1.4 \%$ in the GTA in 2008 compared to 2002 . The diversion rates for the three Regions and the City of Toronto were behind the Provincial diversion goal of $60 \%$ by 2008 . In order to achieve effective waste management, a comprehensive waste management 
approach comprising of reduction of waste generation, increment of the rates of recycling and reuse, and reduction of disposal to the landfills, the diversion goal of $60 \%$ was proposed by the Provincial Government. In addition to the Provincial diversion goal, each Regional Municipality and the City of Toronto have got their own diversion goals and have adopted integrated waste management approach.

\subsection{Integrated Waste Management in the GTA}

Integrated waste management system in place consists of the following waste management options:

1) Source reduction

2) Recycling and Reuse

3) Green Bin SSO

4) Biological Treatment

5) Incineration *

6) Landfilling

\subsubsection{Source Reduction}

Source reduction is the first and the most effective step towards waste minimisation. It helps reduce the volume and toxicity of the generated waste and thereby reduce GHG emissions. It also helps in cost savings from transportation and extends the life of landfills. Source reduction refers to changes in design, manufacture, purchase or use of materials or products (including packaging) to reduce their contribution to the municipal solid waste (MSW) stream (EPA 2002d). The widely used practice across the GTA of leaving grass clippings on the lawn and never collecting it back is an example of source reduction program. Introduction of five cent per 
plastic shopping bag that encourages people using cotton or other disposable bag is another example of source reduction initiative.

Consumers can play an important role in source reduction. They can buy less consumable and use them most efficiently. They can modify their choice of purchasing durable products avoiding or reducing the disposable ones. This may help private sectors modify their production strategy. Manufacturers can redesign their manufacturing processes with a view to producing effective and long lasting products and finally with the aim of generating minimum waste through the whole process.

Weight of 2 litre soft drink plastic bottles were reduced by $28 \%$ (from $68 \mathrm{gm}$ to $51 \mathrm{gm}$ ) by the US which saved 250 million lbs (113000 tonnes) of plastic materials annually and prevented from entering in to the waste stream since 1977 (EPA 2002d).

Green Dot program, an extended producer responsibility program (EPR) was found to be highly responsive in Germany. This program helped reduce packaging requirement from $13 \mathrm{Mt}$ in 1991 to $11.5 \mathrm{Mt}$ in 1997 (Schiffler 2002).

National Packaging Protocol was endorsed by the Canadian Council of Ministers of the Environment (CCME) in 1990. They set three milestone targets for the reduction of packaging disposal from estimated 1988 levels: $20 \%$ by $1992 ; 35 \%$ by 1996 , and; $50 \%$ by the year 2000 . 1996 monitoring results showed a $51.2 \%$ reduction by weight of packaging materials compared to the 1988 baseline estimates which exceeded both the National Packaging Protocol's milestone targets of $35 \%$ by 1996 and $50 \%$ by the year 2000 (CCME 1998).

3R's approach is widely adopted across the GTA and within its municipalities. Although reduction of per capita generation of residential waste was $1.4 \%$ during the study period in the GTA, there was a different picture for individual Regions. Per capita residential waste generation increased by $1.3 \%$ for the Regional Municipality of Durham, $5.5 \%$ for the Regional Municipality of Halton and 3.3\% for the Region of Peel. Decrease of per capita residential waste generation was achieved by $5.5 \%$ and $4.7 \%$ by the Regional Municipality of York and by the City of Toronto respectively. Per capita waste generation rate is a good indicator for the effectiveness of source reduction initiatives. So, it deserves aggressive source reduction initiatives for the 
Regional Municipality of Durham, the Regional Municipality of Halton and for the Region of Peel, and more effective initiatives for the Regional Municipality of York and for the City of Toronto to augment the potential resources through this program.

\subsubsection{Recycling and Reuse}

Recycling is the process of separating useable raw materials from the waste stream with a view to returning them to the market. It is the second tier and another most effective step for reducing the waste load on landfills. It helps stretch the life spans of landfills and leads to significant reduction of GHG emissions. By removing the non-combustible materials such as, metals, glasses, etc., recycling can positively contribute to the performance of the incinerators and composting facilities as well.

In the GTA, majority waste is hauled every year to the landfills in Michigan from the Regional Municipalities as well as from the City of Toronto. Diversion from the landfills through recycling and reuse can greatly save the transportation cost for long distant places like Michigan as well as can help reduce pollution of the environment during the transportation of the waste material.

Benefits of recycling are manifold. In many cases, fresh raw materials can be replaced by recycled materials. So, recycling can help save limited and costly resources by reducing the requirement for augmentation of virgin materials. Consumption of energy for processing the recycled materials is normally less. So, recycling can help cut down the energy consumption and the associated cost of processing the fresh materials. Reuse of glass containers can save approximately $80 \%$ energy compared to producing new ones. Production of new aluminum items involves 25 times more energy consumption compared to using recycled aluminum for the same purpose. Use of scrap metals for production of steel can help reduce ore mining waste by $97 \%$, air pollution by $86 \%$ and water pollution by $76 \%$. Use of recycled paper for production of paper can reduce air pollution by $75 \%$ and water pollution by $35 \%$ compared to production of paper from trees. Recycled papers help save carbon sinks, the trees those would otherwise be required to harvest to produce the same amount of fresh paper. The Government of Canada has 
emphasized on the use of carbon sinks to offset GHG emissions and negotiated for the same at the international conference on climate change (Government of Canada 2002).

Diversion of residential waste through recycling and reuse programs in the City of Toronto increased from $16.6 \%$ of the waste generated in 2002 to $20.5 \%$ of that in 2008 . Diversion of residential waste through recycling and reuse programs in the Regional Municipality of York increased from $18.7 \%$ of the waste generated in 2002 to $25.7 \%$ of that in 2008 . Diversion of residential waste through recycling and reuse programs in the Regional Municipality of Durham increased from $21.1 \%$ of the waste generated in 2002 to $25.4 \%$ of that in 2008 . Diversion of residential waste through recycling and reuse programs in the Regional Municipality of Halton increased from $22 \%$ of the waste generated in 2002 to $28.3 \%$ of that in 2008 . Diversion of residential waste through recycling and reuse programs in the Regional Municipality of Peel decreased from $31.1 \%$ of the waste generated in 2002 to $29.9 \%$ of that in 2008 . But diversion through the same programs increased quantitatively by $16.7 \%$ in 2008 i.e. it was an increase from 123,943 tonnes in 2002 to 144,623 tonnes in the year 2008 for the Regional Municipality of Peel.

Stable markets and stable supply might be a precondition behind the success of recycling program. In addition to that, recycling programs must be made convenient to the residents/clients to help flourish it. Moreover, cultural change might be playing an important role in the country of immigrants like Canada so that consumers don't hesitate to purchase recycled products or products containing recycled contents. So, public education must be considered as a critical component to help make recycling and reuse program a success.

\subsubsection{Green bin SSO}

Diversion of organics and kitchen/food waste can greatly reduce the odour problems and prevents leachate formation in the landfills. It also helps in reduction of transportation cost as well as GHG emissions and extends the life of the landfills. No communities in the GTA have got organics diversion (Green Bin SSO) program in place. Only recently or a few years back this program has been introduced in most of the Regional municipalities. The Regional Municipality 
of Durham introduced this program in 2003, the Regional Municipality of Halton introduced this program in 2005, the Regional Municipality of Peel introduced this program in 2007 and the Regional Municipality of York introduced this program in 2004. Only the City of Toronto introduced this program in 2002. This program is not yet extended to multi-family houses. But already it has proved its potential by diverting significant amount of waste from landfills. In 2008 , this program alone diverted $11 \%$ of the total residential waste generated by the Regional Municipality of Durham, $8.6 \%$ of the total residential waste generated by the Regional Municipality of Halton, $6.2 \%$ of the total residential waste generated by the Regional Municipality of Peel, $26.08 \%$ of the total residential waste generated by the Regional Municipality of York and $10.6 \%$ of the total residential waste generated by the City of Toronto. In the year 2008, the contribution of the Green Bin SSO program was $11.9 \%$ of the total residential waste generated in the GTA. So, this program deserves development of effective strategies and comprehensive plans to implement at all levels including multi-family households to maximize augmentation of source separated organics.

\subsubsection{Biological Treatment}

Biological Treatment refers to decomposition of both organic wastes and non-recyclable paper fractions of the waste stream by the naturally occurring micro-organisms. Based on the objectives approach, Biological Treatment can be classified in to: $-(1)$ aerobic processing and (2) anaerobic processing.

\subsubsection{Aerobic Processing - Composting}

Aerobic Processing involves decomposition of organic wastes in the presence of oxygen to $\mathrm{CO}_{2}$ and compost product. Aerobic micro-organisms such as bacteria, actinomycetes and fungi play the vital role for decomposition. A constant supply of oxygen must be maintained to keep the micro-organisms active. In addition to the constant air supply, management of certain carbon to 
nitrogen $(\mathrm{C}: \mathrm{N})$ ratio $(25: 1-40: 1)$, moisture content (40-65\%), temperature $\left(130-160^{\circ} \mathrm{F}\right)$, and $\mathrm{pH}$ $(7-7.5)$ of the compost pile must be ensured to encourage activity of the micro-organisms.

Garden compost heap is the simplest form of composting which requires regular turning of the composting material in long piles or windrows. Forced aeration is the alternative open method of composting. Controlled composting includes different tower in vessel and horizontal in vessel methods.

Negligible amount of $\mathrm{CH}^{4}$ may be generated within the anaerobic zone of compost pile that must be oxidized as soon as it reaches the aerobic zone and finally before escaping to the surface air (EPA 2002a).

Composting helps reduce odour, fly and disease problems from the organic waste. It also helps in volume reduction by about $50 \%$. 1 tonne of municipal solid waste can produce about $300 \mathrm{~kg}$ to $500 \mathrm{~kg}$ of compost (Brunt et al. 1985). Moreover, relatively little capital investment is involved in composting.

Depending on the quality and the quantity of compost produced its use may be diversified. High quality compost is suitable for agriculture, horticulture, landscaping and home gardening. For erosion control and roadside landscaping medium quality compost may be used. Even low quality compost may be useful for landfill cover or in land reclamation projects. Although variable quantities of nutrients such as, nitrogen, phosphorus and potassium are present in compost yet their concentrations are lower than those of common fertilizers. Compost performs the functions of soil amendment or soil conditioner by supplying precious organic materials to the soil. Moreover, it improves soil quality by improving soil structure, aeration and water holding capacity.

In the Regional Municipality of Durham, diversion through different organics program increased from $7.1 \%$ of the total waste stream in 2002 to $21 \%$ of that in 2008 . In this Region, kitchen food waste composting program was introduced along with otber organics program in 2003 . In the Regional Municipality of Haiton, diversion through different organics program increased from $11.2 \%$ of the total waste stream in 2002 to $24.06 \%$ of that in 2008 . In this Region, green cart/kitchen food waste composting program was introduced along with other organics program 
in 2005. In the Regional Municipality of Peel, diversion through different organics program increased from $8.83 \%$ of the total waste stream in 2002 to $17.1 \%$ of that in 2008 . In this Region, separate organics program was introduced along with other organics program in 2007. In the Regional Municipality of York, diversion through different organics program increased from $5.1 \%$ of the total waste stream in 2002 to $37.08 \%$ of that in 2008 . In this Region, source separated organics program was introduced along with other organics program in 2004 . In the City of Toronto, diversion through different organics program increased from $8.2 \%$ of the total waste stream in 2002 to $20 \%$ of that in 2008. In this City, green bin SSO program was introduced along with other organics program in 2002. Significant increase of organics diversion throughout the study period in the GTA indicates increasing potential for composting. In the year 2008, about $64 \%$ of the total organics in addition to the backyard composting were processed by different aerobic facilities operating across the GTA.

\subsubsection{Anaerobic Processing - Bio-energy}

Alternative to aerobic composting that may be employed for organic waste management is the anaerobic processing. It is the decomposition process which takes place in the absence of oxygen and the decomposition of waste is carried out by the anaerobic micro-organisms. Anaerobic processing produces $\mathrm{CH}_{4}$ gas that can be used as energy or used in gas-engine generators to produce electricity. The organic residue of the anaerobic digestion process can be used as compost, soil-improver, fertilizer, filler, filter material, landfill cover, etc. $\mathrm{CO}_{2}$ emissions by this process are not counted in the national GHG inventories.

In comparison to aerobic processing, anaerobic processing of organic waste is rather complicated and addresses some additional technical issues such as gas collection, leachate collection and treatment. It involves relatively large capital investment but it can handle larger volume of organic waste. Moreover, it can generate renewable energy and feed electricity to the national grid.

Two anaerobic digestions of organic waste and energy generation plants have already been set up and operated by Canada in the GTA. The Canada Composting Inc. (CCI) plant was built in 2000 
and is located at Newmarket, Ontario. This plant uses the BTA process developed in Germany (CCI 2000). It can accommodate 150,000 tonnes of waste per year (NOPP 2003b). In 2004, the facility has been owned by Halton Recycling Ltd. The equipment was retrofitted and a composting plant was installed on site by the company. 100 to 150 tonnes/day of source separated organics from Green Bin programs in Toronto and the York Region are processed by the facility. Halton can supply up to 77,000 tonnes/year of source separated organics under an agreement with the City of Toronto. Its design / processing capacity is 400 metric tonnes per day. The Caterpillar cogeneration equipment can generate about 1,640 KWh of electricity which is used to operate the plant. Excess electricity if any is sold to the local utility. Another similar plant using the BTA process is established in Toronto at Dufferin solid waste transfer station. This plant can process 25,000 tonnes of source separated organics per year (BTA \& Co KG 2003). It is operated by Canada composting, Inc. under a contract. On an average, 100 metric tonnes per day of SSO is processed by this facility. $110 \mathrm{~m}^{3}$ of biogas per metric tonne of SSO is generated by the digester. Both of theses plants are performing significantly well.

\subsubsection{Incineration}

High temperature burning of municipal solid waste in the incinerator can recover energy either in the form of steam or electricity. Incineration can dramatically reduce the amount of waste requiring disposal by approximately $70 \%$. Stabilisation of waste can be achieved by incineration, mainly due to the oxidation of the organic components. Incineration of clinical waste and municipal solid waste (MSW) ensures destruction of pathogens prior to final disposal in the landfills.

An Energy from Waste (EFW) facility is Located at Brampton for the disposal of municipal solid waste. The plant was commissioned in 1992 and the original cost of the plant was $\$ 50$ million. The plant is now owned and operated by Algonquin Power Systems Inc. About $93 \%$ of the municipal solid waste processed here is residential waste and is supplied by the Regional Municipality of Peel under a 20-year contract. International air port waste and industrial, commercial and institutional (IC\&I) waste comprises of the remaining portion of the waste 
processed here. In the year $2008,99,246$ tonnes of residential waste was sent to this facility by the Regional Municipality of Peel. Approximately 500 tonnes of municipal solid waste is incinerated each day here. The facility can generate a maximum of fifteen megawatts of electrical energy and its yearly generation is enough to power up to about 6000 homes. It also feeds electricity to the grid and sells to Ontario Power Generation. In the year 2006, 42,091 megawatts hour (MWh) of electricity was sold to the Ontario Power Generation.

The Air Pollution Control (APC) system of the facility ensures emissions well below the provincial standards. The APC system consists of : a wet-spray humidifier to cool and humidify flue gases; a venture dry lime injection tower to remove acidic gases; a powered activated carbon (PAC) injection system to reduce mercury; a baghouse filtering system to remove particulate and selective catalytic reduction (SCR) reactor to reduce the Nitrous Oxide emissions, dioxins and furans. Hazardous fly ash is collected from the baghouse filtering system and is disposed of at a secure hazardous waste landfill site in Quebec. After separating the ferrous material from the bottom ash, it is then screened into two size groups. Bottom ash is mostly used as landfill daily cover. Other potential uses of processed bottom ash are as asphalt and as a substitute for aggregates.

Emission of toxic pollutants such as dioxins, furans, etc. from incineration is of concern to the communities across Canada. Even a ban was announced on the construction of incinerators by the Ontario's Environment Minister in 1991. Dioxin emitted by incineration is of concern to Health Canada as they believe Dioxin to be the cause of cancer. Moreover, it's an expensive option.

\subsubsection{Landfilling}

Landfilling is the oldest and the widely used method of disposing waste around the world and so is with Canada and the GTA. Leachate and landfill gases from the landfills that contaminate ground water, surface water and air are of great environmental concern and responsible for the climate change. With the passage of time, it has been improved from simple dumping to sanitary landfilling. Sanitary landfills are designed, operated and maintained following the standard 
engineering procedures with a view to minimizing public health and environmental impact. It consists of gas control systems, liners, leachate collection and treatment systems, and extensive groundwater monitoring system. Constructions of landfills are now controlled by the federal/provincial rules and regulations like siting regulations and others.

Modern sanitary landfills are known as bioreactor landfills in which leachate is circulated to enhance stabilisation of the biodegradable waste materials. Aerobic bioreactors require less than two years for full stabilisation of biodegradable waste material. Anaerobic bioreactors help increase the amount of methane gas production by leachate circulation and facilitate capturing as well as converting the gas to electricity. Bioreactors decrease the long term liability and monitoring costs. But bioreactor landfilling is still in the research stage.

In the GTA, disposal of residential waste decreased from 1,317,923 tonnes in 2002 to $1,067,054$ tonnes in 2008. Waste disposal decreased by $19 \%$ from 2002 to 2008 . Except the amount sent to the Energy from Waste (EFW) facility at Brampton, remaining all residential waste was disposed of either in the local landfills or the landfill at Michigan. But majority of the waste was sent to the landfill at Michigan.

The Keele valley landfill (located at Vaughn, York Region boundary), owned by the City of Toronto but also was used by the York Region was closed in 2002. The Keele valley landfill site was also used by the Regional Municipality of Durham. The Britania landfill site used by the Region of Peel was also closed in 2002. So, disposal of waste turned to an acute problem for the GTA. Attempts were made by the authorities to find suitable locations for landfills within the respective Regional boundaries, but the mission became totally unsuccessful at the face of very strong opposition by the residents to accept new landfills in their community. Since then i.e. from the year 2002, majority wastes from the GTA were started hauling to Michigan under a contract which would be expired at the end of 2010. Regional Municipality of Halton has got its own landfill within its boundary that has got an active life up to the year 2030. Purchase of the Green Lane landfill provides City of Toronto with disposal security within Ontario borders. The other three Regional Municipalities must have to look for alternative solutions to their disposal problems. 
Sanitary Landfills provide an opportunity for capturing landfill gases that can be captured and converted to energy or electricity to feed the national grid where it is feasible. The Keele Valley landfill site generates $274,800,000 \mathrm{KWh}$ or power for roughly 24,000 homes and the Brock West landfill site generates $43,500,000 \mathrm{KWh}$ or power for roughly 3,800 homes.

It takes approximately 100 years for the complete stabilisation of the wastes in the landfills. So, it involves a huge expenditure for maintenance. Moreover, it occupies large area for the operation of the facility.

In the year 2005, waste sector emitted $3.7 \%$ GHG of the total emissions by Canada. $\mathrm{CH}_{4}$ emissions from the Solid Waste Disposal on Land subsector accounted for $96 \%$ of the emissions from this sector. It indicates landfills to be the major contributors for GHG emission in Canada. 


\section{CHAPTER 6}

\section{CONCLUSIONS AND RECOMMENDATIONS}

\subsection{Conclusions}

With the increasing quantity of residential waste, Greater Toronto Area (GTA) is in the crisis of landfill disposal facilities for many years. So, majority of its waste is hauled to Michigan under an agreement which is going to be expired by the year 2010. It is not the space problem but strong opposition from the residents to accept landfills close to their community prevented the GTA from constructing new landfills.

Approximately $45 \%$ of the total waste generated in the GTA in 2008 was landfilled and majority portion was hauled to Michigan. $96 \%$ of the total GHG emissions by the waste sector is attributed to Landfill gas. In the landfills, decomposition of waste produces landfill gas which is primarily composed of $\mathrm{CH}_{4}$, a greenhouse gas liable for climate change. This landfill gas can be converted to potential energy source to generate electricity, fuel industries and heat buildings. Landfill gas/biogas is considered to be one of the renewable energy generation sources by the Ontario Power Authority. Landfills occupy large areas, take longest time for complete stabilisation of waste and involve huge expenditure for maintenance.

Source reduction can play a vital role in waste management by reducing the waste from the waste stream without involving additional materials, energy, manufacturing cost, transporting cost and landfill space. Finally, it helps reduce the green house gas (GHG) emissions from the landfills. Positive impact of source reduction is reflected well in the per capita waste generation trend of the City of Toronto and the Regional Municipality of York individually and the GTA as a whole.

Recycling and reuse can greatly impact on the reduction of waste before entering into the treatment option/disposal facility. It involves significantly less material, less energy and less manufacturing cost compared to new products. It helps save landfill space and extends the life of 
landfills and ultimately helps reduce the GHG emissions from the landfills. Impact of recycling and reuse option was reflected well during the study period throughout the Greater Toronto Area.

Diversion of organics and kitchen/food waste can greatly reduce the odour, prevents leachate formation as well as GHG emissions and help extend the life of the landfills. Diversion of residential waste through different organics program including green bin SSO performed remarkably well during the study period throughout the Greater Toronto Area, although the green bin SSO program was not introduced since the beginning of the study period in most of the Regions. Moreover, green bin SSO program is yet to be extended in the multi-family households. So, green bin SSO program of waste diversion seems to be a highly potential one.

Aerobic processing of organics helps prevent GHG emissions with the output as compost. Greater portion (64\%) of the organics collected in the GTA in 2008 was aerobically processed in different aerobic processing facilities to produce compost.

Anaerobic processing of source separated organics (SSO) can potentially produce biogas and significantly contribute towards greenhouse gas emissions reduction and renewable energy procurement. The two anaerobic digestion plants processed $36 \%$ of the organics collected in the GTA in 2008 and produced bio-fuel and electricity.

Utilization of total potential from the source reduction, recycling and reuse, and green bin SSO programs can lead to conceiving zero waste disposal goal in the long term.

Incinerators are relatively common and widely used in Europe and Japan. Although incinerators are not so common in Canada, yet one incinerator using energy from waste technology is in operation in the GTA. Approximately 5\% of the total waste generated in the GTA in 2008 was sent to this facility. Its generated electricity is fed to the grid. It's also an expensive technology. Dioxin emitted by incineration is of concern to Health Canada as they believe Dioxin to be the cause of cancer.

Life cycle study models and optimisation models can be used for decision making processes regarding the integration of waste management options to achieve an effective and sustainable solution to the waste management problems. 
Success of waste management efforts depend on the all out sustainability of the integrated waste management approaches. Each of the waste management options comprising the integrated waste management approach must be economically viable, technically feasible in the aspect of environmental protection, and socially and politically acceptable.

Integrated waste management comprising of source reduction, recycling and reuse, diversion through green bin SSO program and the aerobic processing of organic waste treatment can be a short term approach. Integrated waste management comprising of source reduction, recycling and reuse, diversion through green bin SSO program and the anaerobic processing of organic waste treatment can be a long term approach.

With a view to achieving sustainability for individual options as well as the integrated waste management system as a whole community involvement through their participation and support is a major concern. So, communication strategies and effective public education programs needs to be expedited. 


\subsection{Recommendations}

Considering the limitations and potential for different waste management options, following recommendations are drawn for the Greater Toronto Area:

Reasonable targets for waste diversion not only on the basis of percentage but also on the basis of per capita can be set and a comprehensive plan can be developed to reduce, recycle and reuse waste products with the theme of zero waste disposals.

Strategies should be developed and effective actions should be undertaken for utilizing the maximum potential of reducing wastes before generation and the stake holders should be committed to this effect.

Recycling and reuse programs should be extended to all households (single family/multi-family) to maximize augmentation of diversion potential of wastes.

Source separated organics program should be implemented in full scale covering all households (single family/multi-family) to maximize augmentation of diversion potential of organics wastes.

Integrated waste management comprising of source reduction, recycling and reuse, diversion through green.bin SSO program and the aerobic processing of organic waste treatment can be a short term approach. Integrated waste management comprising of source reduction, recycling and reuse, diversion through green bin SSO program and the anaerobic processing of organic waste treatment with cogeneration facility can be a long term approach. These two approaches should be considered as the most effective and sustainable solution to the residential waste management problems in the GTA.

Effective steps should be undertaken to capture landfill gas from the closed landfills and to convert it to energy/electricity to offset the national energy needs, where feasible and no actions have yet been taken.

Regulatory and financial support should be ensured in order to implement the sustainable waste management systems in the GTA. 
Aggressive communication strategies and effective public education programs should be developed and implemented to ensure active community participation with a view to achieving sustainability for individual options as well as the integrated waste management system as a whole.

Location specific and needs based continued research should be carried out to develop innovative technologies for efficient and cost-effective treatment and disposal of wastes ensuring sustainability of the systems. 


\section{REFERENCES}

Asase, M., Yanful, E.K., Mensah, M., Stanford, J., and Amponsah, S. 2009. Comparison of Municipal Solid Waste Management Systems in Canada and Ghana: A Case Study of the Cities of London, Ontario, and Kumasi, Ghana. Waste Management, v 29, issue 10, p 2779-2786

Ayalon, O., Avnimelech, Y., and Shechter, M. 2001. Solid waste Treatment as a High-Priority and Low-Cost Alternative for Greenhouse Gas Mitigation. Environmental Management, v 27, issue $5, \mathrm{p}$ 697-704

Benson, C.H., Barlaz, M.A., Lane, D.T., and Rawe, J.M. 2006. Practice Review of Five Bioreactor/Landfills. Waste management 27 (2007) 13-29

Brunt, L.P., Dean, R.B., and Patrick, P.K., 1985. Composting. Solid Waste management. World Health Organization, Geneva, Switzerland. pp 70-75

BTA \& Co KG, 2003. BTA Demonstration Plant in Toronto. BTA \& Co KG, Munich, Germany Canadian Council of Ministers of the Environment, 1998. National Packaging Protocol 1996 Milestone Report

Cabaraban, M.T.I., Khire, M.V., and Alociljia, E.C. 2008. Aerobic In-vessel Composting versus Bioreactor Landfillin Using Life cycle Inventory Models. Clean Technologies and Environmental Policy, v 10, issue 1, p 39-52

Calabro, P.S. 2009. Greenhouse Gases Emission from Municipal Waste Management: The Role of Separate Collection. Waste Management, v 29, issue 7, p 2178-2187

Canadian Council of Ministers of the Environment, 2009. Canada - Wide Action Plan For the Extended Producer Responsibility 
CCI (Canada Composting Inc.), 2000. CCI Newmarket Plant, Canada Composting Inc., Newmarket, Ontario

Chang, S.Y., and Nishat, S. 2005. Integrated Solid Waste Management for the City of Greensboro, NC: A Linear Programming Model. Journal of Solid Waste Technology and Management, v 31, issue 4, p 169-186

Chen, T.C., and Lin, C.F. 2008. Greenhouse Gases Emissions from Waste Management Practices Using Life Cycle Inventory Model. Journal of Hazardous Materials, v 155, issue 1-2, p 23-31.

City of Toronto. 2005. Multi-Year Business plan

City of Toronto. 2006. 2005 Residential Waste Resources Diversion Rate

City of Toronto. 2006. 2006 Annual Financial Report

City of Toronto. 2008. 2008 Annual Financial Report

City of Toronto. 2009. 2007 Performance Measurement and Benchmarking Report

Environment Canada. 2007. National Inventory Report: Greenhouse Gas Sources and Sinks in Canada, 1990-2006. Environment Canada. 2007. Website http://www.ec.gc.ca/pdb/ghg/inventory_report/2006_report/s2_eng.cfm Environment Canada. 2007. Waste Management. Keele Valley Project. Website http://www.ec.gc.ca/drgd-wrmd/default.asp?lang=En\&n=DC0D6323-1

Environment Canada. 2007. Waste Management. Brock West Project. Website http://www.ec.gc.ca/drgd-wrmd/default.asp?lang=En\&n=B81863DD-1

Environment Canada. 2007. Waste Management. Thermal Unit. Website http://www.ec.gc.ca/drgd-wrmd/default.asp?lang=En\&n=34737E0-1\&toc=show

EPA (United States Environmental Protection Agency). 2002a. Solid Waste management and Greenhouse Gases - A Life Cycle Assessment of Emission and Sinks 
EPA (United States Environmental Protection Agency). 2002d. Municipal Solid Waste-Source Reduction and Reuse. US Environmental Protection Agency, Washington, D.C.

Gartner Lee Limited, 2008. Region of Peel Long Term Waste management Strategy Update: Draft Final Report

Gentil, E., Clavreul, J., and Christensen, T.H. 2009. Global Warming Factor of Municipal Solid Waste Management in Europe. Waste Management and Research, v 27, issue 9, p 850-860

Goldstein, N. 2005. Source Separated Organics as a Feedstock for Digesters. Biocycle, v 46, issue $8, \mathrm{p} 42-46$.

Hickman, H.L.Jr. 1999. Principles of Integrated Solid Waste Management. American Academy of Environmental Engineers, United States of America.

Karagiannidis, A., and Perkoulidis, G. 2009. A Multi-Criteria Ranking of Different Technologies for the Anaerobic Digestion for Energy Recovery of the Organic Fraction of Municipal Solid Wastes. Bioresource Technology, v 100, issue 8, p 2355-2360

Kelleher Environmental. 2009. Research on Behaviour Change

Kerith, F. 1994. Handbook of Solid Waste Management. McGraw-Hill, Inc. United States of America.

Khoo, H.H., Lim, T.Z., and Tan, R.B.H. 2010. Food Waste Conversion Options in Singapore: Environmental Impacts based on an LCA Perspective. Science of the Total Environment, v 408, issue $6, \mathrm{p} 1367-1373$

Lou, X.F., and Nair, J. 2009. The Impact of Landfilling and Composting on greenhouse gas Emissions - A Review. Bioresource Technology, v 100, issue 16, p 3792-3798

Malakahmad, A., Ahmad, B.N., and Zain, S.M. 2008. An application of Anaerobic Baffled Recator to Produce Biogas from Kitchen waste. WTT Transactions on Ecology and the Environment, v 109, p 655-664. 
Mbuligwe, S.E., and Kassenga G.R. 2004. Feasibility and strategies for Anaerobic Digestion of Solid Waste for Energy Production in Dar es Salam City, Tanzania. Resources, Conservation and Recycling, $\mathrm{v} 42$, issue $2, \mathrm{p} 183-203$

McDougall, F., White, P. R., Franke, M., and Hindle, P. 2001. Integrated Solid Waste Management: a Life cycle Inventory, Second Edition. Blackwell Science, Inc., 350 Main street, Malden, MA 02148 5018, USA

Mohareb, A.K., Warith, M., and Narbaitz, R.M. 2004. Strategies for the Municipal Solid Waste Sector to Assist Canada in Meeting its Kyoto Protocol Commitments. Environmental Reviews, v 12 , issue $2, \mathrm{p} 71-95$.

Mohareb, A.K., Warith, M., and Diaz, R. 2008. Modelling Greenhouse Gas Emissions for Municipal Solid Waste Management Strategies in Ottawa, Ontario, Canada. Resources, Conservation and Recycling, v 52, issue 11, p 1241-1251.

Ngnikam, E., Tanawa, E., Rousseaux, P., Riedacker, A., and Gourdon, R. 2002. Evaluation of the Potentialities to Reduce Greenhouse Gases (GHG) Emissions Resulting from Various Treatments of Municipal Solid Wastes (MSW) in Moist Tropical Climates: Application to Yaounde. Waste Management and Research, v 20, issue 6, p 501-513.

NOPP (National Office of Pollution Prevention), 2003a. Landfill Gas - CCI - Anaerobic Waste Digestion. Technical bulletins, National Office of Pollution Prevention, Environment Canada, Ottawa, Ontario

NOPP (National Office of Pollution Prevention), 2003b. Landfill Gas - SUBBOR Pilot Waste Processing Project. Technical bulletins, National Office of Pollution Prevention, Environment Canada, Ottawa, Ontario

Papachristou, E., Hadjianghelou, H., Darakas, E., Alivanis, K., Belou, A., Ioannidou, D., Paraskevopoulou, E., poulios, k., Koukourikou, A., Kosmidou, N., and Sortikos, K. 2009. Perspectives for Integrated Municipal Solid Waste Management in Thessaloniki, Greece. Waste Management, v 29, issue 3, p 1158-1162 
Pichtel, J. 2005. Waste Management Practices. Municipal, Hazardous, and Industrial. Taylor \& Francis group, 6000 Broken Sound Parkway NW, Boca Raton, FL 33487-2742

Region of Durham, 1999. Long Term Waste Management Strategy Plan: 2000 to 2020

Regional Municipality of Durham, 2003-2009. Waste Management Annual Reports 2002-2008

Regional Municipality of Durham, 2006. 2006 Annual Report

Regional Municipality of Durham, 2008. 2008 Annual Report

Regional Municipality of Halton, 2003. 2002 Year End Waste Management Tonnage Report

Regional Municipality of Halton, 2004. 2003 Waste Management Update

Regional Municipality of Halton, 2005-2009. Year End Waste Management Tonnage Reports 2004-2008.

Region of Peel, 2003-2005. Long Term Waste Resource Management Strategies 2002-2004

Region of Peel, 2006. 2005 Waste Diversion Update

Region of Peel, 2007-2009. Residential Waste Stream Diversions

Region of Peel; 2008. Long Term Waste Management Strategy Update: Draft Final Report

Region of Peel, 2003. 2003 Annual Financial Report

Region of Peel, 2008. 2008 Annual Financial Report

Schiffler, H. 2002. The Closed Cycle - Economy in Figures [online]. Duales system deutchland AG, Kロln, Grmany.

Smith, S.R., and Jasim, S. 2009. Small-Scale Home Composting of Biodegradable Household Waste: Overview of Key Results from a 3 - Year Research Programme in West London. Waste Management and Research, $\vee 27$, issue10, p 941-950

Statistics Canada. 2008. Disposal and diversion of waste, by province and territory, (Total waste disposal), 2004 and 2006. Website http://wwww40.statcan.ca/101/cst01/envir32a-eng.htm 
Statistics Canada. 2008. Disposal and diversion of waste, by province and territory, (Total materials diverted), 2004 and 2006. Website http://wwww40.statcan.ca/101/cst01/envir32ceng.htm

Statistics Canada. 2008. Population and dwelling counts, for Canada, provinces and territories, 2006 and 2001 census $-100 \%$ data

Statistics Canada. 2010. Births and birth rate, by province and territory. Website http://wwww40.statcan.ca/101/cst01/demo046-eng.htm

Tinmaz, E., and Demir, I. 2006. Research on Solid Waste Management System: To Improve Existing Situation in Corlu Town of Turkey. Waste Management, v 26, issue 3, p 307-314

Toronto City Summit Alliance. 2008. Greening Greater Toronto

Valencia, R., Zon, W.V., Woelders, H., Lubberding, H. J., and Gijzen, H.J. 2009. Achieving Final Storage Quality of Municipal Solid Waste in Pilot Scale Bioreactor Landfills. Waste Management, $\mathrm{v} 29$, issue 1, p 78-85.

Warith, M. 2002. Bioreactor Landfills: Experimental and Field results. Waste Management, v 22, issue $1, \mathrm{p} 7-17$

Warith, M., and Steven, L. 2005. Effect of Leachate Recirculation on Bioreactor landfills Performance. Proceedings, Annual Conference - Canadian Society for Civil Engineering, v 2005, p EV-114-1-EV-114-9

York Region, 2006. Joint Waste Diversion Strategy

York Region, 2009. Interim Environmental Assessment (EA) Study Document

Zamorano, M., Brebbia, C.A., Kungolos, A.G., Popov, V., and Itoh, H. 2008. Waste

Management and the Environment IV. WIT Press, Ashurst Lodge, Ashurst, Southampton, SO40 7AA, UK

Zhao, W., Voet, E., Zhang, Y., and Huppes, G. 2009. Life Cycle Assessment of Municipal Solid Waste Management with Regard to Greenhouse Gas Emissions: Case Study of Tianjin, China. Science of the Total Environment, $\mathrm{v} 407$, issue 5, p 1517-1526. 
http://www.toronto.ca/garbage/pdf/2006_div-breakdownchart.pdf http://www.toronto.ca/garbage/pdf/2007-chart.pdf http://www.toronto.ca/garbage/pdf/2008-chart.pdf http://en.wikipedia.org/wiki/Greater_Toronto_Area 
APPENDICES 


\section{APPENDIX-A}

Regional Municipality of Durham

Residential Waste Management (2002-2008)

\begin{tabular}{|l|c|c|c|c|c|c|c|c|}
\hline Year & 2002 & 2003 & 2004 & \multicolumn{2}{c|}{2005} & 2006 & 2007 & 2008 \\
\hline \multicolumn{7}{|c|}{ Waste Landfilled (Tonnes) } \\
\hline Curbside and multi-residential waste collection & 131,516 & 129,922 & 131,785 & 131,882 & 114,800 & 96,442 & 96,803 \\
\hline Waste collected at Regional waste disposal sites & 14,236 & 15,015 & 17,639 & 16,827 & 19,045 & 19,844 & 19,661 \\
\hline Total Waste Landfilled & 145,752 & 144,937 & 149,424 & 148,709 & 133,845 & 116,286 & 116,464 \\
\hline & Waste Diverted (Tonnes) & & & \\
\hline Curbside \& Apartment Recycling & 37,738 & 39,122 & 44,099 & 47,056 & 55,511 & 55,485 & 53,967 \\
\hline Leaf \& Yard Waste Composting & 14,648 & 16,000 & 16,407 & 18,337 & 20,490 & 19,407 & 23,753 \\
\hline Food Composting & 0 & 2,519 & 2,839 & 2,883 & 13,976 & 26,211 & 25,907 \\
\hline Reuse Programs & 5,757 & 6,049 & 6,247 & 6,295 & 6,752 & 6,618 & 5,591 \\
\hline Grass Cycling \& Composting credit & 2,260 & 1,230 & 2,802 & 8,746 & 9,139 & 8,950 & 9,908 \\
\hline Total Waste Diverted & 60,403 & 64,920 & 72,394 & 83,317 & 105,868 & 116,671 & 119,126 \\
\hline Total Waste Managfd Tounes) & 206,155 & 209,857 & 221,818 & 232,026 & 239,713 & 232,957 & 235,590 \\
\hline
\end{tabular}

Source: Regional Municipality of Durham (2003-2009) 


\section{Regional Municipality of Halton}

\section{Residential Waste Management (2002-2008)}

\begin{tabular}{|c|c|c|c|c|c|c|c|}
\hline Year & 2002 & 2003 & 2004 & 2005 & 2006 & 2007 & 2008 \\
\hline \multicolumn{8}{|c|}{ Waste Landfilled (Tonnes) } \\
\hline Residential Waste & 85,984 & 89,924 & 93,559 & 94,298 & 98,679 & 95,869 & 70,589 \\
\hline Rural Waste & 0 & 0 & 2,135 & 2,346 & 1,921 & 1,966 & 482 \\
\hline Multi-Unit Front End Waste & 4,922 & 5,186 & 5,181 & 4,281 & 5,038 & 5,083 & 4,989 \\
\hline Container Station: Waste & 9,656 & 10,172 & 10,426 & 10,336 & 11,284 & 11,114 & 11,633 \\
\hline Residential Tipping Face Waste & 0 & 0 & 0 & 880 & 1,567 & 3,921 & 749 \\
\hline Halton Recycling Residential Waste & 1,368 & 1,701 & 1,914 & 2,076 & 1,932 & 2,315 & 4,333 \\
\hline Total Waste Landfilled & 101,930 & 106,983 & 113,215 & 114,217 & 120,421 & 120,268 & 92,775 \\
\hline \multicolumn{8}{|c|}{ Waste Diverted (Tonnes) } \\
\hline Curbside \& Multi-Unit Blue Box and Igloo Depot & 32,354 & 34,625 & 38,143 & 40,396 & 43,149 & 41,258 & 46,868 \\
\hline Material Reuse & 4,851 & 5,709 & 8.973 & 11,218 & 13,016 & 13,728 & 13,650 \\
\hline Leaf, Yard Waste \& Bush & 18,839 & 22,581 & 21,874 & 21,367 & 25,855 & 21,289 & 32,804 \\
\hline Grasscycling \& Backyard Composting & 10,566 & 10,864 & 11,195 & 11,506 & 8,717 & 8,934 & 9,115 \\
\hline Kitchen/Green Cart Organics & 0 & 0 & 0 & 95 & 312 & 229 & 18,421 \\
\hline Christmas Trees & 302 & 319 & 354 & 354 & 347 & 411 & 343 \\
\hline Total Waste Diverted & 66,912 & 74,098 & 80,539 & 84,936 & 91,396 & 85,849 & 121,201 \\
\hline Total Waste Managed (Tonnes) & 168,842 & 181,081 & 193,754 & 199153 & 211,817 & 206,117 & 213,976 \\
\hline
\end{tabular}

Source: Regional Municipality of Halton (2003-2009) 


\section{APPENDIX-C}

\section{Regional Municipality of Peel}

Residential Waste Management (2002-2008)

\begin{tabular}{|l|c|c|c|c|c|c|c|c|}
\hline Year & 2002 & 2003 & 2004 & 2005 & 2006 & 2007 & 2008 \\
\hline \multicolumn{7}{|c|}{ Waste Disposed (Tonnes) } \\
\hline Landfilled & 61,869 & 20,277 & 21,570 & 15,075 & 11,746 & 19,693 & 31,024 \\
\hline Exported & 43,584 & 83,372 & 102,707 & 121,145 & 133,968 & 120,336 & 109,733 \\
\hline Energy from Waste & 114,589 & 121,328 & 110,560 & 106,279 & 111,193 & 84,492 & 99,246 \\
\hline \multicolumn{1}{|c|}{ Total Waste Disposed } & 220,312 & 224,977 & 234,837 & 242,499 & 256,907 & 224,521 & 240,003 \\
\hline \multicolumn{2}{|c|}{ Waste Diverted (Tonnes) } & & \\
\hline Recycling & 85,111 & 89,715 & 98,074 & 104,055 & 116,879 & 104,808 & 108,253 \\
\hline Material Reuse & 38,832 & 38,587 & 39,251 & 36,104 & 34,065 & 35,536 & 36,370 \\
\hline Leaf, Yard WastelOrganics & 35,175 & 43,388 & 42,104 & 45,299 & 46,636 & 40,738 & 52,425 \\
\hline Organics & 0 & 0 & 0 & 0 & 0 & 24,468 & 30,070 \\
\hline Grasscycling and Backyard Composting & 18,902 & 14,029 & 14,526 & 14,342 & 14,611 & 15,111 & 15,172 \\
\hline Total Waste Diverted & 178,020 & 185,719 & 193,955 & 199,800 & 212,191 & 220,661 & 242,290 \\
\hline Total Waste Mavaged & 398,332 & 410,696 & 428,792 & 442,299 & 469,098 & 445,182 & 482,293 \\
\hline
\end{tabular}

Source: Regional Municipality of Peel (2003-2009) 


\section{APPENDIX-D}

\section{Regional Municipality of York}

\section{Residential Waste Management (2002-2008)}

\begin{tabular}{|l|c|c|c|c|c|c|c|c|}
\hline Year & 2002 & 2003 & 2004 & 2005 & 2006 & 2007 & 2008 \\
\hline \multicolumn{7}{|c|}{ Waste Disposed (Tonnes) } \\
\hline Residential Waste (Garbage) Collection & 208,534 & 222,427 & 226,901 & 209,502 & 191,966 & 145,918 & 115,115 \\
\hline Blue Box (residue to landfill) & 1,952 & 2,115 & 1,797 & 3,490 & 5,998 & 6,413 & 8,158 \\
\hline Total Waste Landfilled & 210,486 & 224,542 & 228,698 & 212,992 & 197,964 & 152,331 & 123,273 \\
\hline \multicolumn{7}{|c|}{ Waste Diverted (Tonnes) } & & \\
\hline Recycling & 49,724 & 51,265 & 55,761 & 61,568 & 71,733 & 74,865 & 81,277 \\
\hline Material Reuse & 1,793 & 2,294 & 2,464 & 2,985 & 3,573 & 3,520 & 3,539 \\
\hline Source Separated Organics & 0 & 0 & 849 & 12,080 & 24,809 & 60,290 & 86,266 \\
\hline Yard Waste & 14,084 & 19,937 & 22,772 & 24,493 & 28,739 & 28,359 & 36,374 \\
\hline Total Waste Diverted & 65,601 & 73,496 & 81,846 & 101,128 & 128,854 & 167,034 & 207,456 \\
\hline Total Waste Managed (Tonnes) & 276,087 & 298,038 & 310,544 & 314,120 & 326,818 & 319,365 & 330,729 \\
\hline
\end{tabular}

Source : Regional Municipality of York (2009) 


\section{APPENDIX-E}

\section{City of Toronto}

\section{Residential Waste Management (2002-2008)}

\begin{tabular}{|c|c|c|c|c|c|c|c|}
\hline Year & 2002 & 2003 & 2004 & 2005 & 2006 & 2007 & 2008 \\
\hline \multicolumn{8}{|c|}{ Waste Disposed (Tonnes) } \\
\hline Single Family Residential & & & & 270,444 & 247,601 & 226,787 & 238,363 \\
\hline Multi-family Residential & & & & 257,434 & 261,802 & 271,022 & 256,176 \\
\hline Total Waste Disposed & 639,443 & 621,332 & 565,910 & 527,878 & 509,403 & 497,809 & 494,539 \\
\hline \multicolumn{8}{|c|}{ Waste Diverted (Tonnes) } \\
\hline Blue/Grey Box Recycling & 134,623 & 143,853 & 147,936 & 158,116 & 163,385 & 154,799 & 158,747 \\
\hline Leaf \& Yaed Waste and Xmas Trees & 69,778 & 78,598 & 80,069 & 81,574 & 80,069 & 77,509 & 82,766 \\
\hline Material Reuse & 12,106 & 12,634 & 16,386 & 15,791 & 14,428 & 19,483 & 21,650 \\
\hline Grasscycling and Backyard Composting & 27,876 & 29,821 & 29,959 & 30,396 & 30,234 & 29,948 & 30,824 \\
\hline Green Bin SSO & 2,976 & 21,929 & 35,808 & 60,273 & 87,505 & 85,552 & 94,201 \\
\hline Total Waste Diverted & 247,359 & 286,835 & 310,158 & 346,150 & 375,621 & 367,291 & 388,188 \\
\hline Total Waste Managed (Tonnes) & 886,802 & 908,157 & 876,068 & 874,028 & 885,024 & 865,100 & 882,727 \\
\hline
\end{tabular}

Source: Kelleher Environmental (2009), City of Toronto (2006-2008) 